\title{
WestVirginiaUniversity
}

THE RESEARCH REPOSITORY @ WVU

Graduate Theses, Dissertations, and Problem Reports

2013

\section{Compositional Techniques in Hodie by Ralph Vaughan Williams}

\author{
Ah Reum Han \\ West Virginia University
}

Follow this and additional works at: https://researchrepository.wvu.edu/etd

\section{Recommended Citation}

Han, Ah Reum, "Compositional Techniques in Hodie by Ralph Vaughan Williams" (2013). Graduate Theses, Dissertations, and Problem Reports. 397.

https://researchrepository.wvu.edu/etd/397

This Dissertation is protected by copyright and/or related rights. It has been brought to you by the The Research Repository @ WVU with permission from the rights-holder(s). You are free to use this Dissertation in any way that is permitted by the copyright and related rights legislation that applies to your use. For other uses you must obtain permission from the rights-holder(s) directly, unless additional rights are indicated by a Creative Commons license in the record and/ or on the work itself. This Dissertation has been accepted for inclusion in WVU Graduate Theses, Dissertations, and Problem Reports collection by an authorized administrator of The Research Repository @ WVU.

For more information, please contact researchrepository@mail.wvu.edu. 


\title{
Compositional Techniques in Hodie by Ralph Vaughan Williams
}

\author{
Ah Reum Han \\ Research Project submitted to the \\ College of Creative Arts \\ at West Virginia University \\ in partial fulfillment of the requirements \\ for the degree of \\ Doctoral of Musical Arts \\ in \\ Composition \\ John Beall, Ph.D.,Chair \\ Mary Ferer, Ph.D., Research Advisor \\ Andrew Kohn, Ph.D. \\ John Hendricks III, M.M. \\ Jay Malarcher, Ph.D.
}

Division of Music to School of Music

Morgantown, West Virginia

2013

Keywords: Vaughan Williams, Hodie

Copyright 2013 Ah Reum Han 


\title{
ABSTRACT
}

\section{Compositional Techniques in Hodie by Ralph Vaughan Williams}

\author{
Ah Reum Han
}

Hodie (This day) is Vaughan Williams's last large choral work. It is important because Vaughan Williams used not only complicated and innovative compositional techniques but also the largest instrumentation among his choral-orchestral compositions. It gives a challenging opportunity for composers who wish to learn innovative compositional techniques for vocal or choral-orchestral music. This research project will present Vaughan Williams's compositional techniques in a major choral-orchestral composition consisting of multiple movements. First, unification as a compositional method to link multiple movements by using recurring musical themes will be examined. Secondly, the treatment of biblical and non-biblical texts will be studied. Therefore, Hodie will be seen to represent a synthesis of compositional techniques based on the unique individuality of the musical style of Vaughan Williams. This project is divided into four chapters, 'Hodie: An Overview of the Work,' 'The Relationships of Biblical Narratives and Poetic Insertions,' 'Recurring Themes in Narrations and Other Movements,' and 'Hodie, Dona Nobis Pacem, and Sancta Civitas: A Comparison of Stylistic Change.' Various tables and musical examples in chapters are used to compare poetry and themes as well as musical ideas. 


\section{Table of Contents}

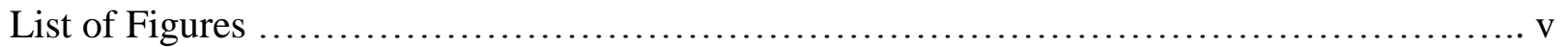

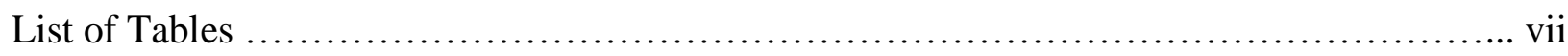

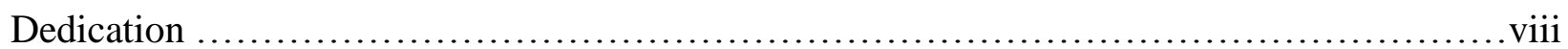

Chapter 1: Hodie: An Overview of the Work …........................................ 1

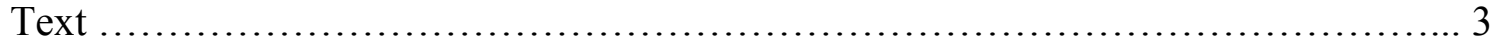

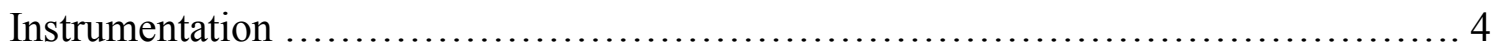

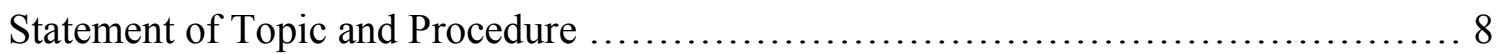

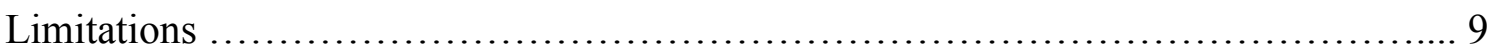

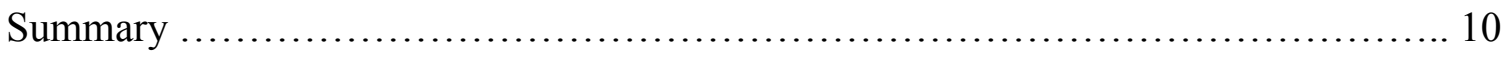

Chapter 2: The Relationships of Biblical Narratives and Poetic Insertions .................... 11

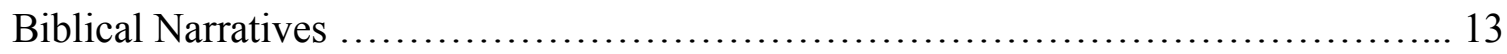

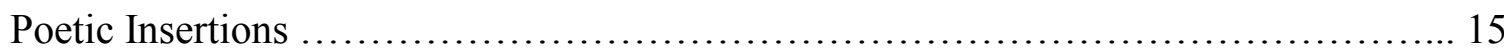

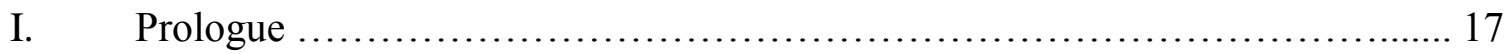

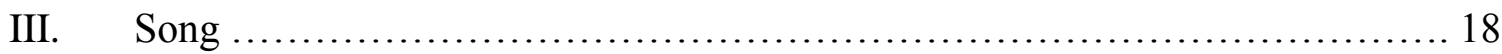

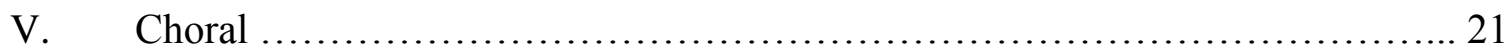

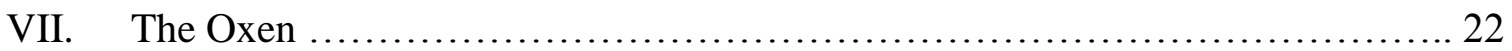

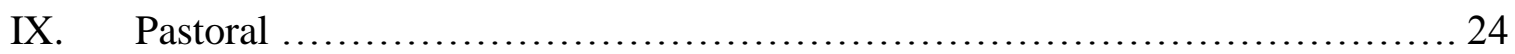

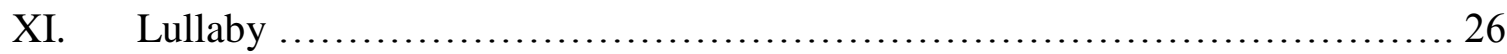

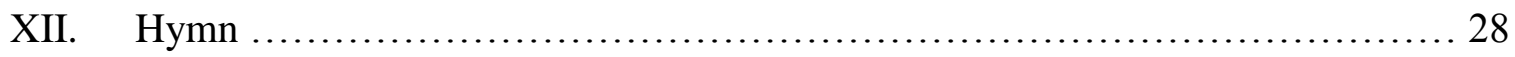

XIV. The March of the Three Kings …............................................... 30

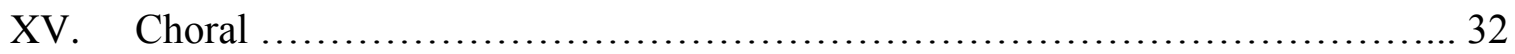

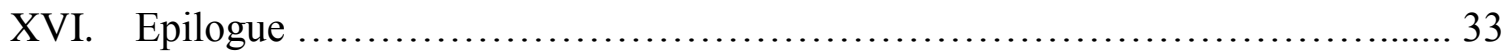

The Relationships of Biblical and Non-biblical Texts in Vaughan Williams' Other

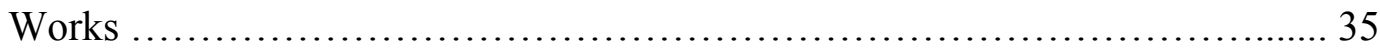

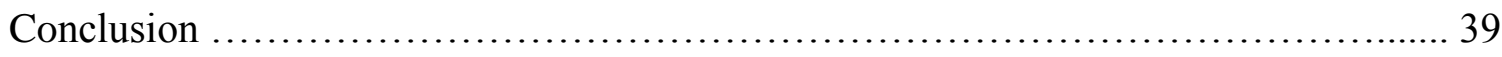

Chapter 3: Recurring Themes in Narrations and Other Movements .........................40

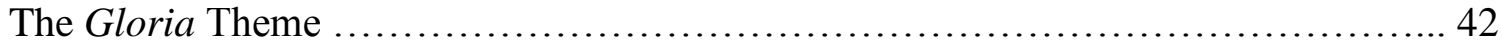

The Boy Evangelists Themes ................................................ 48

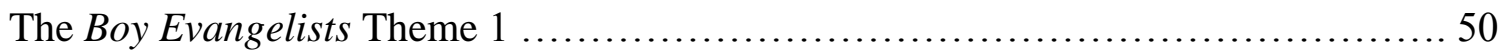

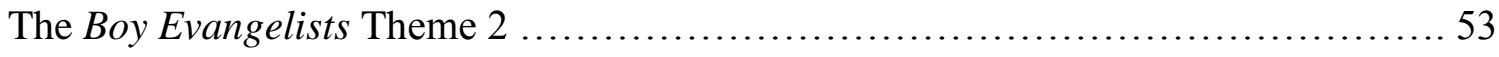

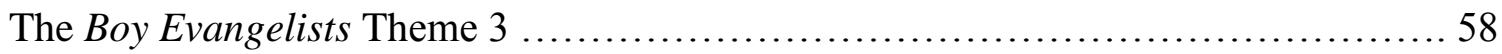

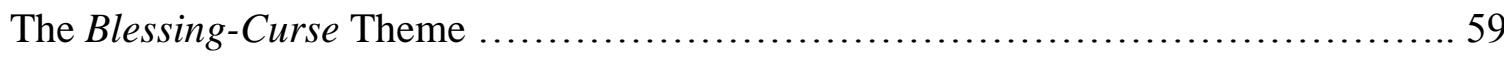

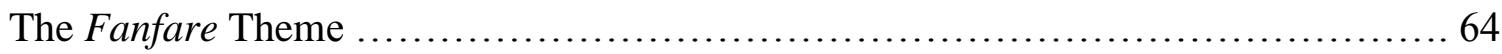

The 'Emmanuel, God with Us' Theme ............................................ 68 


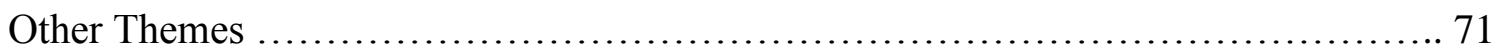

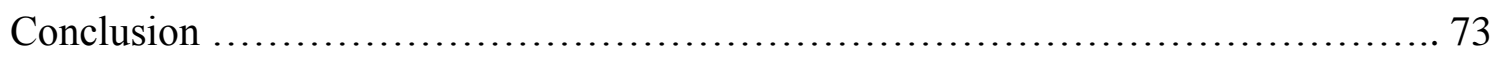

Chapter 4: Hodie, Dona Nobis Pacem, and Sancta Civitas: A Comparison of Stylistic

Change ................................................................ 75

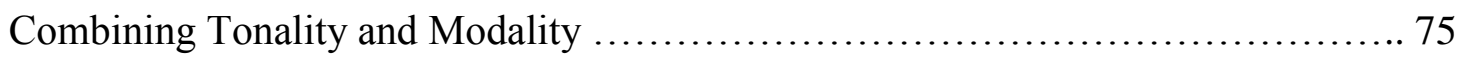

Recreating New Meaning from Biblical Text and English Poetry ................. 76

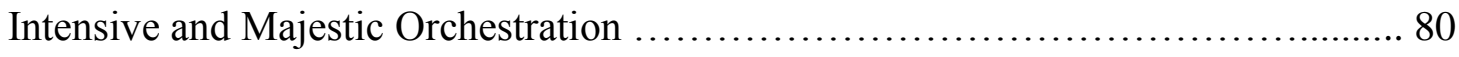

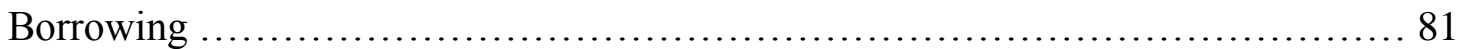

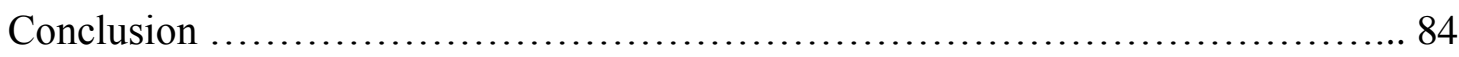

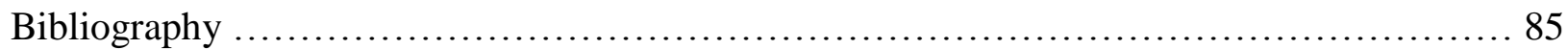




\section{List of Figures}

Figure 3-1: The G lydian scale and the Gloria theme in the soprano and alto entrance in the

'Prologue' (m. 65-8)..................................................... 43

Figure 3-2: The Glorias in the orchestra and mixed choir in the 'Prologue' (m. 56-74) ....... 44

Figure 3-3: The Gloria theme in Narration VI (m. 44- 55) ........................... 46

Figure 3-4: The Gloria theme in Narration VIII (m.10-30) ............................ 47

Figure 3-5: The boy evangelists theme 1 in Narration II (m. 1-5) ......................... 51

Figure 3-6: The boy evangelists theme 1 in Narration IV (m.1-21) ...................... 52

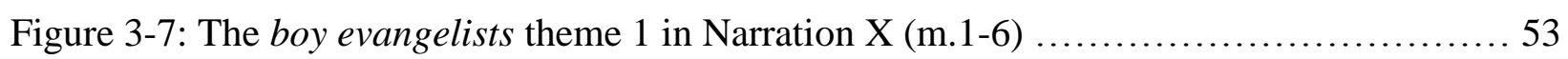

Figure 3-8: The boy evangelists theme 2 in Narration IV (m.17-26) ....................... 54

Figure 3-9: The boy evangelists theme 2 in Narration VI (m.1-9) ......................... 55

Figure 3-10: The boy evangelists theme 2 and the boy evangelists theme 3 in Narration XIII

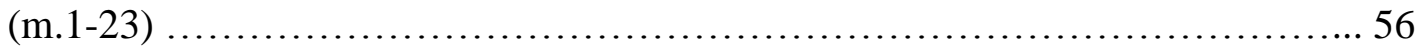

Figure 3-11: The boy evangelists theme 3 in Narration VI (m.129-138) .................... 58

Figure 3-12: The boy evangelists theme 3 in Narration VIII (m.1-9) ......................... 59

Figure 3-13: The blessing-curse theme and the extended blessing-curse theme ..............6 60

Figure 3-14: The blessing-curse theme in Narration II (m.27-38) ....................... 61

Figure 3-15: The blessing-curse theme in Narration VI (m.19-23) and (m.42-43) ............ 62

Figure 3-16: The blessing-curse theme in 'The March of The Three Kings' (m.28-32) and

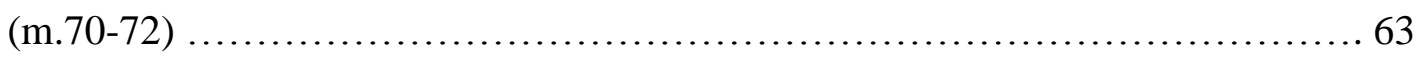

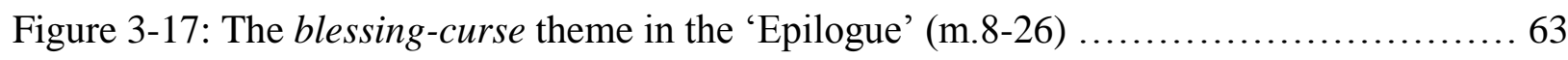

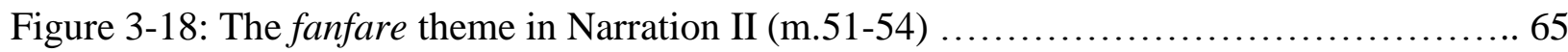

Figure 3-19: The fanfare theme in Narration II (m.66-69) ........................... 66

Figure 3-20: The fanfare theme in Narration VI (m.32-35) ........................... 66

Figure 3-21: The fanfare theme in 'The March of the Three Kings' (m.68-70) ...............67

Figure 3-22: The fanfare theme in 'The March of the Three Kings' (m.107-110) ........... 67

Figure 3-23: The fanfare theme in 'The March of the Three Kings' (m.161-164) .............67

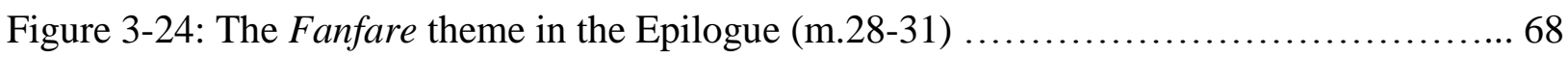


Figure 3-25: The 'Emmanuel, God with us' theme in Narration II (m.61-66) ................. 69

Figure 3-26: The 'Emmanuel, God with us' theme in the 'Epilogue' (m.31-37) .............. 70

Figure 3-27: The alternating $F$ sharp minor and F minor chords theme in Narration II

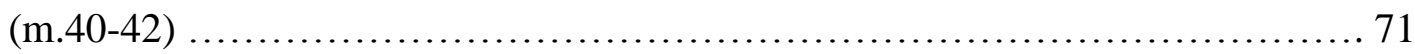

Figure 3-28: The alternating F sharp minor and F minor chords theme in the 'Epilogue'

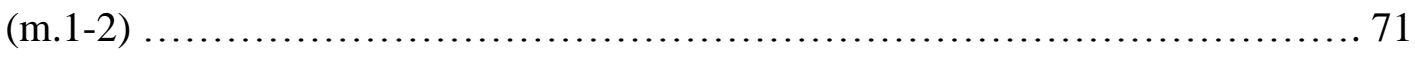

Figure 3-29: The rising bass line theme in Narration II (m.43-49) ........................ 72

Figure 3-30: The rising bass line theme in the 'Epilogue' (m.3-9) ......................... 72 


\section{Lists of Tables}

Table 1.1: The List of Instrumentation and Texts of the Movements...................... 5

Table 2.1: Biblical Texts and Their Sources ....................................... 14

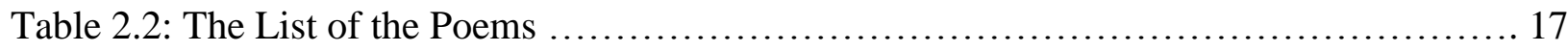

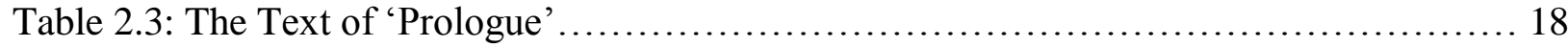

Table 2.4: The Text of the 'Song' ................................................ 20

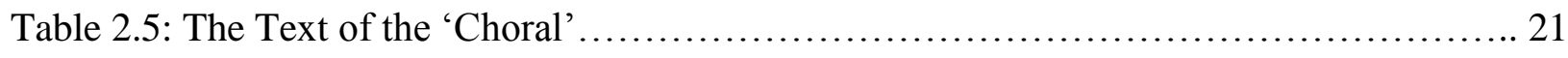

Table 2.6: The Text of the 'The Oxen' ............................................ 24

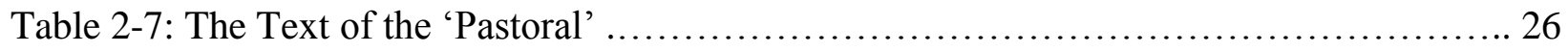

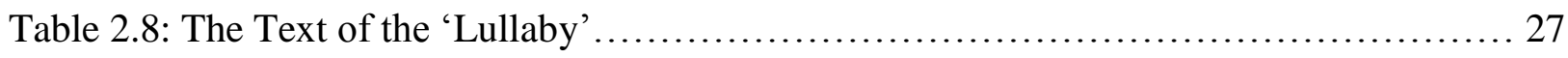

Table 2.9: The Text of the 'Hymn' ................................................. 29

Table 2.10: The Text of the 'The March of The Three Kings' ............................ 31

Table 2.11: The Text of the 'Choral' .............................................. 33

Table 2.12: The Comparison of The Third and Sixteenth Movements of Hodie ............... 33

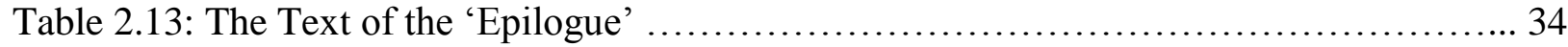

Table 3.1: Recurring Themes in Hodie ........................................... 41

Table 3.2: The Gloria theme ................................................... 43

Table 3.3: The Boy Evangelists Theme 1 ........................................ 49

Table 3.4: The Boy Evangelists Theme 2 ....................................... 49

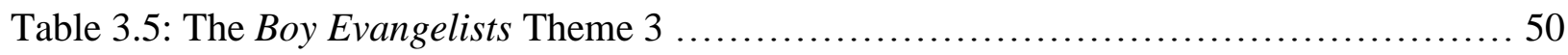

Table 3.6: The Blessing-Curse Theme ......................................... 60

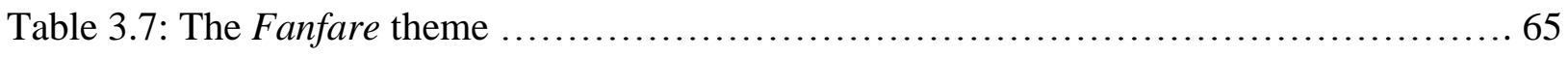

Table 3.8: The 'Emmanuel, God with us' theme ...................................... 68

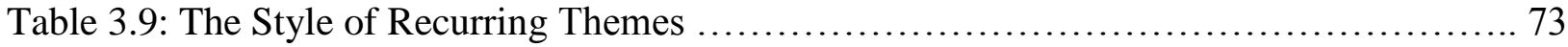

Table 4.1: Borrowing in Hodie ............................................... 82

Table 4.2: Borrowing in Sancta Civitas ............................................... 83

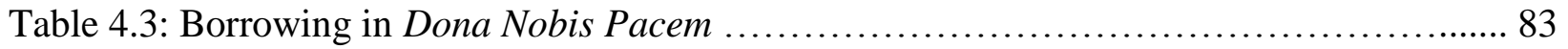




\section{Dedication}

This Research Project is dedicated to my research advisor Mary Ferer, my professor John Beall, and my parents Duck Gye Han and Kyoung Lae Sin. It could not be completed without their love, support, and encouragement. 


\section{Chapter 1. Hodie: An Overview of the Work.}

It was almost inevitable that at some time Ralph Vaughan Williams would write a major work celebrating Christmas: the festival's magical fusion of the earthly and the mystical, of veneration of tradition with the promise of new life, was fundamental to Vaughan Williams's entire artistic outlook. ${ }^{1}$

Ralph Vaughan Williams, English composer, teacher, writer, arranger, and conductor, was born at Down Ampney on 12 October 1872, and died at London on 26 August 1958. He composed various works, including nine symphonies, four concertos, twenty orchestral works, five operas, eight chamber works, and dozens of works for chorus and orchestra, as well as smaller-scale vocal and choral music. Studies of Vaughan Williams have often remarked on the Englishness of his style, an "English national identity in music.", The composer himself emphasized that "the English composer should focus on his own country and its culture, rather than attempt an imitation of the 'great' composers."3 Englishness was made by re-creating an English musical vernacular in his works, and finally it became one of his significant musical characteristics. In musical style, he preferred contemplative lyrical expressions rather than dynamic or active statements. This inclination reflected "his humanistic belief in direct musical expression accessible to a wide audience." 4 Vaughan Williams's musical language was founded

\footnotetext{
${ }^{1}$ Alain Frogley. Vaughan Williams: Hodie (A Christmas Cantata). CD Booklet. Musical Heritage: London. 1990: 3 .

${ }^{2}$ Alain Frogley. "Constructing Englishness in Music: National Character and the Reception of Ralph Vaughan Williams.” Vaughan Williams Studies: 1-22. New York: Cambridge University Press, 1996: 4.

${ }^{3}$ Ralph Vaughan Williams and David Manning. Vaughan Williams On Music. edited by David Manning. Oxford: Oxford University Press, 2008: 4.

${ }^{4}$ Hugh Ottaway and Alain Frogley. "Vaughan Williams, Ralph." Grove Music Online. Oxford Music Online. Oxford University Press. http://www.oxfordmusiconline.com/subscriber/article/grove/music/42507 [accessed May 26, 2013].
} 
on tonality, modality, and pentatonicisim with melody-based form. He not only reinvented but also rejected the illustrious accomplishments of the nineteenth-century composers including Richard Wagner and Liszt, and also added Debussyan musical characters including added-note chords and chromaticism. ${ }^{5}$

Hodie, ${ }^{6}$ a cantata for Christmas, was written between 1953-4 in his final years, and was Vaughan Williams's last major choral-orchestral composition. It was dedicated to Herbert Howells (1892-1983), ${ }^{7}$ one of Vaughan Williams's fellow composers who had been inspired by Vaughan Williams's many works. ${ }^{8}$ Hodie presents all of Vaughan Williams's musical styles and innovative compositional techniques which ranged "during his long career, from folky lyricism, to polytriadic mystery, to Holstian motor rhythm." "9 This work also presents Vaughan Williams's late harmonic language, described as a traditional diatonic idiom moving from one tonal center

${ }^{5}$ Hugh Ottaway and Alain Frogley.

6 "The Latin phase, Hodie, Christus Natus Est ("Today Christ In Born”) has long introduced Christmas vespers, and settings of that text have been made by dozens of composers. The original title of Vaughan Williams' work, "This Day," gave way to Hodie by his preference, but it bears only slight resemblance to those liturgical works." J. R. Fancher. "Hodie (This Day) by Ralph Vaughan Williams." The Naperville Chorus. http://www.napervillechorus.org/program_notes/pn_200404_HodieRVW.html [accessed June 5, 2013].

7 "In one of the front pages of the score is written: 'Dear Herbert, I find that in this cantata I have inadvertently cribbed a phrase from your beautiful 'Hymnus Paradisi.' Your passage seems so germane to my context that I have decided to keep it. R.V.W."...Howells wrote back to Vaughan Williams: 'My dear Ralph, I have the score of This Day safely. Nothing has ever touched me more than its dedication- Bless you...' Ironically, when anyone asked both men about the dedication, neither composer could remember what phrase was referred to in either work." Paul James Etter. "Ralph Vaughan Williams' "Hodie": An Analysis and Performance Guide for the Choral Conductor." Ph.D., Texas Tech University, 2002. In ProQuest Dissertations and Theses, http://search.proquest.com/pqdtft/docview/305482745/13E44A9D9F9519F22FB/2?accountid=2837 [accessed May 26, 2013]: 40 .

8 "Herbert Howells said that the one experience which stood out as a vitally determining factor in his life was his first encounter with Vaughan Williams's Fantasia on a Theme by Thomas Tallis. It was after then that I felt I really knew myself, both as a man and artist. It all seemed so incredibly new at the time, but I soon came to realize how very, very old it actually was, how I'd been living the music since long before I could ever begin to remember." Lionel Pike. "Tallis: Vaughan Williams: Howells: Reflections on Mode Three." Tempo, no. 149 (June 1984): 2.

${ }^{9}$ Wilfrid Mellers. "Vaughan Williams, Hodie.” The Musical Times 107, no. 1477 (March 1966): 226. 
to another smoothly. ${ }^{10}$ Hodie reflects as well the stylistic diversity of "the various strands of the Christmas experience and the contrasting worlds within the anthology of poems that forms the heart of the work."11 The orchestration of Hodie is "outstandingly clear and imaginative,"12 and the full orchestral ensemble is the largest to be found in Vaughan Williams's choral-orchestral works. $^{13}$

\section{Text}

The texts of the cantata are taken from the biblical account of the birth of Jesus as well as from poems by various poets from the sixteenth to the twentieth centuries including the wife of the composer. In his 2002 dissertation, Paul James Etter described the process of choosing texts for Hodie.

In 1953-4, Vaughan Williams determined to compose a work using narration and chorus to recount the Christmas story. He expressed this aspiration to his wife, Ursula, but was still looking for the right text. In her biography of Vaughan Williams, Ursula recalls the incident: 'I said that I had compiled a program of Christmas poems, using linking passages from the gospels, and I had put it away and forgotten about it. When I took it to Dorking, Ralph got out his own scenario and the two were almost identical...' Looking for a suitable poem for the three kings was challenging... Vaughan Williams then asked Ursula to write a poem for the Kings, as well as to extend the anonymous poem... ${ }^{14}$

\footnotetext{
${ }^{10}$ James L. Queen. "Ralph Vaughan Williams: Hodie and Fantasia on Christmas Carols.” Choral Journal (September 2008): 102 .

${ }^{11}$ Frogley, 3.

${ }^{12}$ Allen L. Borton. "Ralph Vaughan Williams's Hodie at Forty." Choral Journal 35, no. 5 (December 1994$): 17$.

${ }^{13}$ Frogley, 3.

${ }^{14}$ Etter, 34.
} 
Narrations containing biblical quotations as found in the Gospels of Matthew, Luke, and John alternate with poetic insertions. The poems, entitled "Prologue," "Song," "Choral," "The Oxen," "Pastoral," Lullaby," "Hymn," "The March of The Three Kings," and "Epilogue," are drawn from English literature from sixteenth to the twentieth centuries written by John Milton, George Herbert, William Drumond, Miles Coverdale, Thomas Hardy, and Ursula Vaughan Williams. They present "reflection upon and emotional response to the events of the Nativity as recounted in the narrative portions of the cantata." ${ }^{" 15}$ This compositional technique, the alternation of narrative account and poetic insertion, recalls the scriptural passages enhanced by poetic commentary in the Bach's Passions, but here recreated by Vaughan Williams in his own style.

England's past, as well as the individual psyche, is here renascent, the convention being that of a pristine English oratorio, merged into an Anglicized version of the Bachian Passion or sacred history - a convention which, by then, was a part of English life. Simply harmonized carols take the place of Lutheran chorales, representing us the people; unisonal treble soloists become boy evangelists, narrating the story in recitative suggested by the liturgy of the English Reformed, instead of the German Lutheran, Church. $^{16}$

\section{Instrumentation}

Hodie consists of six Narrations and ten poetic insertions from English literature as well as words from Vespers for Christmas Day. All the Narrations are scored for boy's choir in unison, accompanied with either organ or full orchestra. Sometimes the boy's choir is joined by soloists and mixed choir or women's choir. The Narrations tell "the tale of Christ's miraculous

\footnotetext{
${ }^{15}$ Frogley, 3.

${ }^{16}$ Mellers, 210.
} 
birth and the visitation of the angelic messenger,"17 and are used as "a device which ensures impersonality and neutrality." ${ }^{\prime 18}$ The poetic insertions are comprised of ten movements for a cappella mixed choir, for soloist, for soloist and choir added intermittently to enrich the solo, as well as music for choir and several soloists. Most movements present various instrumentation reflecting the imagery and mood of the texts. The instrumentation and sources for the texts are as follows:

Table. 1.1 The List of Instrumentation and Texts of the Movements

\begin{tabular}{|c|c|c|c|}
\hline \multicolumn{2}{|c|}{ Movement } & \multirow[b]{2}{*}{$\begin{array}{l}\text { Instrumentation } \\
\text { Mixed Choir and Orchestra: } \\
3 \text { Flutes (3th flute doubling Piccolo), } 2 \text { Oboes, } \\
\text { English horn, 2 Bb Clarinets, 2 Bassoons, 1 } \\
\text { Contra Bassoon, 4 F Horns, } 3 \text { Bb Trumpets, } 3 \\
\text { Trombones, 1 Tuba, Timpani, Percussion, Celesta, } \\
\text { Harp, Piano, Organ, and Strings. }\end{array}$} & Text \\
\hline I. & Prologue & & $\begin{array}{l}\text { From the Vespers } \\
\text { for Christmas Day }\end{array}$ \\
\hline II. & Narration & $\begin{array}{l}\text { Boys Choir, Tenor Solo, Mixed Choir, and } \\
\text { Orchestra: } \\
3 \text { Flutes (3th flute doubling Piccolo), } 2 \text { Oboes, } \\
\text { English horn, } 2 \text { Bb Clarinets, } 2 \text { Bassoons, } 1 \\
\text { Contra Bassoon, } 4 \text { F Horns, } 3 \text { Bb Trumpets, } 3 \\
\text { Trombones, } 1 \text { Tuba, Timpani, Percussion, Harp, } \\
\text { Piano, Organ, and Strings. }\end{array}$ & $\begin{array}{l}\text { From Matthew 1:18-21 } \\
\text { and 23, and Luke 1: } 32\end{array}$ \\
\hline III. & Song & $\begin{array}{l}\text { Soprano Solo, Mixed Choir, and Orchestra: } \\
3 \text { Flutes (3th flute doubling Piccolo), } 2 \text { Oboes, } \\
\text { English horn, } 2 \text { Bb Clarinets, } 2 \text { Bassoons, } 1 \\
\text { Contra Bassoon, } 4 \text { F Horns, } 3 \text { Bb Trumpets, } 3 \\
\text { Trombones, } 1 \text { Tuba, Timpani, Percussion, Celesta, } \\
\text { Harp, Piano, and Organ. }\end{array}$ & $\begin{array}{l}\text { From "Hymn on the } \\
\text { Morning of Christ's } \\
\text { Nativity" } \\
\text { by John Milton }\end{array}$ \\
\hline IV. & Narration & Boys Choir and Organ & From Luke 2:1-7 \\
\hline V. & Choral & A Cappella for Mixed Choir & $\begin{array}{l}\text { A translation by Miles } \\
\text { Coverdale of a Hymn } \\
\text { by Martin Luther }\end{array}$ \\
\hline
\end{tabular}

\footnotetext{
${ }^{17}$ Mellers, 211.

${ }^{18}$ Mellers, 211.
} 


\begin{tabular}{|c|c|c|c|}
\hline VI. & Narration & $\begin{array}{l}\text { Boys Choir, Soprano solo, Tenor solo, Mixed } \\
\text { Choir, and Orchestra: } \\
3 \text { Flutes (3th flute doubling Piccolo), } 2 \text { Oboes, } \\
\text { English horn, } 2 \text { Bb Clarinets, } 2 \text { Bassoons, } 1 \\
\text { Contra Bassoon, } 4 \text { F Horns, } 3 \text { Bb Trumpets, } 3 \\
\text { Trombones, } 1 \text { Tuba, Timpani, Percussion, Celesta, } \\
\text { Harp, Piano, Organ, and Strings. }\end{array}$ & $\begin{array}{l}\text { Adapted by composer } \\
\text { from Luke } 2: 8-17 \text {, } \\
\text { and the Book of Common } \\
\text { Prayer }\end{array}$ \\
\hline VII. & The Oxen & $\begin{array}{l}\text { Baritone Solo and Orchestra: } \\
3 \text { Flutes, } 1 \text { Oboe, English horn, } 2 \text { A Clarinets, } 2 \\
\text { Bassoons, } 2 \text { F Horns, and Strings. }\end{array}$ & $\begin{array}{l}\text { From "The Oxen" } \\
\text { by Thomas Hardy }\end{array}$ \\
\hline VIII. & Narration & $\begin{array}{l}\text { Boys Choir, Women Choir, and Orchestra: } \\
3 \text { Flutes (3th flute doubling Piccolo), } 2 \text { Oboes, } \\
\text { English horn, } 2 \text { A Clarinets, } 2 \text { Bassoons, } 4 \text { F } \\
\text { Horns, } 3 \text { Bb Trumpets, } 1 \text { Trombone, Timpani, } \\
\text { Celesta, Harp, Organ, and Strings. }\end{array}$ & From Luke 2:20 \\
\hline IX. & Pastoral & $\begin{array}{l}\text { Baritone Solo and Orchestra: } \\
2 \text { Flutes, } 1 \text { Oboe, } 2 \text { A Clarinets, } 2 \text { Bassoons, } 2 \text { F } \\
\text { Horns, } 2 \text { Bb Trumpets, and Strings. }\end{array}$ & $\begin{array}{l}\text { From a poem } \\
\text { by George Herbert }\end{array}$ \\
\hline $\mathbf{X}$. & Narration & Boys Choir and Organ & From Luke 2:19 \\
\hline XI. & Lullaby & $\begin{array}{l}\text { Soprano Solo, Women Choir, and Orchestra: } \\
2 \text { Flutes, } 2 \text { Bb Clarinets, } 2 \text { Bassoons, } 2 \text { F Horns, } \\
\text { Harp, Piano, Strings, and Soprano Solo, and } \\
\text { Women Choir. }\end{array}$ & From William Ballet \\
\hline XII. & Hymn & $\begin{array}{l}\text { Tenor Solo and Orchestra: } \\
2 \text { Flutes, } 2 \text { Oboes, English horn, } 2 \text { Bb Clarinets, } 2 \\
\text { Bassoons, } 2 \text { F Horns, } 2 \text { Bb Trumpets, } 3 \\
\text { Trombones, Timpani, Percussion, Celesta, Harp, } \\
\text { Piano, and Strings. }\end{array}$ & $\begin{array}{l}\text { From "Christmas Day" } \\
\text { by William Drummond }\end{array}$ \\
\hline XIII. & Narration & $\begin{array}{l}\text { Boy's Choir, Mixed Choir and Orchestra: } \\
2 \text { Flutes, } 1 \mathrm{Bb} \text { Clarinet, } 4 \text { F Horns, Organ, and } \\
\text { Strings. }\end{array}$ & $\begin{array}{l}\text { Adapted from Matthew } \\
2: 1-2 \text {, and } 11\end{array}$ \\
\hline XIV. & $\begin{array}{l}\text { The March } \\
\text { Of The Three } \\
\text { Kings }\end{array}$ & $\begin{array}{l}\text { Soprano Solo, Tenor Solo, Baritone Solo, } \\
\text { Mixed Choir, and Orchestra: } \\
3 \text { Flutes (3th flute doubling Piccolo), } 2 \text { Oboes, } \\
\text { English horn, } 2 \text { Bb Clarinets, } 2 \text { Bassoons, } 1 \\
\text { Contra Bassoon, } 4 \text { F Horns, } 3 \text { Bb Trumpets, } 3 \\
\text { Trombones, } 1 \text { Tuba, Timpani, Percussion, Harp, } \\
\text { Piano, and Strings. }\end{array}$ & $\begin{array}{l}\text { From a poem } \\
\text { by Ursula Vaughan } \\
\text { Williams }\end{array}$ \\
\hline $\mathbf{X V}$. & Choral & A Cappella for Mixed Choir & $\begin{array}{l}\text { From an anonymous } \\
\text { poem for the first verse } \\
\text { and from a poem by } \\
\text { Ursula Vaughan Williams } \\
\text { for the second verse. }\end{array}$ \\
\hline XVI. & Epilogue & $\begin{array}{l}\text { Soprano Solo, Tenor Solo, Baritone Solo, } \\
\text { Mixed Choir, and Orchestra: } \\
1 \text { Piccolo, } 2 \text { Flutes, } 2 \text { Oboes, English horn, } 2 \text { Bb } \\
\text { Clarinets, } 2 \text { Bassoons, } 1 \text { Contra Bassoon, } 4 \text { F } \\
\text { Horns, } 3 \text { Bb Trumpets, } 3 \text { Trombones, } 1 \text { Tuba, } \\
\text { Timpani, Percussion, Harp, Piano, Organ, and Strings. }\end{array}$ & $\begin{array}{l}\text { Adapted from John 1:1-14 } \\
\text { and from "Hymn on the } \\
\text { Morning of Christ's } \\
\text { Nativity" by John Milton. }\end{array}$ \\
\hline
\end{tabular}


According to Allen L. Borton, "In Hodie, Vaughan Williams draws heavily on the work of Renaissance poets. In discussing the tone of that poetry, one commentator notes, 'Hodie has exactly that somewhat naïve vitality and delight in praising God that appears to have been such a feature of early Renaissance Italy.' Examples can be found at the beginning of the Coverdale chorale, 'The Blessed Son of God,' or the beginning of 'Bright Portals of the Sky' setting a Drummond text." ${ }^{, 19}$ Alain Frogley explains that "Hodie also underscores Vaughan Williams's lifelong involvement with English literary as well as musical tradition, particularly the glories of seventeenth-century poetry and prose, here represented by Milton, Herbert, Drummond, and the King James Bible (the last a perennial source of inspiration to the composer). ${ }^{, 20}$ Therefore, the poetic commentaries not only enrich the content of the Narrations, but also support them. The technique of combining texts from sacred and secular sources is found in his other cantata, Dona Nobis Pacem (1936). The texts of this work were taken from the Mass, the Bible, a political speech by John Bright, and three poems by Walt Whitman. ${ }^{21}$ Unlike Hodie, Vaughan Williams blended various texts into a single movement in the Dona Nobis Pacem.

The premiere of this work was given at the Three Choirs Festival at Worcester on 8 September 1954, performed by Nancy Evans (mezzo-soprano), Eric Greene (tenor), Gordon Clinton (baritone), the Festival Chorus, and the London Symphony Orchestra, conducted by the composer. Hodie was published by Oxford University Press in 1954, and its duration is approximately fifty minutes. The work is scored for mixed chorus; soloists consisting of tenor,

\footnotetext{
${ }^{19}$ Borton, 17.

${ }^{20}$ Frogley, 4.

${ }^{21}$ Borton, 17.
} 
baritone, and soprano; boys' choir; organ; and orchestra. The full instrumentation is as follows: 3 flutes (doubling piccolo), 3 oboes (doubling cor anglais), 2 Bb clarinets, 2 bassoons, double bassoon, $4 \mathrm{~F}$ horns, $3 \mathrm{Bb}$ trumpets, 2 tenor trombones, bass trombone, tuba, timpani, percussion, celesta, harp, pianoforte, organ, and strings. The first performance of Hodie was followed by a number of critical reviews. Etter has described several in his recent dissertation.

The columnists of The Times and the Daily Telegraph received this first London appearance, conducted by Sir Malcolm Sargent, considerately. The general public may have admired these performances, but other critics did not. Not only did they give unfavorable reviews to Hodie, but their reaction to the cantata also began a critical reaction against Vaughan Williams and his previous works as well as his pre-eminent status in English music. The following April and May issue of Musical Opinion published a harsh analysis of the work by Donald Mitchell...in the review, he also states: 'If this is the kind of music that rouses cries of exaltation, then our musical culture is in worse condition than I thought possible... There is a level below which 'directness' and 'forthrightness' of utterance - qualities for which Vaughan Williams is praised - deteriorate into a downright unacceptable and damaging primitivity...It is doubly damaging when his contemporaries are so blind (or deaf, perhaps) that they mistake patent coarseness as evidence of exuberant genius. $^{22}$

Despite Mitchell's misgivings, Hodie has won for itself a place of honor that refutes such early criticisms.

\section{Statement of Topic and Procedure}

Hodie (This day) is important because Vaughan Williams used not only complicated and innovative compositional techniques but also the largest instrumentation among his choralorchestral compositions. It gives a challenging opportunity for composers who wish to learn innovative compositional techniques for vocal or choral-orchestral music. This research project

\footnotetext{
${ }^{22}$ Etter, 42.
} 
will present Vaughan Williams's compositional techniques in a major choral-orchestral composition consisting of multiple movements. First, unification as a compositional method to link multiple movements by using recurring musical themes will be examined. Secondly, the treatment of biblical and non-biblical texts will be studied. Therefore, Hodie will be seen to represent a synthesis of compositional techniques based on the unique individuality of the musical style of Vaughan Williams.

The purpose of this study will be:

1. to present a brief biographical account of Vaughan Williams's life, his religious ideas, musical philosophies, and compositional style.

2. to examine the texts, first performance, and instrumentation of Hodie.

3. to consider the relationships between the biblical narratives and various poetic insertions in the cantata.

4. to explain recurring themes in the Narrations and Poetic Insertions.

5. to compare Hodie with Vaughan Williams's Dona Nobis Pacem and Sancta Civitas

To achieve the stated goals, the study will be divided into the following chapters:

I. Hodie: An Overview of the work.

II. The Relationships between Biblical Narratives and Poetic Insertions

III. Recurring Themes in the Narrations and Other Movements

IV. Hodie, Dona Nobis Pacem, and Sancta Civitas: A Comparison of Stylistic Change

\section{Limitations}

This project will not include a theoretical analysis of harmonic progression. Instead, it will focus on recurring themes as unifying elements in the cantata as well as on the relationships between biblical and non-biblical texts. Labeling of modes will conform to earlier publications that discuss Hodie. 


\section{Summary}

Hodie is Vaughan Williams's last major choral-orchestral composition written in his final years. It is based on the biblical account of the birth of Jesus, and presents Vaughan Williams's late harmonic language, stylistic diversity, as well as brilliant orchestration. Hodie recreated the sequence of biblical narration and poetic commentary as it existed in Bach's Passions but in a style that is Vaughan Williams's own. The ideas of the various poems inserted between Narrations provide supplementary explanations and descriptions relating to the biblical account and present different instrumentation inspired by the imagery and mood of the texts. 


\section{Chapter 2. The Relationships of Biblical Narratives and Poetic Insertions}

The practice of combining texts from sacred and secular sources is a convention used frequently by English composers, ... its catholicity is one of the work's greatest strengths and most delightful characteristics. ${ }^{1}$

According to Byron Adams, "Vaughan Williams's use of biblical texts is of particular interest, illuminating the development of his personal beliefs and his desire to create an aesthetic that would embrace his visionary impulse, as well as casting new light on the cultural nationalism which led him to honour the liturgy and musical traditions of that unique institution, the Church of England." "Vaughan Williams's non-biblical texts in his vocal and choral music were taken from three types. The first type was words based on the combination of folk and lyrics styles derived from authentic folk songs. Another type was texts selected from rondels and sonnets in poetic forms. The last type was poems which reflected a mystical nature of seventeenth-century English literature ${ }^{3}$ Hodie belongs to the last type. Thus, English nationalism is reflected by the choice of English poems with elements of English folklore. ${ }^{4}$

Vaughan Williams composed approximately twenty-six choral works during his lifetime.

Two typical characteristics found in these works are the use of combining biblical and nonbiblical texts and the use of through-composed form, a form determined by the texts. Like many

\footnotetext{
${ }^{1}$ Allen L. Borton. "Ralph Vaughan Williams's Hodie at Forty." Choral Journal 35, no. 5 (December 1994): 17.

${ }^{2}$ Byron Adams. "Scripture, Church, and Culture: Biblical Texts in the Works of Ralph Vaughan Williams." Vaughan Williams Studies. New York: Cambridge University Press, 1996: 100.

${ }^{3}$ William Kimmel. "Vaughan Williams's Choice of Words." Music \& Letters 19, no. 2 (April 1938): 132.

4 "He deeply loved the Authorized Version of the Bible and he recognized its central position in the development of English language, culture, and society, expropriating like most other English artists an anthology of Middle Eastern historical and poetic texts, considering their translations as uniquely English as 'Bushes and Briars." Adams, 108.
} 
previous composers, Vaughan Williams combined secular and sacred texts in most of his choral works. ${ }^{5}$ However, texts were reconstructed in his own unique style. Adams explains that "Vaughan Williams does not scruple in stripping a biblical passage of its context and modifying its meaning by juxtaposition with other texts, sometimes biblical, but often taken from sources quite foreign to the Bible, such as Thomas Hardy or Walt Whitman."6 "By removing biblical passages from their original surroundings and juxtaposing them with other texts, he manipulated their context and subtly modified their import - powerful metaphors are thus used to generate new meanings."7 Therefore, the combining of religious and non-religious texts, as a compositional strategy, not only provided richer or new meanings for the work, but also reflected the composer's precise purpose concerning the work and English nationalism. This strategy was followed in Hodie.

The through-composed form in most of Vaughan Williams's choral works allowed him to exceedingly emphasize the meaning and mood of the words. In this sense, the texts determined the form. Ursula Vaughan Williams reminisced that "Whenever Ralph was rehearsing a choral work he would read the words to the choir, before they attempted the music, to make his singers understand the mood and the quality of the poem."8 Wilfrid Mellers, an English music critic, musicologist, and composer, believed that the compositional procedures of Vaughan Williams's

\footnotetext{
5 “Given his freedom from religious belief or vision of a conventional or institutional kind, and his commitment to the notion of art as social expression, he felt no constraints in selecting and adapting these texts for his own devices, just as he freely selected, arranged, and developed folksongs throughout his career, transforming them in the process and making them utterly his own." Adams, 108.

${ }^{6}$ Adams, 100, "In contrast, Vaughan Williams is scrupulously careful when setting poetry to reflect its prosody in his music."

${ }^{7}$ Adams, 110.

8 Ursula Vaughan Williams. "Ralph Vaughan Williams and His Choice of Words for Music.” Proceedings of the Royal Musical Association 99 (1972): 88.
} 
choral music were based on sectional rather than developmental procedures. ${ }^{9}$ In other words, the forms in his choral music depended on the texts, and the significant regard Vaughan Williams had for the texts determined his compositional methods.

This chapter will discuss the contents and sources of the biblical narratives and nonbiblical texts (poetic insertions) of Hodie. Also, other examples of large-scale choral works that combine biblical and non-biblical texts will be presented at the end of the chapter.

\section{Biblical Narratives}

Hodie consists of sixteen movements, which recount and reflect on the birth of Christ, ${ }^{10}$ with texts taken from the biblical account of the birth of Jesus, as found in the Gospels of Matthew, Luke, and John. ${ }^{11}$ They are presented in "pentatonic recitative with scarcely a hint of 'expressive' word-painting." 12 The Narrations were usually sung by a boy's choir (sometimes soloist or soloists added). The boy's choir ${ }^{13}$ not only symbolized "the visitation of the angelic messenger," but was "a device which ensures impersonality and neutrality." 14 Adams explains that "expressed in large part through a love of the Anglican musical tradition, and of the language of the Book of Common Prayer and the Authorized Version [of the Bible], Vaughan

${ }^{9}$ Wilfrid Mellers. Vaughan Williams and the Vision of Albion. Illminster: Albion Music, 1997: 210.

${ }^{10}$ Byron Adams stated that "a particular moving and telling example of textual juxtaposition is found in a late work, the large-scale Christmas cantata for three soloists, chorus, and orchestra entitled Hodie,...” Adams, 100.

11 "The words themselves, as well as their setting, suggest that this is an old tale that happened in the onceupon-a-time, yet is vital to us all: as is appropriate to Vaughan Williams's view of the matter, which takes the tale as psychologically true but in the strict sense mythical rather than historical." Mellers, 211.

${ }^{12}$ Mellers, 226.

13 "The music for the boy evangelists is close to that of the Woodcutter's Boy in the Delectable Mountains scene of The Pilgrim's Progress; and we have noted the sense in which he was a rebirth." Mellers, 210.

${ }^{14}$ Mellers, 211. 
Williams's cultural nationalism let him to select texts whose metaphors spoke directly to the English community through a common religious heritage." ${ }^{15}$ Mellers believed that "it is significant that Vaughan Williams should treat the story archetypically ..., setting it in a traditionally Christian social context..., narrating the story in recitative suggested by the liturgy of the English Reformed, instead of the German Lutheran, Church." ${ }^{16}$ That is to say, the concept of the birth of Christ had been used by many composers of the previous generations as an important subject matter for their music. However, Vaughan Williams in his own way reflected English nationalism in the selection of texts and music for Hodie. ${ }^{17}$ Table 2.1 presents the texts and their biblical sources.

Table 2.1 Biblical Texts and Their Sources

\begin{tabular}{|c|c|c|}
\hline Movement & Text & Source \\
\hline II. & $\begin{array}{l}\text { Now the birth of Jesus Christ was on this wise: whenas his mother Mary } \\
\text { was espoused to Joseph, before they came together, she was found with } \\
\text { child of the Holy Ghost.Then Joseph her husband, being a just man, was } \\
\text { minded to put her away privily. But while he thought on these things, } \\
\text { behold, the angel of the Lord appeared unto him in a dream. } \\
\text { Angel } \\
\text { "Joseph, thou son of David, fear not to take unto thee Mary thy wife: for } \\
\text { that which is conceived in her is of the Holy Ghost. And she shall bring } \\
\text { forth a son, and thou shalt call his name Jesus: He shall be great, and shall } \\
\text { be called the son of the Highest: Emmanuel, God with us." }\end{array}$ & $\begin{array}{l}\text { From Matthew } \\
1: 18-21,23 \text {, and } \\
\text { Luke } 1: 32\end{array}$ \\
\hline IV. & $\begin{array}{l}\text { And it came to pass in those days, that there went out a decree from Caesar } \\
\text { Augustus, that all the world should be taxed. And all went to be taxed, } \\
\text { everyone into his own city. And Joseph also went up unto the city of } \\
\text { David, which is called Bethlehem; to be taxed with Mary his espoused } \\
\text { wife, being great with child. And so it was that while they were there, the } \\
\text { days were accomplished that she should be delivered. And she brought } \\
\text { forth he first born son, and wrapped him in swaddling clothes, and laid him } \\
\text { in a manager; because there was no room for them in the inn. }\end{array}$ & $\begin{array}{l}\text { From Luke } \\
2: 1-7\end{array}$ \\
\hline
\end{tabular}

${ }^{15}$ Adams, 110.

${ }^{16}$ Mellers, 209-10.

17 "Tudor church music, and especially the verse anthems of Byrd and Gibbons, had as great an influence as folksong on the development of Vaughan Williams's style... Vaughan Williams significantly raised the standards of English hymnody, enriching and rejuvenating an important national music tradition.” Adams, 106. 


\begin{tabular}{|c|c|c|}
\hline VI. & $\begin{array}{l}\text { And there were in the same country shepherds abiding in the field, keeping } \\
\text { watch over their flock by night. And, lo, the angel of the Lord came upon } \\
\text { them, and the glory of the Lord shone round about them: and they were } \\
\text { sore afraid. And the angel said unto them, "Fear not: for, behold, I bring } \\
\text { you good tidings of great joy, which shall be to all people. For unto you is } \\
\text { born this day in the city of David a saviour, which is Christ the Lord. And } \\
\text { this shall be a sign unto you; ye shall find the babe wrapped in swaddling } \\
\text { clothes, lying in a manger,"And suddenly there was with the angel a } \\
\text { multitude of the heavenly host praising God, and saying,"Glory to God in } \\
\text { the highest, and on earth peace, good will toward men. We praise thee, we } \\
\text { bless thee, we worship thee, we glorify thee, we give thanks to thee for thy } \\
\text { great glory; O Lord God, heavenly King, God the Father Almighty."'Let } \\
\text { us now go even unto Bethlehem, and see this thing which is come to pass, } \\
\text { which the Lord hath made known unto us."And the shepherds came with } \\
\text { haste, and found Mary, and Joseph, and the babe lying in a manger. And } \\
\text { when they had seen it, they made known abroad the saying which was told } \\
\text { them concerning this child. And all they that heard it wondered at those } \\
\text { things which were told them by the shepherds. }\end{array}$ & $\begin{array}{l}\text { Adapted by } \\
\text { composer from } \\
\text { Luke } 2: 8-18 \text {, } \\
\text { and the Book of } \\
\text { Common Prayer }\end{array}$ \\
\hline VIII. & $\begin{array}{l}\text { And the shepherds returned, glorifying and praising God for all the things } \\
\text { that they had heard and seen, as it was told unto them. }\end{array}$ & From Luke 2:20 \\
\hline $\mathbf{X}$. & But Mary kept all these things, and pondered them in her heart. & From Luke 2:19 \\
\hline XIII. & $\begin{array}{l}\text { Now when Jesus was born, behold, there came wise men from the east } \\
\text { saying "Where is he that is born King? for we have seen his star in the east, } \\
\text { and are come to worship him." And they said unto them, "In Bethlehem." } \\
\text { When they had heard that they departed; and, lo! The star, which they saw } \\
\text { in the east, went before them, till it came and stood over where the young } \\
\text { child was. When they saw the star, they rejoiced with exceeding great joy. } \\
\text { And when they were come into the house, they saw the young child with } \\
\text { Mary his mother, and fell down and worshipped him; and when they had } \\
\text { opened their treasures, they presented unto him gifts; gold, and } \\
\text { frankincense, and myrrh. }\end{array}$ & $\begin{array}{l}\text { Adapted from } \\
\text { Matthew } 2: 1-2 \text {, and } \\
11\end{array}$ \\
\hline
\end{tabular}

\section{Poetic Insertions}

It has been observed that "Hodie employs a sprawling libretto and has been called an 'anthology' work of the kind Britten and Vaughan Williams made their own." ${ }^{18}$ Vaughan Williams was interested in contemporary literature in English from his own lifetime, and thus used various poems by many English poets, including Dante Gabriel Rossetti, Alfred Edward Housman, Bertrand Russell, and exceptionally Walt Whitman, the American poet, ${ }^{19}$ in his vocal

${ }^{18}$ Borton, 17.

19 "Whitman's ability to maintain a balance (however precarious) between the transcendent and the commonplace, and his insistence on the honest expression of vast, oceanic emotions, must have seemed particularly 
and choral works. Alain Frogley has remarked that "Hodie also underscores Vaughan Williams's lifelong involvement with English literary as well as musical tradition, particularly the glories of seventeenth-century poetry and prose, here represented by Milton, Herbert, Drummond, and the King James Bible (the last a perennial source of inspiration to the composer). ${ }^{20}$ In addition, Hodie not only included a poem by the English monk Miles Coverdale and an anonymous sixteenth-century poem attributed to William Ballet, but also a contemporary poem by Thomas Hardy. ${ }^{21}$ The poems were inserted between Narrations to embellish the meanings of the Narrations. Ursula assisted her husband in choosing the texts as well as by writing two poems for Hodie, 'The March of the Three Kings' and the second verse of 'No sad thought his soul affright. ${ }^{, 22}$ Unlike the Narrations, the poetic insertions are scored for various combinations of soloists, choirs, and instruments, reflecting expressiveness and diversity in style. Michael Kennedy remarks that "each poem called forth the type of music it required so that there is no sense of uneven invention, and the general effect is of a surpassingly happy lyrical flow of melody. ${ }^{, 23}$ The list of the poems is as follows:

\footnotetext{
attractive to a young composer in $1892 \ldots$ By drawing texts from Whitman for his first important large-scale choral works, Vaughan Williams was able to express a yearning for transcendence unmarked by conventional religious associations, and he could articulate as well the fiercely democratic convictions that he and the poet held in common...Reading Whitman may also have helped Vaughan Williams conceptualize the particular kind of cultural nationalism that he fervently promoted in his own career." Adams, 104-5.

${ }^{20}$ Frogley, 3.

${ }^{21}$ Etter, 49 .

${ }^{22}$ Frogley, 4.

${ }^{23}$ Michael Kennedy. The Works of Ralph Vaughan Williams. London: Oxford University Press, 1964: 364.
} 
Table 2.2 The List of the Poems

\begin{tabular}{|c|c|c|c|}
\hline \multicolumn{2}{|c|}{ Movement } & The Source of the Texts & Title \\
\hline I. & Prologue & Vespers for Christmas Day & Hodie Christus natus est \\
\hline III. & Song & John Milton & Hymn on the Morning of Christ's Nativity \\
\hline V. & Choral & $\begin{array}{l}\text { Miles Coverdale } \\
\text { after Martin Luther }\end{array}$ & The blessed son of God only \\
\hline VII. & Song & Thomas Hardy & The Oxen \\
\hline IX. & Pastoral & George Herbert & Christmas \\
\hline XI. & Lullaby & $\begin{array}{l}\text { Anonymous } \\
\text { (William Ballet) }\end{array}$ & Sweet was the song the Virgin sang \\
\hline XII. & Hymn & William Drummond & Bright portals of the sky \\
\hline XIV. & March & Ursula Vaughan Williams & The March of the Three Kings \\
\hline $\mathbf{X V}$. & Choral & $\begin{array}{l}\text { Anonymous and Ursula } \\
\text { Vaughan Williams }\end{array}$ & No sad thought his soul affright \\
\hline XVI. & Epilogue & $\begin{array}{l}\text { Adapted from the Bible } \\
\text { and John Milton }\end{array}$ & $\begin{array}{l}\text { Words from bible (John 1:1, 4, } 14 \text { and } \\
\text { Matthew 1: 23) and } \\
\text { Hymn on the Morning of Christ's Nativity }\end{array}$ \\
\hline
\end{tabular}

\section{Prologue}

The 'Prologue,' the first movement of Hodie, is taken from the Anglican liturgy for

Christmas Vespers. It presented the "celebration of a Saviour's birth, carolled by us along with choirs of angels and archangels, with a pristine immediacy that is of the earth, earthy."24

Originally, the texts were written in Latin, but Vaughan Williams translated them into an English version for people wishing to sing. ${ }^{25}$ The text of the movement is as follows:

${ }^{24}$ Mellers, 210.

${ }^{25}$ Vaughan Williams "states in the score, 'the English words may be sung at the discretion of the conductor, but the composer would much prefer the Latin.” Etter, 81. 
Table 2.3 The Text of 'Prologue'

Original Version

Nowell! Nowell! Nowell!

Hodie Christus natus est: hodie salvator apparuit:

Hodie in terra canunt angeli, laetantur archangeli:

Hodie exultant justi, dicentes: Gloria in excelsis Deo: Alleluia.

English Version

Nowell! Nowell! Nowell!

Christmas Day, Christ was born on Christmas Day.

Christmas Day, our Saviour was born on Christmas Day.

Christmas Day, on earth are angels singing, archangels rejoicing.

Christmas Day, rejoice ye just men, saying, Glory to God in the highest: Alleluia.

\section{Song}

'Song,' the third movement, is sung by the soprano soloist and orchestra, excerpted from the Hymn on the Morning of Christ's Nativity by John Milton (1608-1674), an English poet and writer of prose. ${ }^{26}$ The Hymn On the Morning of Christ's Nativity was written in 1629 and published in 1645 by the poet "after celebrating reaching the age of maturity in England, in commemoration of Christ's birth. ${ }^{, 27}$ The poem is based on a profound religious philosophy associated with birth of Jesus Christ that emphasized, "the cosmic significance of the

\footnotetext{
26 "He was educated at St. Paul's School, then at Christ's College, Cambridge, where he began to write poetry in Latin, Italian, and English, and prepared to enter the clergy. After university, however, he abandoned his plans to join the priesthood and spent the next six years in his father's country home in Buckinghamshire following a rigorous course of independent study to prepare for a career as a poet. His extensive reading included both classical and modern works of religion, science, philosophy, history, politics, and literature. In addition, Milton was proficient in Latin, Greek, Hebrew, French, Spanish, and Italian, and obtained a familiarity with Old English and Dutch as well." Academy of American Poets. "John Milton.” Poets. Org. http://www.poets.org/poet.php/prmPID/707 [accessed July 26, 2013].

${ }^{27}$ Thomas Corns. "'On the Morning of Christ's Nativity,' 'Upon the Circumcision.' and 'The Passion'” in $A$ Companion to Milton. Edited by Thomas Corns. Oxford: Blackwell Publishing, 2003: 216.
} 
incarnation," rather than the celebration of the birth, ${ }^{28}$ in a style of "seventeenth-century poetry

which typically fuses sophisticated post-Renaissance artifice with a dewy morning

atmosphere." ${ }^{, 29}$ The poem described "the triumph of Christ over Satan and the Pagan gods

(associated with darkness and discord), which will lead to his victorious death and resurrection.

This victory is accomplished at Christ's birth, with infant being 'associated with light, harmony, and the union of divine and human natures." ${ }^{, 30}$ Etter explains that:

Milton encapsulates the poem stating that it resonates of the "heavendescended King, the bringer of peace, and the blessed times promised in the sacred books.' He would compose a parallel poem to his 'Nativity Hymn' the following Easter, 'The Passion' which was left unfinished. In between these two was a brief ode, 'Upon the Circumcision' giving a trilogy of the events of Jesus' life. ${ }^{31}$

The poem, consisting of two hundred forty-four lines, is divided into two sections, the introduction and hymn, but Vaughan Williams only chose the hymn for Hodie. ${ }^{32}$ The introduction contains four stanzas and seven lines each, while the hymn has twenty-seven stanzas each eight lines long.

\footnotetext{
28 "Most believe that Milton expected the poem to be read in the tradition of Virgil's fourth ecologue, 'which heralds the return of the Golden Age under Augustus and associates it with the birth of a child' However, Milton's appropriation of classical elements is not pagan. As Woodhouse goes on to explain, "through many centuries of the Christian era Virgil's poem was interpreted as an unconscious prophecy of the birth of Christ." A. S. P. Woodhouse and Douglas Bush, eds. A Variorum Commentary on The Poems of John Milton Vol. 2. New York: Columbia University Press, 1972.

${ }^{29}$ Mellers, 212.

${ }^{30}$ Etter, 55-6.

${ }^{31}$ Etter, 54.

32 "Vaughan Williams does not set the entire 244 lines in Hodie, but brings together only the stanza he desires. One observation to be made is the parallel structure between the cantata and Milton's poem." Etter, 56.
} 
Vaughan Williams's choice of the texts in the 'Song' was brought on by the recent experiences of two world wars. ${ }^{33}$ It reflected his hope against skepticism and pessimism by using “Milton's allusion of peace brought by the Christ child, after whose birth 'no war, or battle's sound, was heard the world around." ${ }^{34}$ The text of the movement is as follows:

Table 2.4 The Text of the 'Song'

It was the winter wild,

While the Heaven-born child,

All meanly wrapt, in the rude manger lies;

Natural in awe to him

Had doff'd her gaudy trim,

With her great Master so to sympathize.

And waving wide her myrtle wand,

She strikes a universal peace through sea and land.

No war, or battle's sound,

Was heard the world around:

The idle spear and shield were high uphung;

The hooked chariot stood

Unstain'd with hostile blood;

The trumpet spake not to the armed throng;

And kings sate still with aweful eye,

As if they surely knew their Sovran Lord was by.

But peaceful was the night,

Wherein the Prince of light

His reign of peace upon the earth began:

The winds, with wonder whist,

Smoothly the waters kiss'd

Whispering new joys to the mild ocean,

Who now hath quite forgot to rave,

While birds of calm sit brooding on the charmed wave.

${ }^{33}$ Vaughan Williams served in World War I as well as World War II both in the military and as a civilian. Etter, 57.

${ }^{34}$ Etter, 57. 


\section{Choral}

For the fifth movement, Vaughan Williams chose words adapted by Miles Coverdale (1488-1569), an English Monk and one of the translators for the Tudor Bible. The 'Choral' ${ }^{35}$ is a four-part homophonic carol, ${ }^{36}$ scored for mixed choir without any instrumental accompaniment. Although Mellers believed that “... the music is Vaughan Williams's own, the carol serves exactly the same function as a 'traditional' chorale in a Bach Passion, relating the sacred story to us the people. ${ }^{, 37}$ Originally, it was written by Martin Luther (1483-1546), but translated later into English by Coverdale. The poem described "God's mercy brought by the Christ child, who would exchange his swaddling cloth with our own fleshly sins so we could fully receive that mercy." ${ }^{38}$ It consists of seven stanzas, but the composer chose just three for this movement. Vaughan Williams suitably set the poem by repeating the same word at the end of the three stanzas, 'Kyrieleison' ('Lord, have mercy') which is part of the Latin Mass. The text of the movement is as follows:

Table 2.5 The Text of the 'Choral'

The blessed son of God only

In a crib full poor did lie;

With our poor flesh and our poor blood

Was clothed that everlasting good.

Kyrieleison.

The Lord Christ Jesu, God's son dear, Was a guest and a stranger here;

Us for to bring from misery,

\footnotetext{
${ }^{35}$ The title of the poem written by Martin Luther is "Gelobet seist du." Etter, 58.

${ }^{36}$ Mellers, 212.

${ }^{37}$ Mellers, 212-3.

${ }^{38}$ Etter, 59.
} 
That we might live eternally.

Kyrieleison.

All this did he for us freely,

For to declare his great mercy;

All Christendom be merry therefore,

And give him thanks for evermore.

Kyrieleison.

\section{The Oxen}

'The Oxen,' the seventh movement scored for baritone soloist and orchestra, was taken from 'The Oxen' by Thomas Hardy (1840-1928), an English novelist and poet. ${ }^{39}$ Hardy's poems had been described as "satires of circumstance," 40 and presented a pessimistic view associated with a past or lost love after the death of his wife in $1912 .{ }^{41}$ Hardy composed 'The Oxen' in 1915 after World War I (WWI) had begun, and it was published in 1917 in Moments of Vision, a collection of his poetry. ${ }^{42}$ It has been described as "a poignant lament for lost faith" ${ }^{43}$ which reflected Hardy's agnosticism. Adams stated that it is "a cry for the innocent faith of childhood from a speaker who has lost it, and experienced all the attendant pain and uncertainly that comes in the wake of that loss. By choosing this poem, Vaughan Williams clearly allies himself with

39 "'Hardy's poetry explores a fatalist outlook against the dark, rugged landscape of his native Dorset. He rejected the Victorian belief in a benevolent God, and much of his poetry reads as a sardonic lament on the bleakness of the human condition. A traditionalist in technique, he nevertheless forged a highly original style, combining rough-hewn rhythms and colloquial diction with an extraordinary variety of meters and stanzaic forms. A significant influence on later poets (including Frost, Auden, Dylan Thomas, and Philip Larkin), his influence has increased during the course of the century, offering an alternative - more down-to-earth, less rhetorical - to the more mystical and aristocratic precedent of Yeats." Academy of American Poets. "Thomas Hardy." Poets. Org. http://www.poets.org/poet.php/prmPID/707 [accessed August 5, 2013].

${ }^{40}$ Mellers, 213.

${ }^{41}$ Etter, 62.

${ }^{42}$ Etter, 62.

${ }^{43}$ Frogley, 5. 
Hardy, whose lost childhood faith was not replaced by adult belief."44 'The Oxen' reflected Hardy's religious philosophy, that is, his disbelief in superstition and in Christian faith. Etter pointed out that "the poem may have been written in response to the European slaughter in WWI, destroying his belief in the gradual ennoblement of man and reinforcing his doubt in an omnibenevolent God. He attacks the belief in this kind of God by exemplifying the absurdity of annually marveling at kneeling oxen, which is emphatically out of vogue..." ${ }^{, 45}$ Nevertheless, Vaughan Williams chose ‘The Oxen' for this Christmas cantata with its joyous celebration of Christmas. Mellers believed that "the seventh movement is a little miracle, the emotional core of the work. There is point in this since Thomas Hardy's poem, recounting an old folk legend that on Christmas Eve the cattle in their 'strawy pen' are wont to kneel in homage to the newborn Son of God, encapsulates Vaughan Williams's approach to the Christ Mass."46

The poem was comprised of four stanzas of four lines each, and Vaughan Williams used the entire poem for this movement. Ursula Vaughan Williams was engaged in the choice of the texts for this movement.

However, the Hardy poem was first selected by Ursula and only later accepted by Vaughan Williams; in recent correspondence she writes, 'I chose the Hardy poem, because I liked it, not for any spiritual reasons. Ralph liked it very much too.' Therefore, the various theories, which imply that Vaughan Williams specifically chose this poem for spiritual reasons, would seem to be erroneous, particularly since it was Ursula who placed it in the libretto from the outset. Why Vaughan Williams liked the poem is a matter for speculation. One possibility

\footnotetext{
${ }^{44}$ Adams, 116.

${ }^{45}$ Etter, 62-3.

${ }^{46}$ Mellers, 213.
} 
might be that there was an unconscious awareness of the connection between his beliefs and that of Hardy's poem. ${ }^{47}$

In article, she wrote that "'The Oxen,' Hardy's poem, comes a little earlier in the work. The setting, for baritone, is as direct as the words." 48 The text of the movement is as follows:

Table 2.6 The Text of the 'The Oxen'

Christmas Eve, and twelve of the clock.

"Now they are all on their knees,"

And elder said as we sat in a flock

By the embers in hearth side ease.

We pictured the meek mild creatures where

They dwelt in their strawy pen,

Nor did it occur to one of us there

To doubt they were kneeling then.

So fair a fancy few would weave

In these years! Yet, I feel

If someone said on Christmas Eve,

"Come; see the oxen kneel,

In the lonely barton by yonder coomb

Our childhood used to know,"

I should go with him in the gloom,

Hoping it might be so.

\section{Pastoral}

For this ninth movement of Hodie, Vaughan Williams chose a poem, titled 'Christmas' by George Herbert (1593-1633), a poet whose poetry reflects "themes such as the nature of the soul, salvation, sin, and redemption." ${ }^{49}$ Herbert wrote the poem just before his death, and it was

\footnotetext{
${ }^{47}$ Etter, 64.

${ }^{48}$ Ursula Vaughan Williams, 88.

${ }^{49}$ Etter, 65.
} 
published along with other poems in 1633 in The Temple, a collection of "religious poetry

mapping the life of Herbert grappling with the issue of God's character being harsh and

silent... 'Christmas' occurs in the sequence at a spiritual low point, when the narrator feels that

his 'feeble spirit...' Like a nipt blossome, [hangs]/ Discontented."50

The poem consists of two parts, but only the second part was used for Hodie, and then it was titled 'Pastoral.' 51

...the complete poem presents the narrator as a traveler coming to the first available inn, where Christ happens to be staying. He has been seeking pleasures, but now realizes his worthlessness, and how this child deserves a better place than a manger to lay his head. The second half of the poem, which Vaughan Williams sets to music, begins in a repentant tone... using metaphor to bring the visitor back from the seeking of pleasures to prayer and praise of God. This poem shows a bit of the honest struggle so customary in Herbert's work. ${ }^{52}$

The 'Pastoral' was scored for baritone soloist and orchestra, and has been described as a prayer and praise to the Christ child.

This beautiful song, however, penetrates to Herbert's essence, reflecting the poem's discreet sensuality, domestic wit and ultimate transcendence when the candle is metamorphosed into a sun which, although 'frost-nipt,' is a 'willing shiner.' Vaughan Williams responds adequately, which is saying a lot, to Herbert's fusion of the metaphors of singing a shining: the sun's 'beams shall cheer my breast, and both so twine that even his beams sing, and my music shine. ${ }^{53}$

${ }^{50}$ Etter, 65.

51 'Herbert's poems sometimes take a double-poem organization with two separate stanza forms. Because he played the lute and was familiar with popular songs of his day, he may have adapted this two-part structure. He may even have intended the poems to be sung." Christian Classics Ethereal Library. "From The Temple (1633), by George Herbert." http://www.ccel.org/h/herbert/temple/Christmas.html [accessed July 28, 2013 ].

${ }^{52}$ Etter, 65-6.

${ }^{53}$ Mellers, 214. 
The text of the movement is as follows:

Table 2-7 The Text of the 'Pastoral'

The shepherds sing; and shall I silent be?

My God, no hymn for thee?

My soul's a shepherd too: a flock it feeds

Of thoughts, and words, and deeds.

The pasture is Thy Word; the streams, Thy Grace

Enriching all the place.

Shepherd and flock shall sing, and all my powers

Out-sing the daylight hours.

Then we will chide the sun for letting night

Take up his place and right:

We sing one common Lord; wherefore he should

Himself the candle hold.

I will go searching, till I find a sun

Shall stay till we have done;

A willing shiner, that shall shine as gladly

As frost-nipt suns look sadly.

Then we will sing, and shine all out own day,

And one another pay;

His beams shall cheer my breast, and both so twine

Till even his beams sing, and my music shine.

\section{Lullaby}

The text of the eleventh movement of Hodie, 'Lullaby,' was taken from William Ballet's poem, 'Sweet Was the Song the Virgin Sang.' It was sometimes called 'Lutebook Lullaby,' with its name taken from Ballet's lute book written in $1594 .{ }^{54}$ It was scored for soprano soloist, women's choir, and orchestra, and was described as “Mary's care for Christ, who would become the ultimate caregiver for her and for mankind" with "a beautiful depiction of the picturesque setting of the Virgin and her savior/child." 55 According to Etter, "its poet is thought to be

\footnotetext{
${ }^{54}$ Etter, 67.

${ }^{55}$ Etter, 69.
} 
anonymous, however Vaughan Williams credits the source in the score as William Ballet,"56 a late sixteenth-century English lutenist and lute song composer. The poem was also set by John Attey in $1622 .^{57}$ Although the two composers used the same poem in their works, slight differences exist. Etter argues that:

If Ballet or Attey is the poet, it would place the author roughly as a contemporary with Herbert...Herbert's language has a more contemporary, straightforward sound, while this author's is more archaic, even for its time. Such terms 'eke' (meaning 'also' or 'moreover') and 'lulla, lulla-bye' come from the medieval era, during which anonymous poets used the expressions 'lulla-bye' and 'lalula-bye' in Christ child poems. This gives weight to the belief that it is the work of an anonymous poet, perhaps before Ballet or Attey's time. ${ }^{58}$

The text of the movement is as follows:

Table 2.8 The Text of the 'Lullaby'

Sweet was the song the Virgin sang, When she to Bethlem Juda came

And was delivered of a son, That blessed Jesus hath to name.

"Lulla, lulla, lulla-bye," "Sweet babe," sang she, And rocked him sweetly on her knee.

"Sweet babe," sang she, "my son,"

${ }^{56}$ Etter, 67.

57 "The English school of lute song composers represents some of the most famous English composers of all time... The last composer of a printed book of lute songs, John Attey, was decidedly less capable than his predecessors. Published in 1622, his First Booke of Ayres was also his last, and he demonstrated a distinct lack of familiarity with writing for the lute (several of the lute parts had notes written outside the range of the instrument), so caution is required in editing his music for performance." Michelle Oswell. "The $17^{\text {th }}$ Lute Song Composers." The Printed English Lute Song in $17^{\text {th }}$ century England. http://www.pages.drexel.edu/ mlo26/composers.html [accessed August 6, 2013].

"Ursula Vaughan Williams, perusing her collection of poetry books fifty years after the first performance of Hodie, found this text in Fellows, English Madrigal Verse, 1588-1632, which attributes the text to Attey in 1622." Etter, 67.

${ }^{58}$ Etter, 68-9. 
And eke a saviour born,

Who hast vouchsafed from on high

To visit us that were forlorn:

Lalula, lalula, lalula-bye,"

"Sweet babe," sang she,

And rocked him sweetly on her knee.

\section{Hymn}

The poem, 'Bright Portals of the Sky' by William Drummond of Hawthornden (1585-

1649), a Scottish poet, ${ }^{59}$ was used for the twelfth movement. It was "first printed in the second edition of Drummond's Flowres of Sion (1630), though the exact date of production is

uncertain." ${ }^{60}$ It was scored for tenor soloist and orchestra, and described 'the triumph of

Christ. ${ }^{61}$ Mellers comments that

it makes more of the scale's whole-tone implications, tending towards an exoticism that matches Drummond's ornate rhetoric. The effect, evoking 'bright portals of the sky,' 'sparkling stars' and 'the doors of eternity,' is appropriately magical, and magic instruments...In context the hymn is cannily placed, for it introduces the most extended dramatic, and pictorial, episode in the cantata: the visit of the Wise Men from the East. ${ }^{62}$

It consists of "fourteen stanzas of eight lines each with an additional two lines at the end," but "only stanzas one (the gates of heaven), four (addressing the absent Christ), and fourteen (the climax of the poem) were used." ${ }^{, 63}$ After the first play-through of Hodie, several stanzas from this

${ }^{59}$ Etter, 70.

${ }^{60}$ Etter, 70 .

${ }^{61}$ Although Vaughan Williams selected the poem for the Christmas cantata, it did not refer to 'the birth of Christ.'

${ }^{62}$ Mellers, 215-6.

${ }^{63}$ Etter, 71. 
poem were added for Eric Greene who was a soloist at the first performance. ${ }^{64}$ This movement is different from the other solo songs of Hodie in terms of mood and manner. The text of the movement is as follows:

Table 2.9 The Text of the 'Hymn'

Bright portals of the sky

Emboss'd with sparkling stars,

Doors of eternity

With diamantine bars,

Your arras rich uphold,

Loose all your bolts and springs,

Ope wide your leaves of gold,

That in your roofs may come the King of Kings.

O well-spring of this All!

Thy father's image vive;

Word, that from naught did call

What is, doth reason, live;

The soul's eternal food,

Earth's joy, delight of heaven;

All truth, love, beauty, good:

To thee, to thee be praises ever given!

O glory of the heaven!

O sole delight of earth!

To thee all power be given,

God's uncreated birth!

Of mankind lover true,

Indearer of his wrong,

Who dost the world renew,

Still be thou our salvation and our song!

${ }^{64}$ Ursula stated that "The bravura 'Bright portals of the sky' by Drummond was a number added after the first play-through, for Eric Greene, who sang at the first performance. 'If I'm to be an archangel,' said Eric, 'can't I, please, have a little more to do." Ursula Vaughan Williams, 88. 


\section{The March of The Three Kings}

The text of 'The March of The Three Kings,' the fourteenth movement of Hodie, was written by Ursula Vaughan Williams (1911-2007), an English poet, author, and librettist, as well as Ralph Vaughan Williams's second wife. She not only assisted in the selection of texts for Vaughan Williams's large-choral works, but also wrote librettos for many of them. She reminisced that:

I think I am the only remaining contemporary whose words he used. My position was, in a way, special, because for many years I was available for any job he wanted, from finding another suitable verse from Shelley for wartime songs, to writing a big solo for Lord Lechery in Vanity Fair, of Pilgrim's Progress, for providing words for a cantata for school-children, or a Three Kings episode for Hodie when neither of us could find any available existing verse that fitted...But I began to understand - and this is as difficult to define as an elephant - what is the special quality of 'settability' that a composer wants in an anthology work, or opera, how it must fit in with the other texts - and, again, how it must be suited to the kind of music it was for - flamboyant, for instance, for Lord Lechery, romantic and mysterious for the Three Kings. But, in this matter of words, I liked it best when he set words of mine he liked, that were already written or printed. ${ }^{65}$

The poem, described as 'the journey of the Magi (the three kings),' celebrates the birth of

Christ. That is to say, the kings found the exceptionally twinkling and moving star from far away at that night. So, they followed it, and then stopped where the star stopped above a stable. They entered in the stable, and then found a baby in a manger. They realized the baby would be the King, our Saviour. After the kings adored the baby, they gave him gifts of gold, frankincense, and myrrh. It has been observed that "the Magi's gifts were symbolic as well as valuable; gold represented Christ's kingly nature; fragrant resin of frankincense, used by the Hebrews in their worship of God, signified Christ's worthiness of worship; symbolic of death, myrrh was a burial

\footnotetext{
${ }^{65}$ Ursula Vaughan Williams, 87.
} 
ointment. Consequently, the magi's visit was a pre-emptive preparation for Christ's death and entombment, a foreshadowing of his purpose. ${ }^{.66}$ Mellers also stated that the poem presented "the interdependence of life and death, and ends with a vision of the 'star of dayspring' whose 'sharp radiance lights the stable and the broken walls.",67

The movement is scored for soprano, tenor, baritone soloists, mixed choir, and orchestra. "The baritone sings of the gold, the tenor of the frankincense, and the soprano of the myrrh," while the men's choir symbolically sings of the Magi and the mixed choir sings of the majesty of the Christ child. ${ }^{68}$ The text of the movement is as follows:

Table 2.10 The Text of the 'The March of The Three Kings'

From kingdoms of wisdom secret and far Come Caspar, Melchior, Balthasar; They ride through time, they ride through night led by the star's foretelling light.

Crowning the skies the star of morning, star of dayspring calls, lighting the stable and the broken walls where the prince lies.

Gold from the veins of earth he brings, red gold to crown the King of Kings. Power and glory here behold shut in a talisman of gold.

Frankincense from those dark hands was gathered in eastern, sunrise lands, incense to burn both night and day to bear the prayers a priest will say.

\footnotetext{
${ }^{66}$ Etter, 74.

${ }^{67}$ Mellers, 216.

${ }^{68}$ Etter, 74.
} 
Myrrh is a bitter gift for the dead.

Birth but begins the path you tread;

your way is short, your days foretold

by myrrh and frankincense and gold.

Return to kingdoms secret and far,

Caspar, Melchior, Balthasar,

Ride through the desert, retrace the night

leaving the star's imperial light.

Crowning the skies

the star of morning, star of dayspring, calls:

clear on the hilltop its sharp radiance falls

lighting the stable and the broken walls

where the prince lies.

\section{Choral}

The fifteenth movement, the 'Choral' is scored for a cappella singing of a strophic

hymn-like setting, and is divided into two stanzas. The text of the first part was taken from an anonymous poem, and the text of the second part was a newly written poem by Ursula Vaughan Williams, as requested by the composer. The first stanza presented "a third-person view of the Christ child and the Magi, who offer joy to the Child waking up in a world of fallen men, who receive hope because of the Christ child's presence." 69 The second stanza was matched with the first stanza in terms of "feet, syllables (all lines are seven syllables long with the exception of line six which is eight), rhyme, and overall theme." ${ }^{70}$ It is a poem of praise and joy at the birth of the Jesus. The text of the movement is as follows:

\footnotetext{
${ }^{69}$ Etter, 75.

${ }^{70}$ Etter, 74.
} 
Table 2.11 The Text of the 'Choral'

No sad thought his soul affright;

Sleep it is that maketh night;

Let no murmur nor rude wind

To his slumbers prove unkind;

But a quire of angels make

His dreams of heaven, and let him wake

To as many joys as can

In this world befall a man.

Promise fills the sky with light,

Stars and angels dance in flight;

Joy of heaven shall now unbind

Chains of evil from mankind,

Love and joy their power shall break,

And for a new born prince's sake;

Never since the world began

Such a light such dark did span.

\section{Epilogue}

For the last movement of Hodie, Vaughan Williams set the words taken from the bible along with Milton's Hymn on the Morning of Christ's Nativity which had already been used in the third movement of the work. He chose different stanzas of the poem for the last movement, with the instrumentation and musical style different from the third movement. Table 2-12 presents the comparison of the third and sixteenth movements of Hodie in terms of the texts.

Table 2.12 The Comparison of The Third and Sixteenth Movements of Hodie

\begin{tabular}{|c|c|c|}
\hline & The Third Movement & The Sixteenth Movement \\
\hline Source & \multicolumn{2}{|c|}{ Three stanzas from the Milton's poem } \\
\hline Form & $\begin{array}{c}\text { The first six lines of stanza } 1 \\
\text { The last two lines of stanza } 3 \\
\text { Stanzas } 4 \text { and } 5\end{array}$ & $\begin{array}{c}\text { (The scripture) } \\
\text { Stanza } 13 \\
\text { Stanza } 12 \\
\text { Stanza } 15\end{array}$ \\
\hline $\begin{array}{l}\text { Performing } \\
\text { Forces }\end{array}$ & $\begin{array}{l}\text { The soprano soloist, women's } \\
\text { choir, and orchestra. }\end{array}$ & $\begin{array}{l}\text { The soprano, tenor, } \\
\text { baritone soloists, mixed } \\
\text { choir, and orchestra. }\end{array}$ \\
\hline
\end{tabular}


The greatness of God who created the heavens and the earth emerges as the theme of the biblical and non-biblical texts that were aptly chosen and mingled in the last movement. Significantly, with this compositional strategy, Vaughan Williams recreates his textual sources and conveys new meanings.

This gives his ending a two-fold implication, the first praising and rejoicing the fact that Christ came to save the world and give it peace, and the second communicating Vaughan Williams's religious views of a world that can find its harmony through music, which was his religion more than Christianity. ${ }^{71}$

The text of the movement is as follows:

Table 2.13 The Text of the 'Epilogue'

In the beginning was the Word, and the Word was with God, and the Word was God. In Him was life; and the life was the light of men. And the Word was made flesh, and dwelt among us, full of grace and truth. Emmanuel, God with us.

Adapted from John i. 1-14.

Ring out, ye crystal spheres,

Once bless our human ears,

If ye have power to touch our senses so;

And let your silver chime

Move in melodious time,

And let the bass of heaven's deep organ blow;

And, with your ninefold harmony,

Make up full consort to the angelic symphony.

Such music (as 'tis said),

Before was never made,

But when of old sons of morning sung,

While the Creator great

His constellations set,

And the well-balanced world on hinges hung;

And cast the dark foundations deep,

And bid the weltering waves their oozy channel keep.

Yea, truth and justice then

\footnotetext{
${ }^{71}$ Etter, 57.
} 
Will down return to men,

Orbed in a rainbow; and, like glories wearing,

Mercy will sit between,

Throned in celestial sheen,

With radiant feet the tissued clouds down-steering;

And heaven, as at some festival,

Will open wide the gates of her high palace hall.

From Hymn on the Morning of Christ's Nativity

\section{The Relationships of Biblical and Non-biblical Texts in Vaughan Williams's Other Works}

Vaughan Williams's practice of combining and manipulating texts reflects one of his most important compositional methods. For his large choral works, he freely stripped out certain biblical texts, and chose from various literary sources, including poetry from the sixteenth to twentieth century, as well as social or political commentary. By combining biblical and nonbiblical texts, he not only recreated new meanings obtained by rearranging original sources, such as scriptures, various poems, and writings, but also revealed his own thoughts and religious

philosophy as well as ideas about English nationalism. Adams proposes that:

Vaughan Williams not only arranged biblical passages in order that the symbolism of the text coincided with the symbolic import of his aesthetic purpose, he also on occasion employed the expressive qualities of his music in order to construe the words in a manner quite contrary to their orthodox interpretation. By careful choice of musical idiom he deconstructs the text, shattering its original import to bits in order to rebuild it closer to his heart's desire; in other words, in such works it is the music itself, rather than textual manipulation, which is used to place both composer and listener at a remove from the literal meaning of a biblical text. ${ }^{72}$

\footnotetext{
${ }^{72}$ Adams, 114.
} 
Sancta Civitas (1926) and Dona Nobis Pacem (1934 -1936), like Hodie, are typical of Vaughan Williams's large choral works, and combine biblical and non-biblical texts. Thus, they may be considered typical of Vaughan Williams's compositional technique. However, Vaughan Williams combined the texts in different ways in each work. For Sancta Civitas, Vaughan Williams carefully obtained verses from two versions of the bible and then rearranged them as he desired. Composed after World War I, the texts of Sancta Civitas described "the sadness and the suffering of a whole generation that had lost its innocence,",73 and ultimately alluded to "life after death... and its vision is of the Holy City, where we hope to dwell with God." ${ }^{, 74}$ Sancta Civitas has also been described as "a symbolic statement concerning the survival of the soul after death." ${ }^{, 75}$ Adams believed that:

By employing this excerpt, the composer clearly sets aside a Christian interpretation of the biblical text that follows, while pointing towards a reason for its selection. While the inscription from Plato is meant to distance the composer from the literal meaning of the biblical passages he has chosen, it also serves to guide performers and listeners of Sancta Civitas towards his symbolic intent. Part if the beauty of a living symbol is its inexhaustible potential for interpretation on multiple levels of meaning. By combining textural and musical symbolism, the composer gave his listeners the freedom to find their own meaning for both words and music. ${ }^{76}$

The texts of Dona Nobis Pacem were taken words from "the Roman liturgy, Whitman's Drum Taps, and a famous speech delivered by John Bright to the House of Commons in February 1855 at the height of the Crimean War, along with nine passages from the Old and New

\footnotetext{
${ }^{73}$ Simon Heffer. Vaughan Williams. Boston: Northeastern University Press, 2001: 66.

${ }^{74}$ Howes, 150.

${ }^{75}$ Adams, 112.

${ }^{76}$ Adams, 111.
} 
Testaments. ${ }^{, 77}$ Like Hodie, in Dona Nobis Pacem he chose scripture and poems with a social or political message, but placed them in a different way. As in Hodie, Vaughan Williams chose the juxtaposition of biblical and non-biblical texts with the non-biblical commentary supporting and enriching the biblical passages. Thus the relationship between two was interdependent. In Dona Nobis Pacem, however, there was no connection between biblical and non-biblical texts. The six movements of the work, on Latin words from the Eucharistical Agnus Dei, three poems by Whitman, Bright's speech, and nine passages from scriptures, were selected as needed without interdependence between movements as in Hodie. Therefore, the relationship between biblical and non-biblical texts was independent. Adams observes that:

Vaughan Williams's placement of this speech gives the biblical selections that follow a distinctly modern and secular implication. Set to joyous, extroverted music, the biblical fragments are manipulated so as to call for a political peace on earth, a call which is intensified by its proximity to Bright's somber reminder of the human cost of war in an age without miracles. This interpretation is at variance with the Bible verses in their original context, either the covenant promises which God made to the Israelites in the sections from the Old Testament (such s Micah 4:3) or the spiritual peace promised by the birth of Christ in the single verse chosen from the New Testament (Luke 2:14). ${ }^{78}$

Dona Nobis Pacem was sometimes called the anti-war cantata because it was related to his war experiences. Unlike Hodie, Vaughan Williams chose only poems by Whitman instead of other English poets. Ursula reminisced that:

He had gone back to Whitman for the text of most of Dona Nobis Pacem, a couple of years earlier, using poems that came from Whitman's experience in the American Civil War, parallel to his own in the Great War, and, though there is a final section of hope drawn from the Old Testament, 'Mercy and

\footnotetext{
${ }^{77}$ Adams, 115.

${ }^{78}$ Adams, 115-6.
} 
truth are met together, righteousness and peace have kissed each other', I think it was the historian in Ralph... who gave to the soprano soloist the last and desperate cry of 'Dona nobis pacem' with which the work ends. ${ }^{79}$

Because Vaughan Williams experienced war in his life, he tried to convey to audiences through the cantata "a warning that the unstable political situation of the 1930s was sliding disastrously towards another war." ${ }^{\prime 0}$ The work did not present a mournful dirge associated with WWI, but showed a pre-emptive lament concerning WWII yet to happen to the world. ${ }^{81}$ Thus, Vaughan Williams's earnest hope that war would never begin, was contained in the work. ${ }^{82}$ Adams comments that:

Forming the conclusion to the work, but placed immediately after Bright's speech, the biblical passages are used to express Vaughan Williams hope for a purely terrestrial peace on earth, rather than as a symbolic evocation of 'that which lies beyond sense and knowledge.' The section of Bright's speech used in Dona Nobis Pacem itself contains a biblical allusion, to the Passover story found in Exodus (12:21-3). ${ }^{83}$

This work is significant in the way that "Vaughan Williams anticipated by twenty-five years Britten's method in the War Requiem(1961-2) of interpolating English poems into the Latin Mass. $" 84$

${ }^{79}$ Ursula Vaughan Williams, 86.

${ }^{80}$ Andrew Burn. Dona nobis pacem and Sancta Civitas. CD Booklet. Naxos: Canada. 2010: 4.

${ }^{81}$ Heffer, 92.

82 "Vaughan Williams ends his cantata on a note of quiet urgency, as the soprano sings, alone and unaccompanied, the words 'Dona nobis pacem'; perhaps the composer's active participation in the Federal Union, organization that worked towards the creation of a united Europe, had given him an idea of how difficult it was (and is) to achieve even the most precarious "peace on earth." Adams, 116.

${ }^{83}$ Adams, 115.

${ }^{84}$ Michael Kennedy. The Works of Ralph Vaughan Williams. London: Oxford University Press, 1964: 254. 


\section{Conclusion}

The compositional method of the combining biblical and non-biblical texts had been used by many previous composers, but Vaughan Williams uniquely made it part of his own style, creating new meanings, often different from the original sources. Hodie, Vaughan Williams's last large-choral work, combines Biblical narration and Poetic insertion placed in juxtaposition. Thus, the relationship between the two was interdependent because the insertions supported the texts of the narrations and enriched the development of the story. The story, the celebration of the birth of Jesus Christ derived from the bible, was remade as if it was "an old tale that happened in the once upon a time. ${ }^{, 85}$ Furthermore, British cultural nationalism was reflected in the cantata by selecting poems by English poets from the sixteenth to the twentieth century. These characteristics had been presented in his previous large-choral works including Sancta Civitas and Dona Nobis Pacem although the combinational methods of the biblical and nonbiblical texts were different. Therefore, the treatment of the text was one of the compositional strategies unique to Vaughan Williams's style and an influence on the next generation including Benjamin Britten (1913-76).

\footnotetext{
${ }^{85}$ Mellers, 211.
} 


\section{Chapter 3. Recurring Themes in Narrations and Other Movements}

Vaughan Williams's unity of expression is assured by the solidity and clear expressiveness of the music. ${ }^{1}$ These motives and their use throughout Hodie help support the concept of unity in the cantata. ${ }^{2}$

Hodie presents Vaughan Williams's compositional facility in matching of the text and music using techniques that result in variety as well as unity. Variety can be found in the choice of various poems by many poets from the sixteenth to the twentieth centuries, while unity is achieved by the use of recurring themes to link the sixteen movements of the cantata. However, Vaughan Williams was criticized

for his lack of unity throughout the work, which admittedly was composed sectionally rather than developmentally, Vaughan Williams having resorted to styles of former compositions to help communicate his new work. This 'recycling' elicited much of the criticism. ${ }^{3}$

It was claimed that Hodie "also undoubtedly lacks unity of style, since certain parts ('The Oxen' and the boys' narration, for example) might have been - but were not - written thirty years earlier than other sections. ${ }^{44}$ Despite such criticisms, unity can be found in Hodie. It has been remarked that Vaughan Williams

\footnotetext{
${ }^{1}$ Homer Ulrich. A Survey of Choral Music. New York: Harcourt Brace Jovanovich, Inc., 1973: 206.

${ }^{2}$ Paul James Etter. "Ralph Vaughan Williams' "Hodie": An Analysis and Performance Guide for the Choral Conductor.” Ph.D., Texas Tech University, 2002. In ProQuest Dissertations and Theses, http://search.proquest.com/pqdtft/docview/305482745/13E44A9D9F9519F22FB/2?accountid=2837 [accessed May 26, 2013]: 115 .

${ }^{3}$ Etter, 77 .

${ }^{4}$ Michael Kennedy. The Works of Ralph Vaughan Williams. London: Oxford University Press, 1964: 364.
} 
...recalls musical phrases and motives throughout. Examples of this are the musical similarities between movements I, VI, and VIII; the angel motive found in movements II and VI; and the choral declaration of 'Emmanuel' in movements II and XVI...The narration, Gospel scripture sung by boys' voices, also links the work. It is always accompanied by organ only, in an unvarying style in each movement, and continues the storyline through the coming of the magi. These instances of unity may not satisfy every critic, but they refute the notion that no unity exists. ${ }^{5}$

Recurring musical themes in Hodie link Narrations and poetic insertions. With varied melodic and rhythmic figurations and changes in harmony and orchestration, the themes were reworked, shortened, lengthened, and combined with new themes. This chapter will introduce the recurring themes in Hodie, and through comparison examine how they are modified. Table 3.1 presents the entire list of recurring themes with their choral/solo forces in Narrations and other movements. Vaughan Williams used recurring themes in Narrations and several of the poetic insertions in different figurations, positions, and combinations. These skillful compositional techniques avoid the monotony of repetitive recurring themes.

Table 3.1 Recurring Themes in Hodie

\begin{tabular}{|c|c|c|}
\hline Movement & Recurring theme & Choral/Solo Forces \\
\hline Prologue & Gloria theme & Mixed choir \\
\hline Narration II & $\begin{array}{l}\text { Boy evangelists theme } 1 \\
\text { Blessing-curse theme } \\
\text { Alternating F sharp minor and F minor chords theme } \\
\text { Rising bass line theme } \\
\text { Fanfare theme } \\
\text { 'Emmanuel, God with us' theme }\end{array}$ & $\begin{array}{l}\text { Boy's choir, } \\
\text { Tenor solo } \\
\text { Tenor solo } \\
\text { Tenor solo } \\
\text { (Brass) } \\
\text { Mixed choir }\end{array}$ \\
\hline Narration IV & $\begin{array}{l}\text { Boy evangelists theme } 1 \\
\text { Boy evangelists theme } 2\end{array}$ & $\begin{array}{l}\text { Boy's choir } \\
\text { Boy's choir }\end{array}$ \\
\hline Narration VI & $\begin{array}{l}\text { Boy evangelists theme } 2 \\
\text { Blessing-curse theme } \\
\text { Rising bass line theme } \\
\text { Fanfare theme }\end{array}$ & $\begin{array}{l}\text { Boy's choir } \\
\text { Tenor solo } \\
\text { Tenor solo } \\
\text { (Brass) }\end{array}$ \\
\hline
\end{tabular}

\footnotetext{
${ }^{5}$ Etter, 77-8.
} 


\begin{tabular}{|c|c|c|}
\hline Narration VI & $\begin{array}{l}\text { Alternating } F \text { sharp minor and } F \text { minor chords theme } \\
\text { Gloria theme (An excerpt from 'Prologue') } \\
\text { Boy evangelists theme } 3\end{array}$ & $\begin{array}{l}\text { Tenor solo } \\
\text { Soprano solo and } \\
\text { mixed choir } \\
\text { Men's choir and boy's } \\
\text { choir }\end{array}$ \\
\hline Narration VIII & $\begin{array}{l}\text { Boy evangelists theme } 3 \\
\text { Gloria theme }\end{array}$ & $\begin{array}{l}\text { Boy's choir } \\
\text { Women choir }\end{array}$ \\
\hline Narration $\mathbf{X}$ & Boy evangelists theme 1 & Boy's choir \\
\hline Narration XIII & $\begin{array}{l}\text { Boy evangelists theme } 2 \\
\text { Boy evangelists theme } 3\end{array}$ & $\begin{array}{l}\text { Boy's choir, } \\
\text { men's choir, and } \\
\text { women's choir }\end{array}$ \\
\hline $\begin{array}{l}\text { The March of } \\
\text { the Three } \\
\text { Kings }\end{array}$ & $\begin{array}{l}\text { Blessing-curse theme } \\
\text { Fanfare theme }\end{array}$ & $\begin{array}{l}\text { Mixed choir } \\
\text { (Orchestra) }\end{array}$ \\
\hline $\begin{array}{l}\text { The first part of } \\
\text { Epilogue }\end{array}$ & $\begin{array}{l}\text { Alternating F sharp minor and F minor chords theme } \\
\text { Rising bass line theme } \\
\text { Blessing-curse theme } \\
\text { Fanfare theme } \\
\text { 'Emmanuel, God with us' theme }\end{array}$ & $\begin{array}{l}\text { (Orchestra) } \\
\text { Baritone solo } \\
\text { Tenor } \rightarrow \text { Soprano } \rightarrow \\
\text { Soprano, tenor, and } \\
\text { baritone solos } \\
\text { (Full orchestra) } \\
\text { Soprano, tenor, } \\
\text { baritone solos and } \\
\text { Mixed choir }\end{array}$ \\
\hline
\end{tabular}

\section{The Gloria Theme}

The Gloria theme ${ }^{6}$ is presented in the first movement. Alain Frogley comments that "the Gloria acclamations with which the Prologue movement ends return at various points in the cantata, and underline the central theme of wonder and worship."7 The Gloria theme also reappears in the sixth and eighth movements in a different key, with different harmony, length, and orchestration as indicated in table 3.2. Although the same theme is used in several movements, it is changed in content, length, choral forces, and dynamics, but not key.

${ }^{6}$ According to Etter, 86, the Gloria motive was first identified by A.E.F. Dickinson in Vaughan Williams. London: Faber\&Faber, 1963: 373.

${ }^{7}$ Alain Frogley. Vaughan Williams: Hodie (A Christmas Cantata). CD Booklet. Musical Heritage: London. 1990: 5 . 
Table 3.2 The Gloria theme

\begin{tabular}{c|l|l|l} 
& \multicolumn{1}{|c|}{ Prologue } & \multicolumn{1}{c|}{ Narration VI } & \multicolumn{1}{c}{ Narration VIII } \\
\hline Content & $\begin{array}{l}\text { Presentation of the } \\
\text { original theme and } \\
\text { Glorias including Alleluia }\end{array}$ & $\begin{array}{l}\text { Extension of the Glorias } \\
\text { including Alleluia in length, } \\
\text { dynamic, and key as well as } \\
\text { choral and orchestra forces. }\end{array}$ & $\begin{array}{l}\text { Diminution of the } \\
\text { Gloria theme } \\
\text { (the use of the } \\
\text { fragments of the theme) }\end{array}$ \\
\hline Length & 63 measures & 85 measures & 21 measures \\
\hline Key & G lydian & $\begin{array}{l}\text { (Bb Lydian) } \rightarrow \text { G lydian } \rightarrow \\
\text { (A lydian) } \rightarrow \text { G lydian }\end{array}$ & G lydian \\
\hline Dynamic & $\boldsymbol{f \rightarrow f f \rightarrow f f}$ & $\begin{array}{l}\text { Soprano soloist and mixed } \\
\text { choir }\end{array}$ & Women's choir \\
\hline
\end{tabular}

The Gloria theme is introduced in measures 57 to 119 in the first movement. The raised fourth of the theme indicates G lydian, "though the choral Glorias make many triadic side-steps." theme is associated with the text, 'Gloria in excelsis Deo' (Glory in the highest), and is repeated in entirety as well as in part several times throughout the movement.
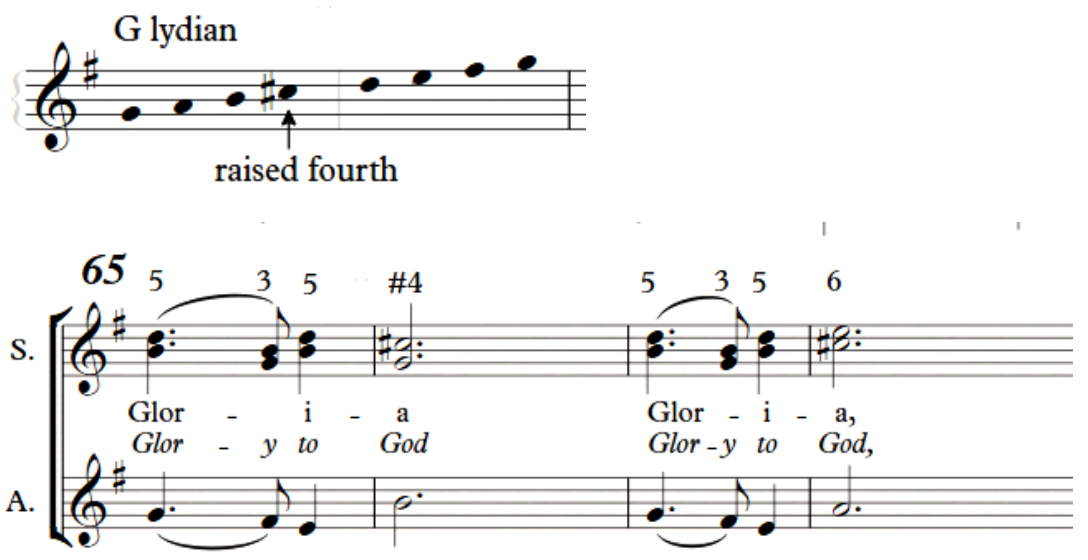

Figure 3-1 The G lydian scale and the Gloria theme in the soprano and alto entrance (m. 65-8) (C) Oxford University Press 1954. Extracts from vocal score reproduced by permission.

${ }^{8}$ Wilfrid Mellers. Vaughan Williams and the Vision of Albion. Illminster: Albion Music, 1997: 211. 
The Gloria theme initially appears in the orchestra from measures 56 to 64 , but the theme moves to the mixed choir at measure 65 . It has been observed that:

Vaughan Williams uses a fairly strict canonic treatment of descending 'Glorias' between the sopranos and tenors, and the altos and basses for the first few measures of this section... as if from the host of heaven 'Alleluia' answers the earth, marching upwards to meet the angels. ${ }^{9}$

The Gloria theme as it appears in the orchestra as well as in the mixed choir can be found in figure 3-2. The mixed choir repeats the orchestral theme, and follows with descending sequences of the Glorias.
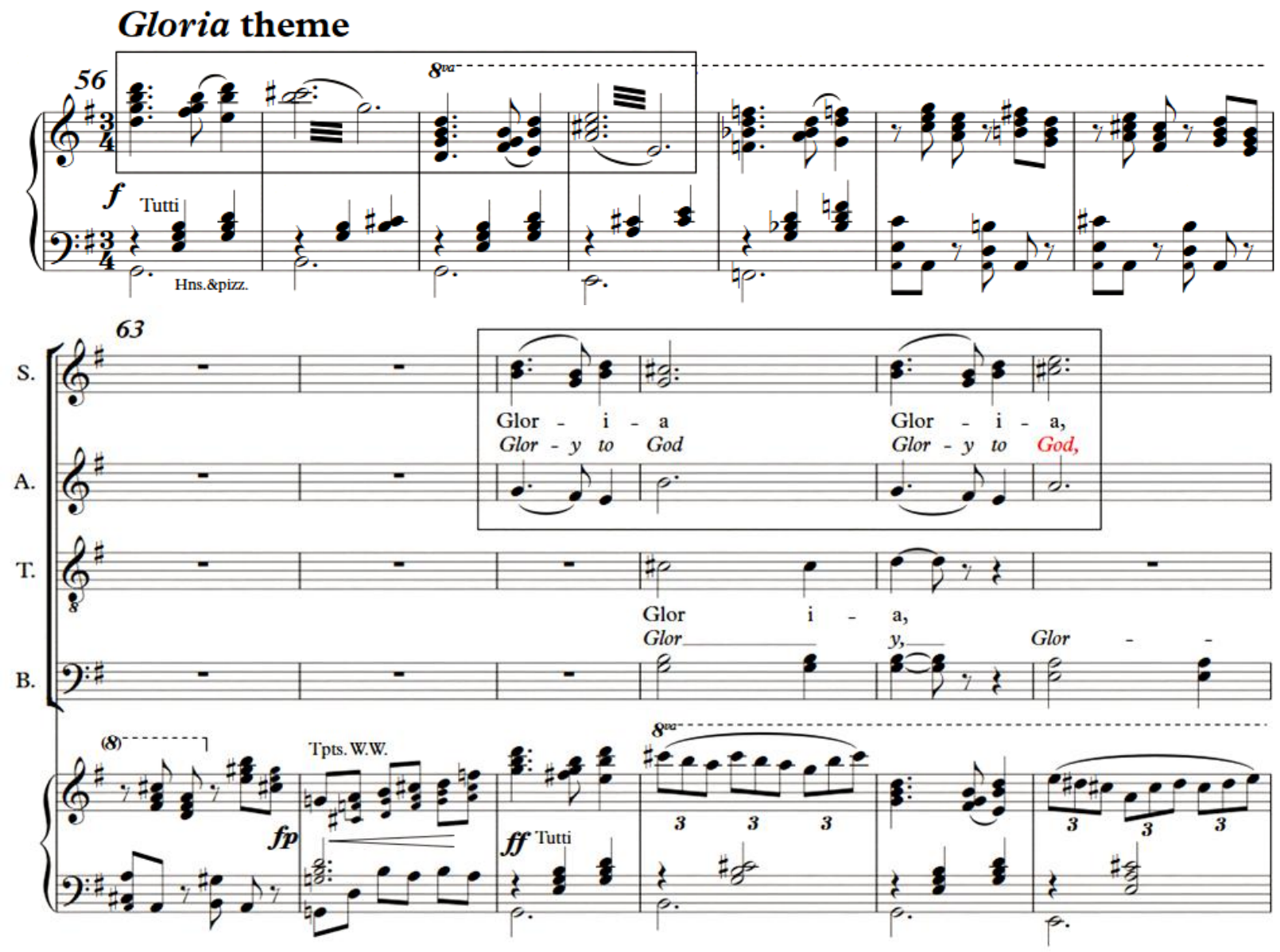

${ }^{9}$ Etter, 88. 


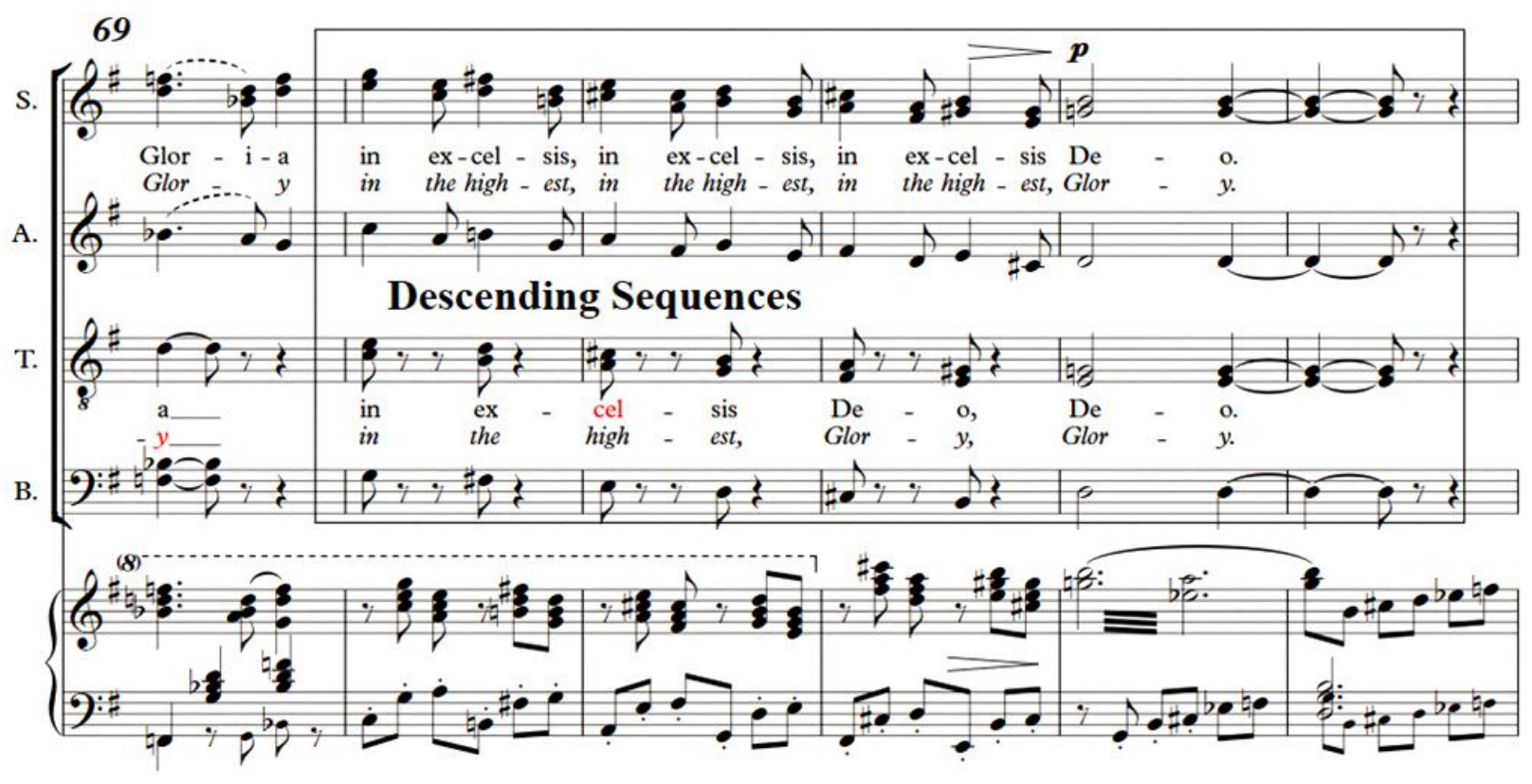

Figure 3-2 The Glorias in the orchestra and mixed choir (m. 56-74) (C) Oxford University Press 1954. Extracts from vocal score reproduced by permission.

The Gloria theme reappears in Narrations VI and VIII, but the theme in these movements differs from the original statement. In Narration VI, Vaughan Williams took several statements of the Glorias including Alleluia (m. 56-119) from the first movement. However, the section is extended in length, ${ }^{10}$ modified by key, and rearranged for the choir. Unlike the first movement, the Gloria theme alternates between the orchestra and the soprano solo. Dynamic changes ranging from piano $(P)$ to fortissimo $(f f)$ also appear.

${ }^{10}$ The part of the Gloria including Alleluia in the Narration VI lasts for 22 measures more in length than in the first movement. 

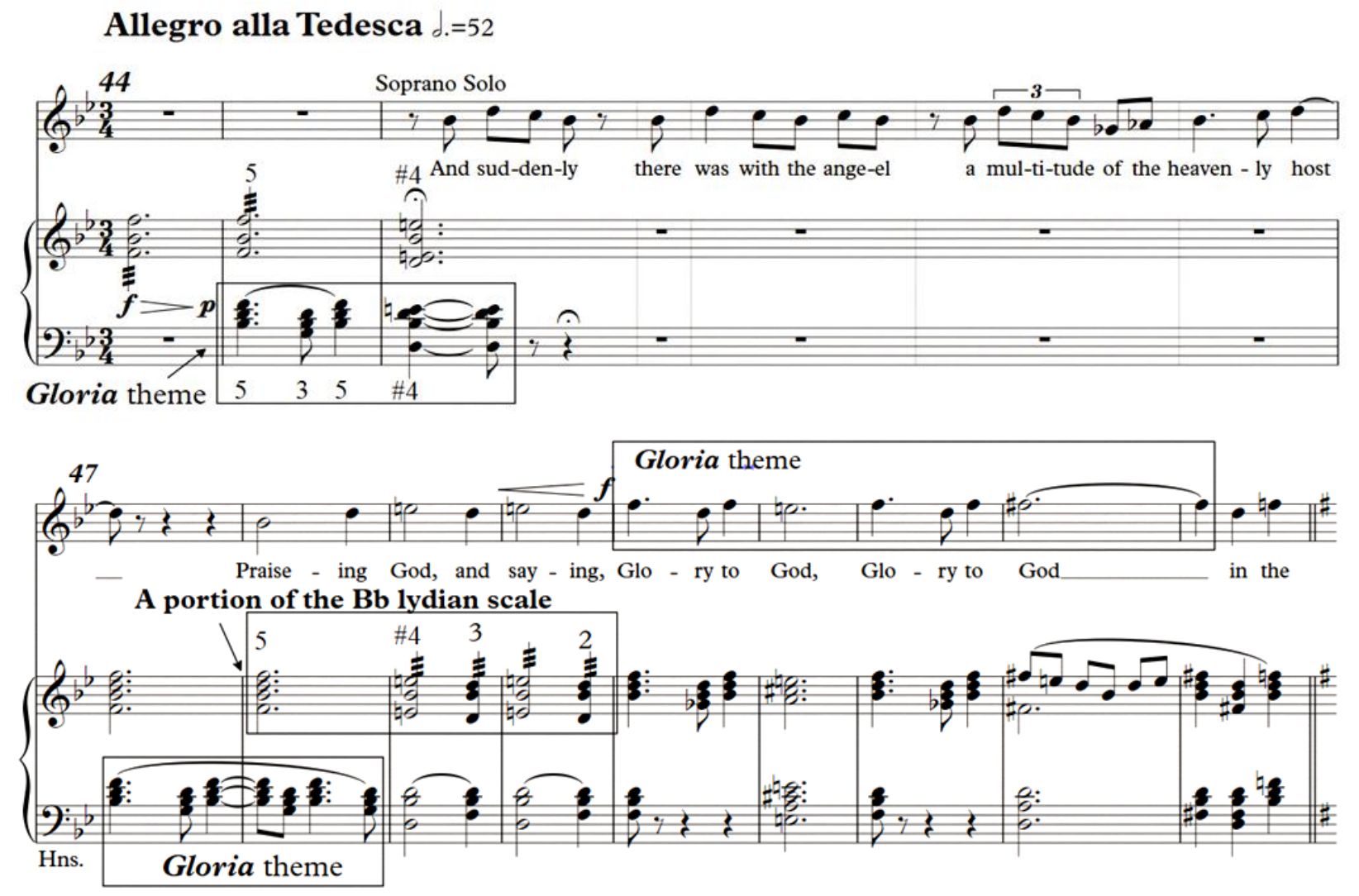

Figure 3-3 The Gloria theme in Narration VI (m. 44- 55)

(C) Oxford University Press 1954. Extracts from vocal score reproduced by permission.

The Gloria theme appears again in Narration VIII considerably shortened. The complete Gloria theme based in G lydian is presented in the middle of the movement and with the lowered $7^{\text {th }}$ note joined with G lydian at the end of the movement. The theme appeares in the women's choir and orchestra after the boy's choir and organ. Etter comments that the women's voices "decrescendo towards the end, the last traces we hear of the heavenly host, as if they are returning to heaven."11 After introducing the complete theme quietly, it gradually vanishes with descending small fragments.

\footnotetext{
${ }^{11}$ Etter, 117.
} 

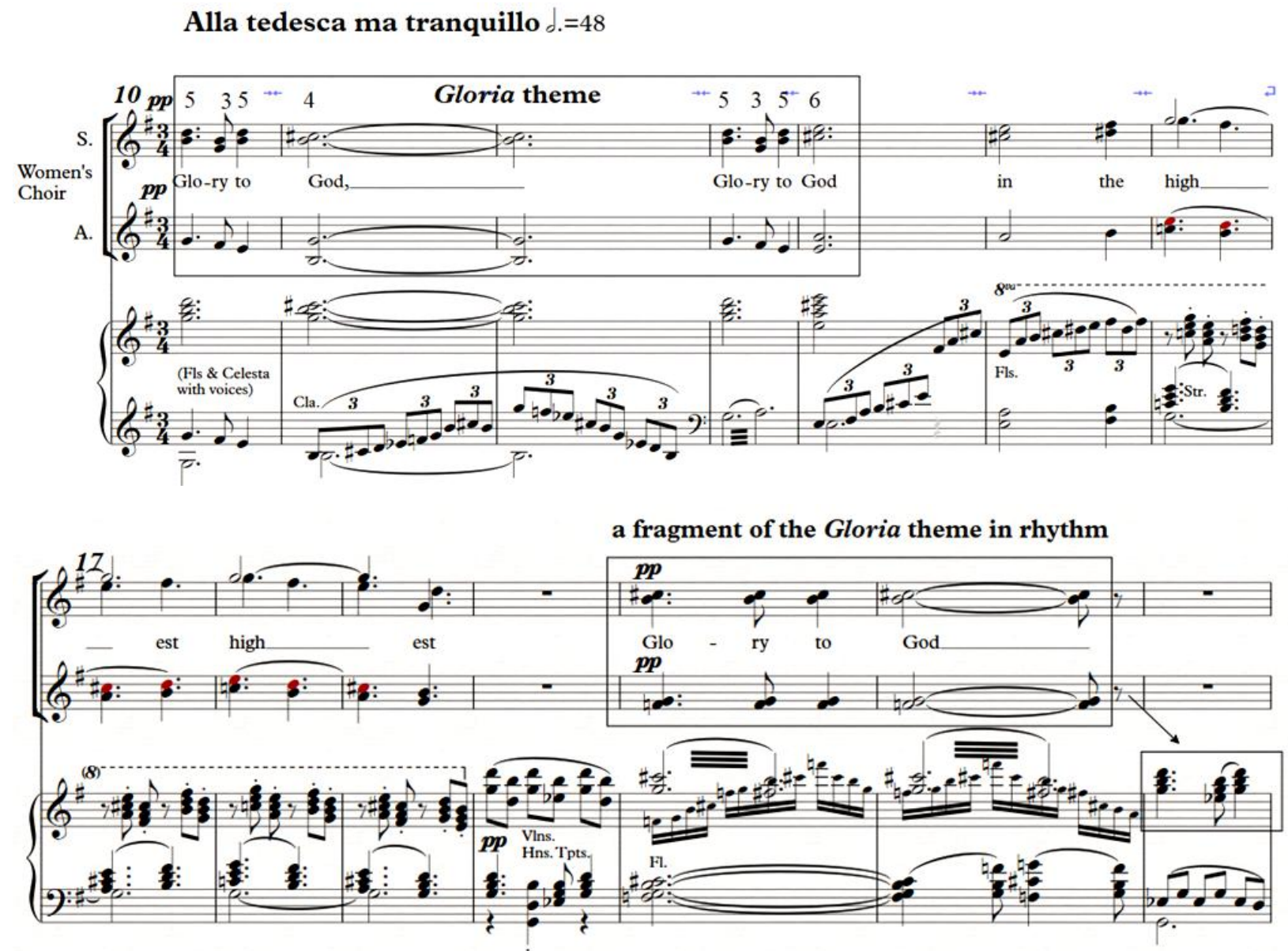

the fragments of the Gloria theme in rhythm

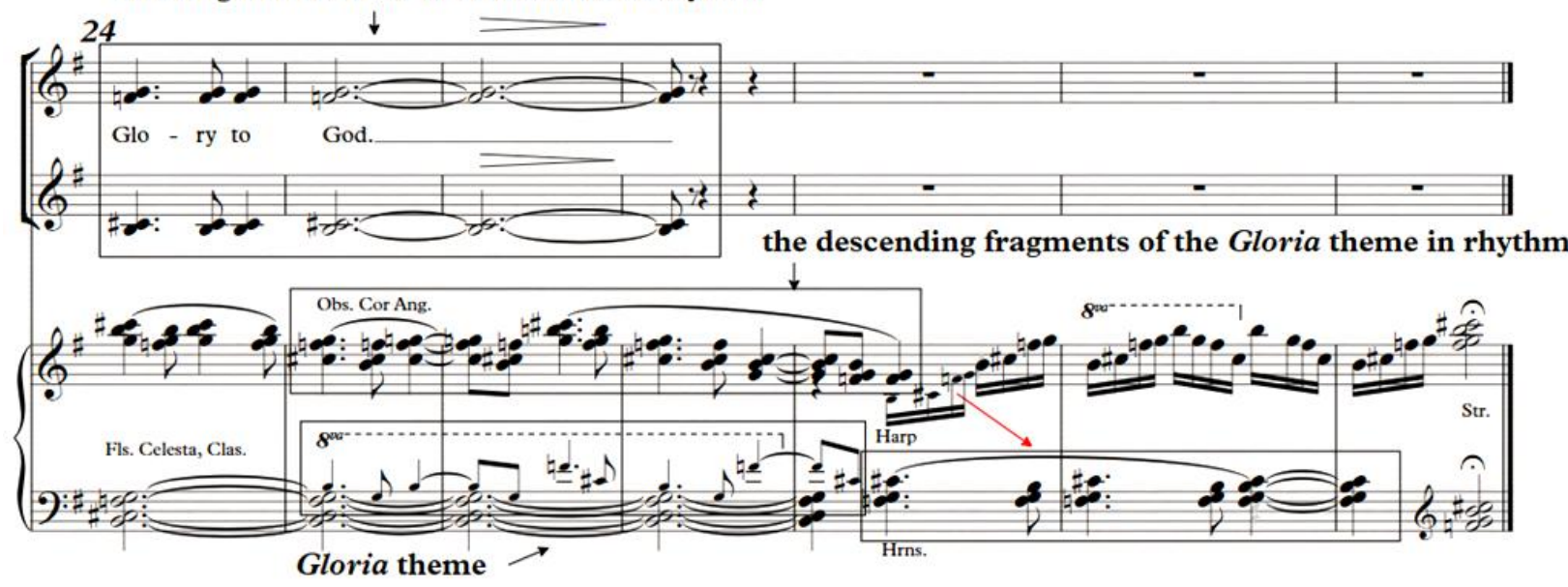

Figure 3-4 The Gloria theme in Narration VIII (m.10-30)

(C) Oxford University Press 1954. Extracts from vocal score reproduced by permission. 


\section{The Boy Evangelists Themes}

The boy's choir in Narrations acts as 'the angelic messenger telling the tale of Christ's miraculous birth,"12 based on the Gospels. The choir is placed at the beginning of the Narration, and scored in unison to convey "impersonality and neutrality." "I3 "It is these narrations, always presented modally, that link the poems together." ${ }^{\prime 14}$ There are three themes for the boy's choir, the boy evangelists theme 1, the boy evangelists theme 2 , and the boy evangelists theme 3 . Unlike the Gloria theme, these three themes vary depending on the text. Because they tell the story in narrative style, musical elements including melody, length, key, and harmony are frequently changed whenever the themes reappear in other Narrations, while keeping the basic thematic idea intact. The Boy evangelists theme 1 consists of triplets and pentatonic figurations based in a major key. It appears in Narrations II, IV, and X with different text, figurations, length, and key. The boy evangelists theme 2 occurs in Narrations IV, VI, and XIII. While it contains the triplets and pentatonic figurations of the boy evangelists theme 1, it also includes cross-relations between triads, several key changes, different text, figurations, and length. Unlike the previous two themes, descending and ascending thirds on pentatonic figurations are important musical elements in the boy evangelists theme 3. Appearing in Narrations VI, VIII, and XIII, the theme changes in length, key, choral forces as well as dynamics whenever it reappears with different text. Consequently, the compositional techniques become more complicated whenever the

\footnotetext{
12 Mellers, 211.

13 Mellers. 211.

${ }^{14}$ Etter, 92.
} 
themes repeat in other Narrations. Three tables below present a comparison of the changes in the original theme.

Table 3.3 The Boy Evangelists Theme 1

\begin{tabular}{l|l|l|l} 
Content of & \multicolumn{1}{|c|}{ Narration II } & \multicolumn{1}{c}{ Narration IV } & \multicolumn{1}{c}{ Narration X } \\
Text & $\begin{array}{l}\text { "The tale of Christ's } \\
\text { miraculous birth and the } \\
\text { visitation of the angelic } \\
\text { messenger"15 }\end{array}$ & $\begin{array}{l}\text { The visit to Bethlehem for } \\
\text { the gathering of taxes }\end{array}$ & $\begin{array}{l}\text { "Mary kept all these things, } \\
\text { and pondered them in her } \\
\text { heart" } \\
\text { Luke 2:19 }\end{array}$ \\
\hline Characteristics & $\begin{array}{l}\text { Triplets and pentatonic } \\
\text { figurations based on a } \\
\text { major scale }\end{array}$ & $\begin{array}{l}\text { The triplets and pentatonic } \\
\text { figurations, including } \\
\text { meter changes and } \\
\text { chromatic alternations }\end{array}$ & $\begin{array}{l}\text { A shortened theme, } \\
\text { containing pentatonic } \\
\text { figurations, triplets, } \\
\text { augmented triplets, and a } \\
\text { meter change }\end{array}$ \\
\hline Length & 26 measures & 20 measures & 8 measures \\
\hline Key & F major & F major & Gb major \\
\hline Dynamics & $P$ & $P$ & $P$
\end{tabular}

Table 3.4 The Boy Evangelists Theme 2

\begin{tabular}{|c|c|c|c|}
\hline & Narration IV & Narration VI & Narration XIII \\
\hline $\begin{array}{l}\text { Content of } \\
\text { Text }\end{array}$ & $\begin{array}{l}\text { The moment of the birth } \\
\text { of Jesus }\end{array}$ & $\begin{array}{l}\text { The angel visit to the } \\
\text { shepherds }\end{array}$ & The adoration of the Magi \\
\hline Characteristics & $\begin{array}{l}\text { The triplets and } \\
\text { pentatonic figurations } \\
\text { based on lydian mode, } \\
\text { embracing cross-relations } \\
\text { between triads of D } \\
\text { lydian and A aeolian } \\
\text { modes }\end{array}$ & $\begin{array}{l}\text { The triplets and } \\
\text { pentatonic figurations } \\
\text { based on D lydian mode } \\
\text { embracing cross-relations } \\
\text { between triads of D } \\
\text { lydian mode and F major }\end{array}$ & $\begin{array}{l}\text { The theme is based on } \\
\text { pentatonicism on E at the first } \\
\text { part, appearing in organ } \\
\text { accompaniment (m.1-9), and it } \\
\text { presents again in boy's choir } \\
\text { (m.21-55) with key changes } \\
\text { and orchestral accompaniment } \\
\text { consisting of flowing } 8^{\text {th }} \text { notes }\end{array}$ \\
\hline Length & 12 measures & 15 measures & $\begin{array}{l}9 \text { measures (the first part) }+ \\
35 \text { measures (the second part) }\end{array}$ \\
\hline Key & $\begin{array}{l}\text { D lydian and A aeolian } \\
\text { modes }\end{array}$ & $\begin{array}{l}\text { D lydian and A aeolian } \\
\text { modes }\end{array}$ & $\begin{array}{l}\mathrm{E} \text { aeolian (the first part) and } \mathrm{E} \\
\text { aeolian, E major, and } \mathrm{E} \\
\text { aeolian (the second part) }\end{array}$ \\
\hline Dynamics & $P$ & $P$ & $P$ \\
\hline
\end{tabular}

\footnotetext{
${ }^{15}$ Mellers, 211.
} 
Table 3.5 The Boy Evangelists Theme 3

\begin{tabular}{|c|c|c|c|}
\hline & Narration VI & Narration VIII & Narration XIII \\
\hline $\begin{array}{l}\text { Content of } \\
\text { Text }\end{array}$ & The visit of the shepherds & Glorifying and praising God & The visitation of the Magi \\
\hline Characteristics & $\begin{array}{l}\text { Descending and } \\
\text { ascending } 3^{\text {rd }} \text { intervals on } \\
\text { pentatonic figurations. } \\
\text { In boy's choir, the theme } \\
\text { is extended }\end{array}$ & $\begin{array}{l}\text { Descending and ascending } \\
3^{\text {rd }} \text { intervals on pentatonic } \\
\text { figurations. } \\
\text { Quarter notes pizzicato bass } \\
\text { in organ move continually } \\
\text { on F }\end{array}$ & $\begin{array}{l}\text { Descending and ascending } \\
3^{\text {rd }} \text { intervals on pentatonic } \\
\text { figurations. } \\
\text { Several short key changes. } \\
\text { Men's and women's choirs } \\
\text { are inserted between boy's } \\
\text { choirs }\end{array}$ \\
\hline Length & $\begin{array}{l}7 \text { measures (men's choir) } \\
+18 \text { measures (boy's } \\
\text { choir) }\end{array}$ & 9 measures & 17 measures (m.4-20) \\
\hline Key & $\begin{array}{l}\text { G major, with touches of } \\
\text { E Aeolian mode }\end{array}$ & $\mathrm{Ab}$ and $\mathrm{G}$ majors & $\begin{array}{l}\text { G major (boy's choir), G } \\
\text { aeolian (men's choir), B } \\
\text { aeoian (boy's choir), and C } \\
\text { aeolian (women's choir) }\end{array}$ \\
\hline Choral forces & Men's and boy's choirs & Boy's choir & $\begin{array}{l}\text { Boy's, men's, and } \\
\text { women's choirs }\end{array}$ \\
\hline Dynamics & $\begin{array}{l}m f \text { (men's choir) } \\
p \text { (boy's choir) }\end{array}$ & $P \rightarrow P P$ & $\begin{array}{l}P(\text { boy's choir }) \rightarrow m f \\
(\text { men's choir }) \rightarrow \\
P P(\text { women's choir })\end{array}$ \\
\hline
\end{tabular}

\section{1) The Boy Evangelists Theme 1}

The boy evangelists theme 1 is introduced in Narration II (m.1-26). The theme is divided into two fragments, triplets in the organ and pentatonic figurations based on a major scale in the boy's choir. The fragments appear alternately in the organ and boy's choir. The Narration tells "the tale of Christ's miraculous birth and the visitation of the angelic messenger." ${ }^{\text {"16 }}$ Mellers explains that:

\footnotetext{
${ }^{16}$ Mellers, 211.
} 
It begins with a pentatonic melisma, but then supports the vocal declamation with simple concords freely related...Basically, the pentatonic declamation echoes that of the spoken words, with a minimum of expressivity let alone drama. The boys merely tell the tale; only occasionally does an unexpected (but still concordant) triad point a detail of the text, as when the 'angel of the Lord appeared unto him in a dream.' 17

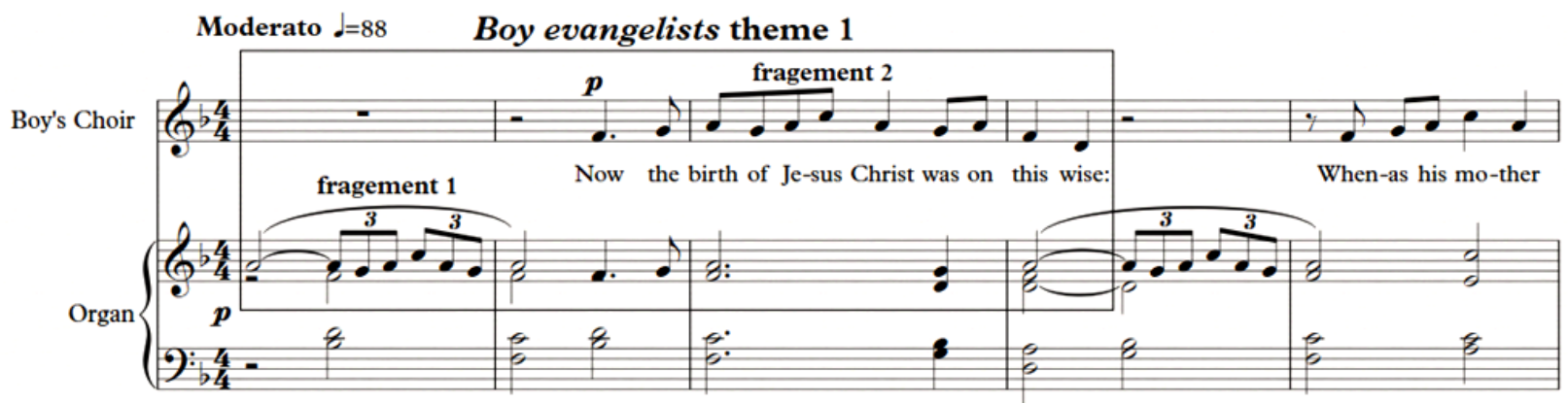

Figure 3-5 The boy evangelists theme 1 in Narration II (m. 1-5)

(C) Oxford University Press 1954. Extracts from vocal score reproduced by permission.

The boy evangelists theme 1 reappears in Narrations IV, VI, and X with slight changes in melody, length, key, and harmony corresponding to the changes in text. Narration IV recounts "the visit to Bethlehem for the gathering of taxes."18 Mellers observes that:

The music, recalling a distant past, is initially unchanged, though the minute chromatic alterations are, given the events recounted, more acute: consider the sudden A flat within the radiant F major, and the shift therefrom to lydian F sharp for the Child's birth. ${ }^{19}$

Narration IV is divided in two parts. The first part (m.1-20) shown in figure 3-6 includes changes in key and melody.

\footnotetext{
${ }^{17}$ Mellers, 211.

${ }^{18}$ Mellers, 212.

${ }^{19}$ Mellers, 212.
} 

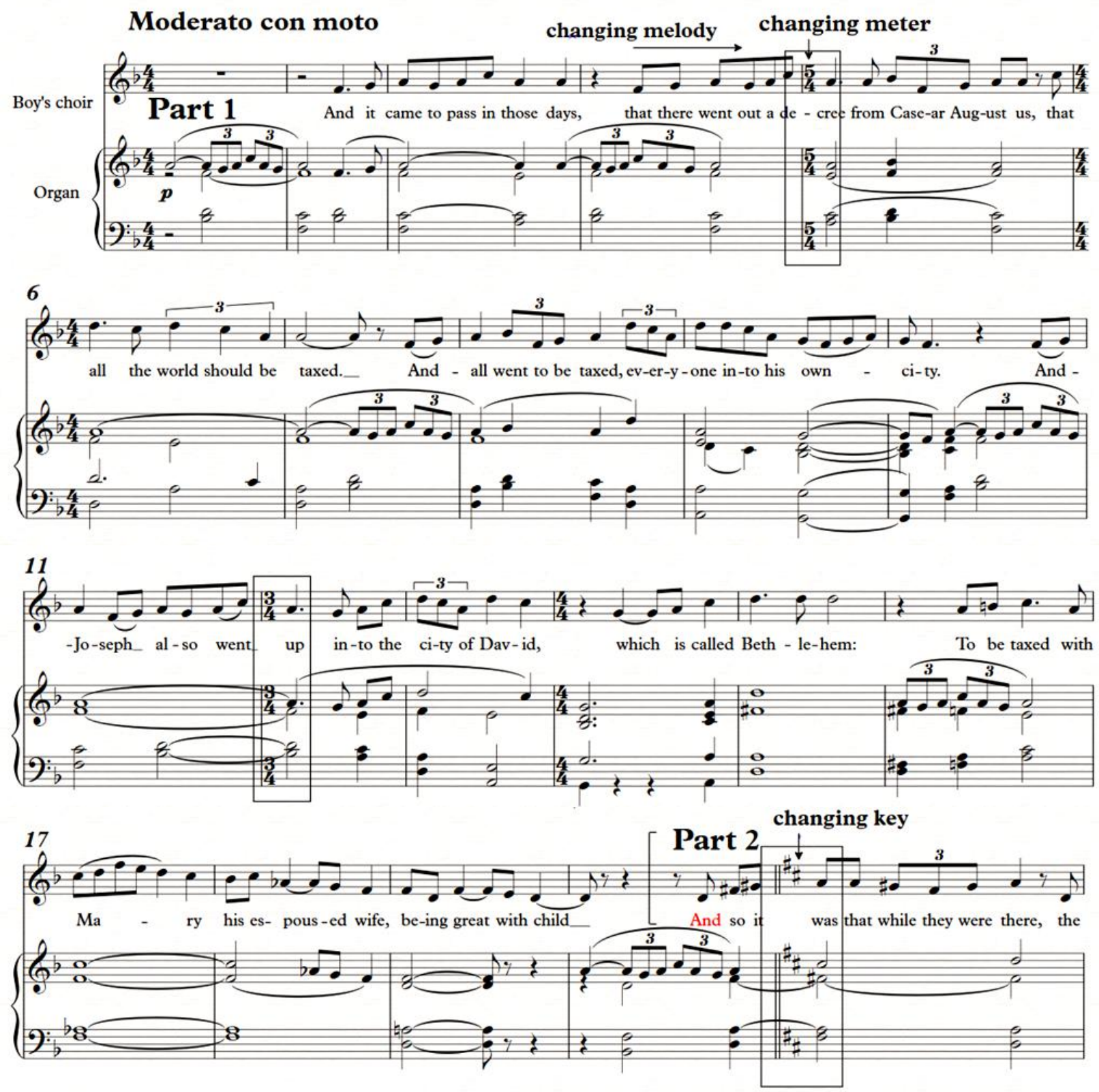

Figure 3-6 The boy evangelists theme 1 in Narration IV (m.1-21)

(C) Oxford University Press 1954. Extracts from vocal score reproduced by permission.

The boy evangelists theme 1 comes back in Narration X. Unlike its appearance in Narrations II and IV, it is extremely shortened to 8 measures. This short Narration is inserted like a brief interlude between two poetic insertions, Pastoral and Lullaby. Mellers comments that "only a very brief narration separates this song, [Pastoral,] from the hardly less exquisite Lullaby,...The 
Narration is in G flat - really F sharp as upper median to the Pastoral's D. ${ }^{20}$ Changes in meter, harmony and key as well as augmented triplets occur as shown in figure 3-7.

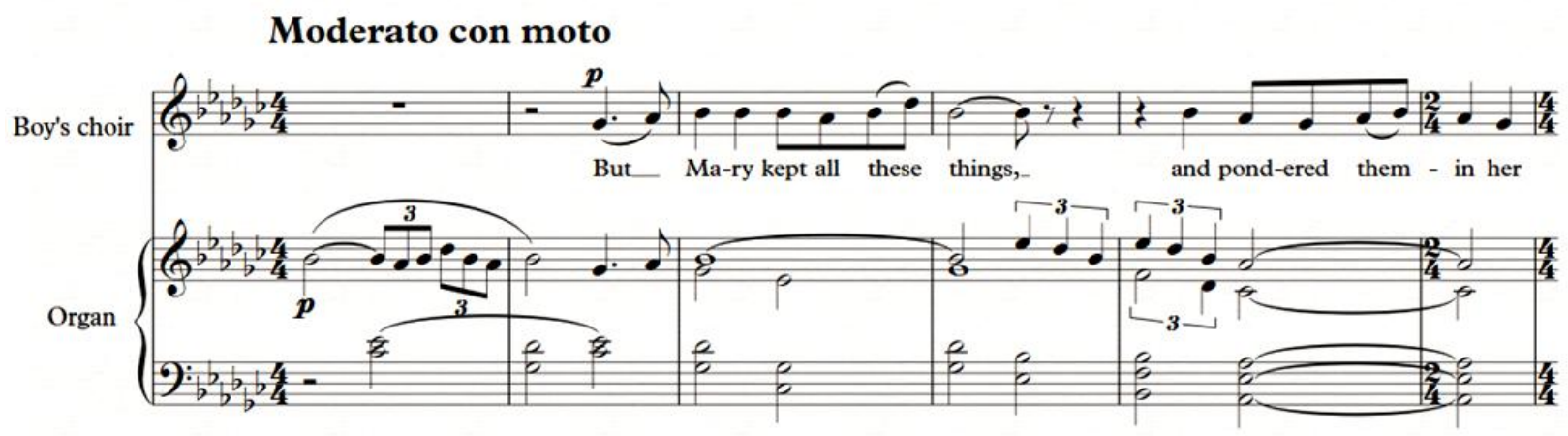

Figure 3-7 The boy evangelists theme 1 in Narration X (m.1-6)

(C) Oxford University Press 1954. Extracts from vocal score reproduced by permission.

\section{2) The Boy Evangelists Theme 2}

The boy evangelists theme 2 appears in the second part of Narration IV (m. 21-32), and recounts the moment of the birth of Jesus. The theme contains the triplets and pentatonic figurations of the boy evangelists theme 1, but is in lydian mode embracing cross-relations between triads of D lydian and $\mathrm{A}$ aeolian modes. It also moves more freely than the boy evangelists theme 1 .

\footnotetext{
${ }^{20}$ Mellers, 215.
} 

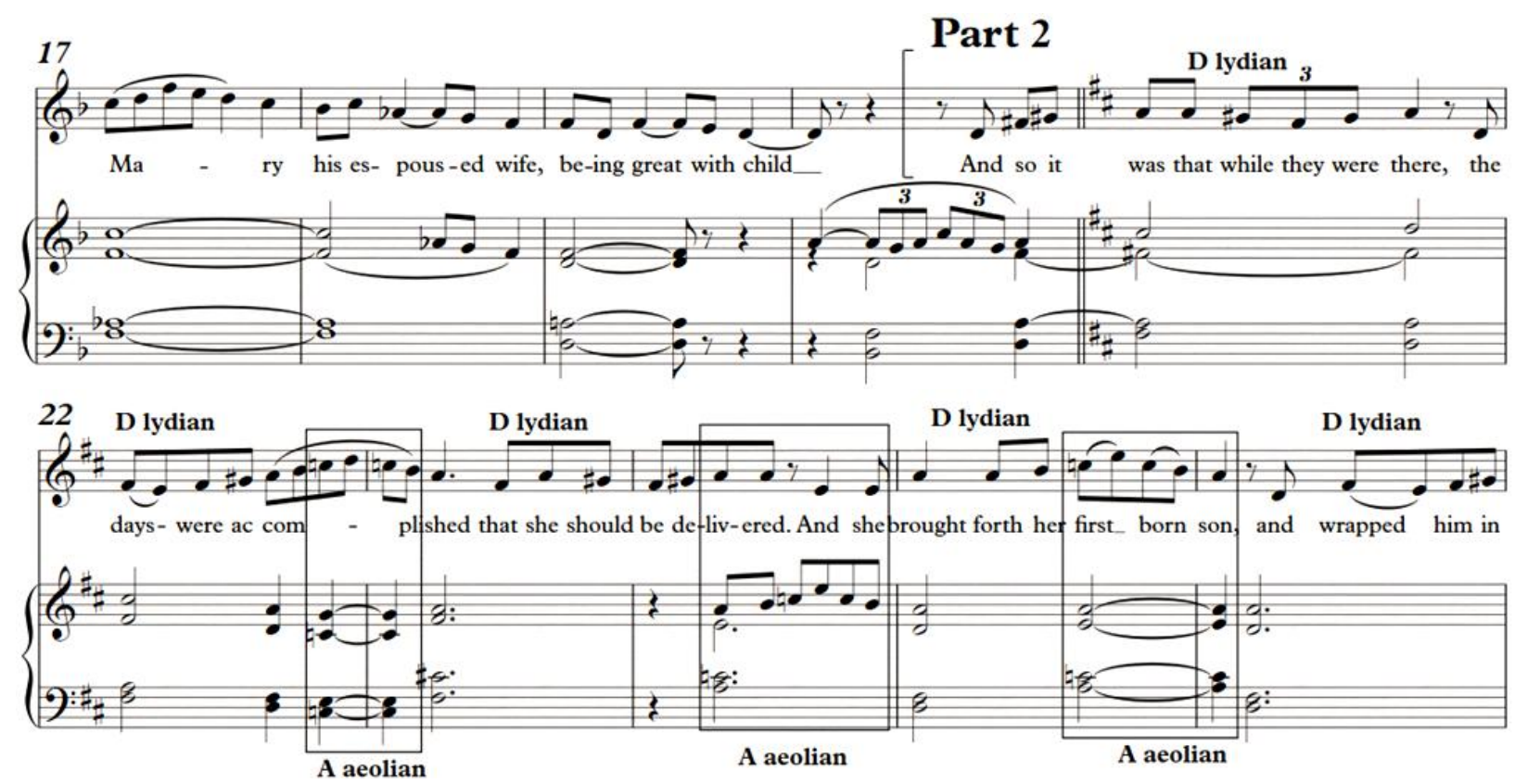

Figure 3-8 The boy evangelists theme 2 in Narration IV (m.17-26)

(C) Oxford University Press 1954. Extracts from vocal score reproduced by permission.

Narration VI begins with the boy evangelists theme 2. But here it is shortened to 15 measures, and relates to the angel visit to the shepherds. The theme appears in D lydian mode embracing cross-relations between triads of D lydian mode and F major (m.1-6), followed by the mode change to A aeolian mode at $\mathrm{m}$. 6 with a B minor chord inserted between the two tonic chords of A aeolian mode at measure 8, as shown in figure 3-9. 

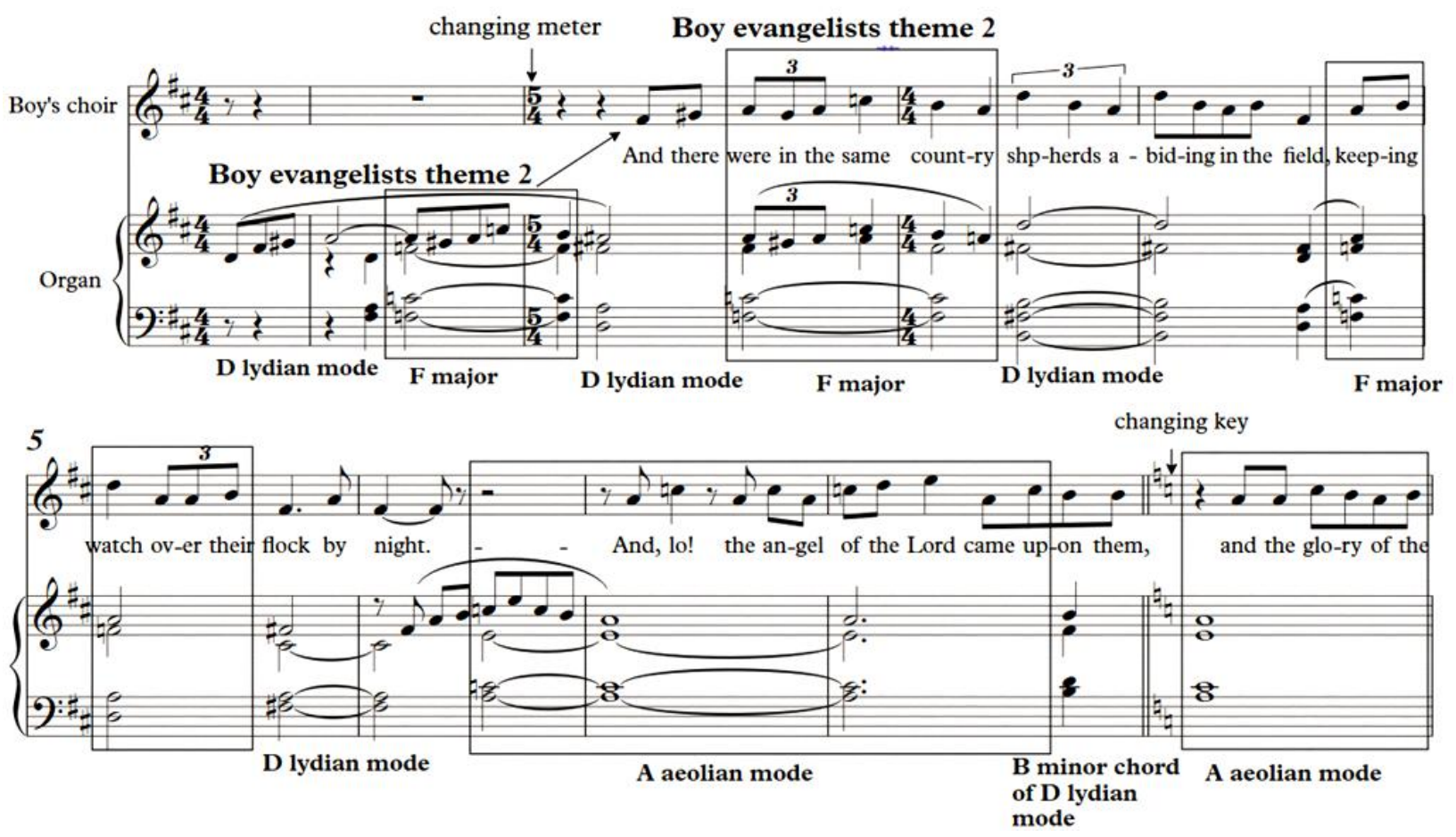

Figure 3-9 The boy evangelists theme 2 in Narration VI (m.1-9)

(C) Oxford University Press 1954. Extracts from vocal score reproduced by permission.

The boy evangelists theme 2 appears at the beginning of the Narration XIII (m.1-20) where "brief interpolations... in G aeolian [are given to the] men's section, when speaking for the Kings [and to the women in C aeolian when] representing King Herod's wise men." ${ }^{21}$ The men's and women's sections are inserted between the boy's sections. While, in the second part (m.2055), the theme with several changes in mode appears only in the boy's choir, Etter comments that "a shining moment occurs when the trebles alter the key to E major when briefly singing of the rejoicing of the star, only to return to E aeolian to end of movement." ${ }^{22}$ Mellers also observes that:

\footnotetext{
${ }^{21}$ Etter, 118.

${ }^{22}$ Etter, 118.
} 
The trebles' narration begins in unsullied pentatonicism on E, at first monodically, then in organum. At the appearance of the star over the manger tonality momentarily becomes an equally unsullied E major. ${ }^{23}$

As shown in figure 3-10, the boy evangelists theme 2 is introduced in the organ accompaniment at the beginning of the first part (m.1-10), but the theme appears in earnest in the second part with mode changes (m.20-55), where it tells of the adoration of the Magi. Based on pentatonicism, the theme reappears in boy's choir again (m.21-55) with key changes and orchestral accompaniment consisting of flowing eighth notes. While the boy evangelists theme 3 mostly occurs in choirs of the first part (m.10-20), there are several key changes. At the beginning, it appears in G major in the boy's choir accompanied by the organ in E aeolian mode. After that, the key changes shortly to G aeolian for the men's choir, B aeolian for the boy's choir, and $\mathrm{C}$ aeolian for the women's choir.

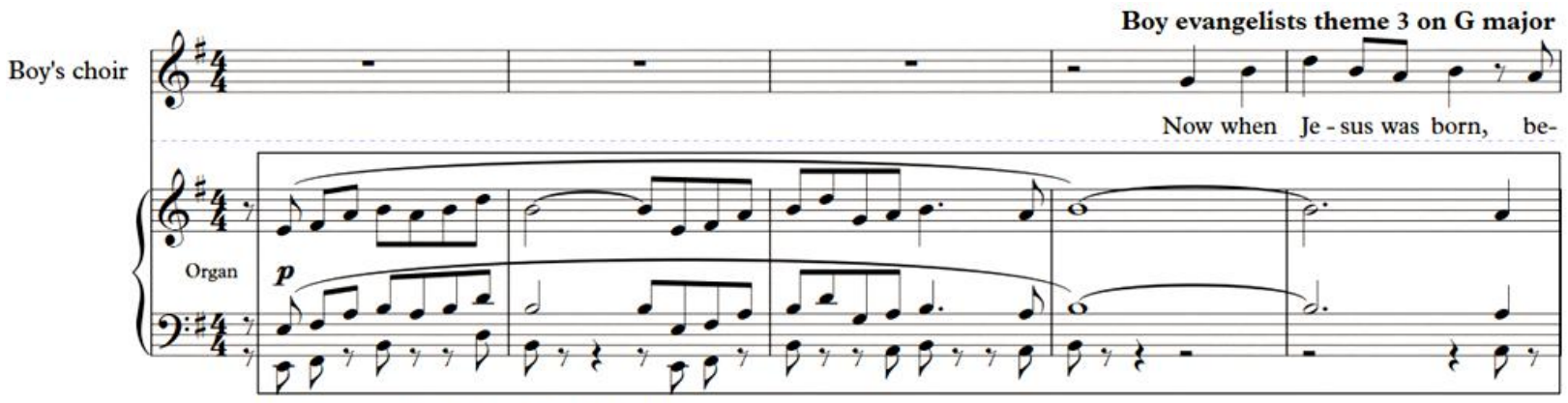

Boy evangelists theme 2 on $\mathrm{E}$ aeolian

\footnotetext{
${ }^{23}$ Mellers, 216
} 

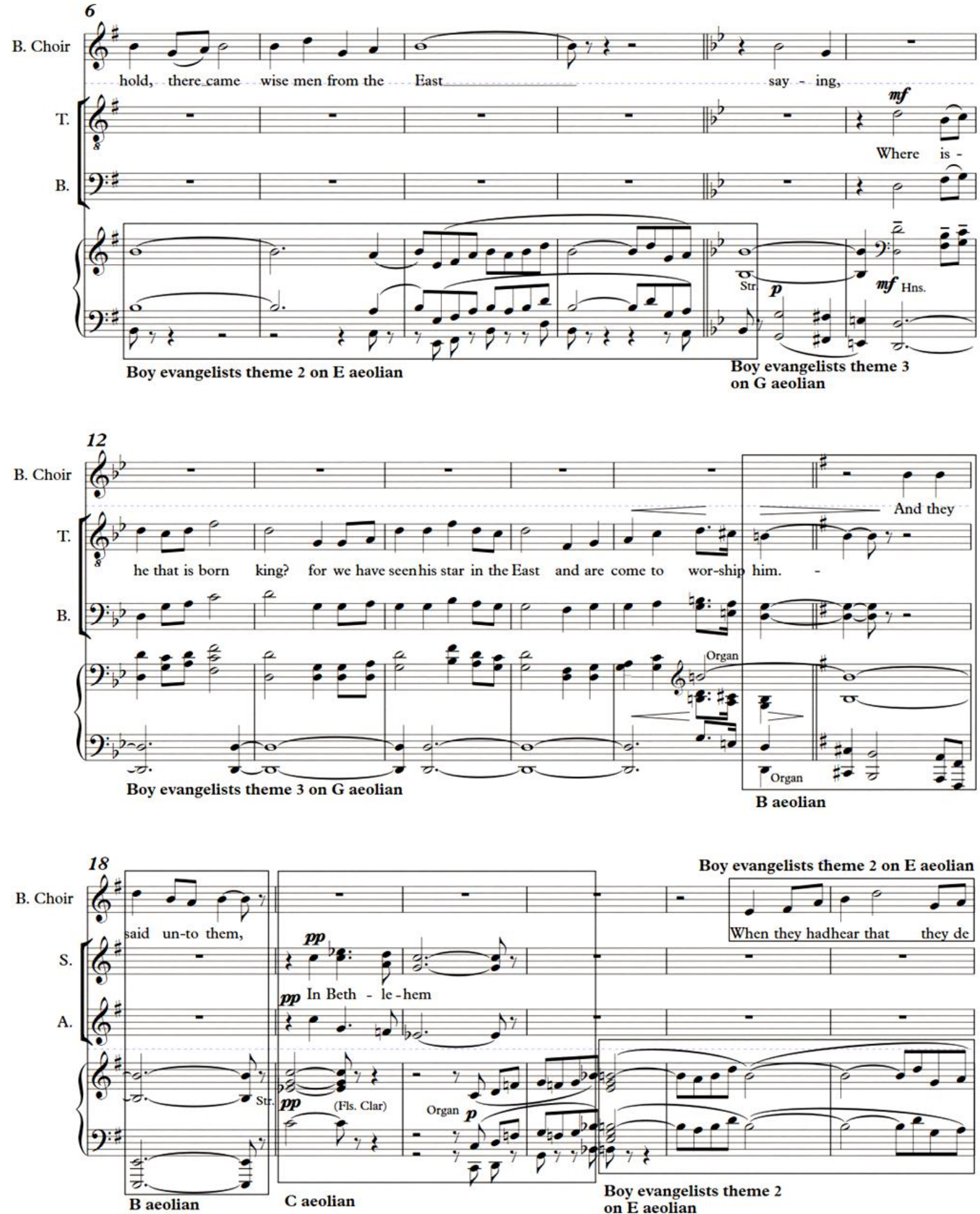

Figure 3-10 The boy evangelists theme 2 and the boy evangelists theme 3 in Narration XIII (m.123) (C) Oxford University Press 1954. Extracts from vocal score reproduced by permission. 


\section{3) The Boy Evangelists Theme 3}

The boy evangelists theme 3 initially appears in the men's choir at the end of the Narration VI (m.129-135), and it is repeated and extended in the boy's choir, (m.135-152). The theme tells of the visit of the shepherds to the Bethlehem. Unlike other boy evangelists themes, descending and ascending melodic thirds on pentatonic figurations are an important thematic element. As appears in figure 3-11, the theme is introduced in the men's choir with the boy's choir responding.
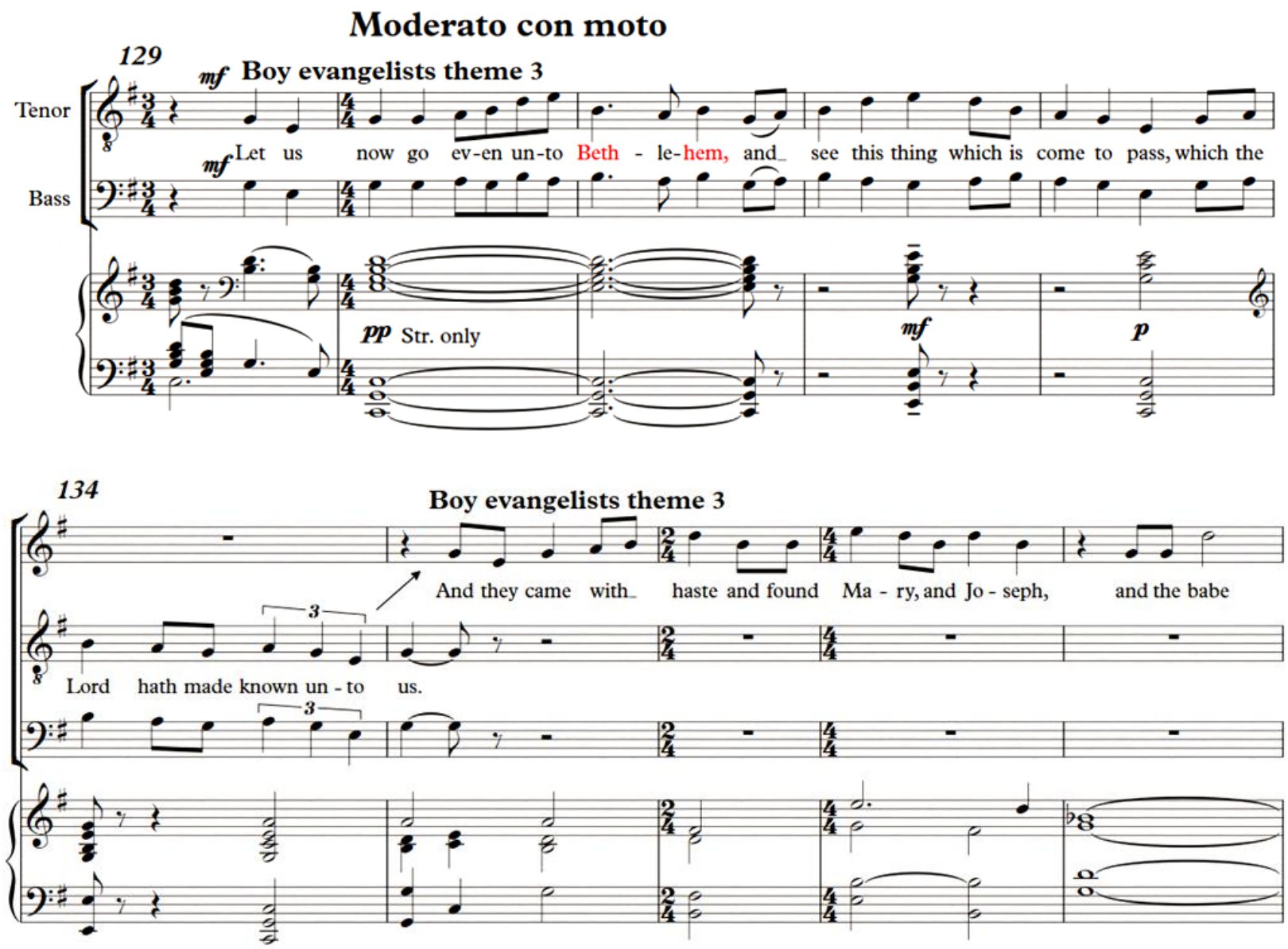

Figure 3-11 The boy evangelists theme 3 in Narration VI (m.129-138)

(C) Oxford University Press 1954. Extracts from vocal score reproduced by permission. 
The boy evangelists theme 3 reappears at the beginning of Narration VIII where it has been shortened (m.1-9), and modulates from $\mathrm{Ab}$ to $\mathrm{G}$ with the quarter notes pizzicato bass of the organ in F. The theme tells of the 'glorifying and praising God' as the shepherds return.
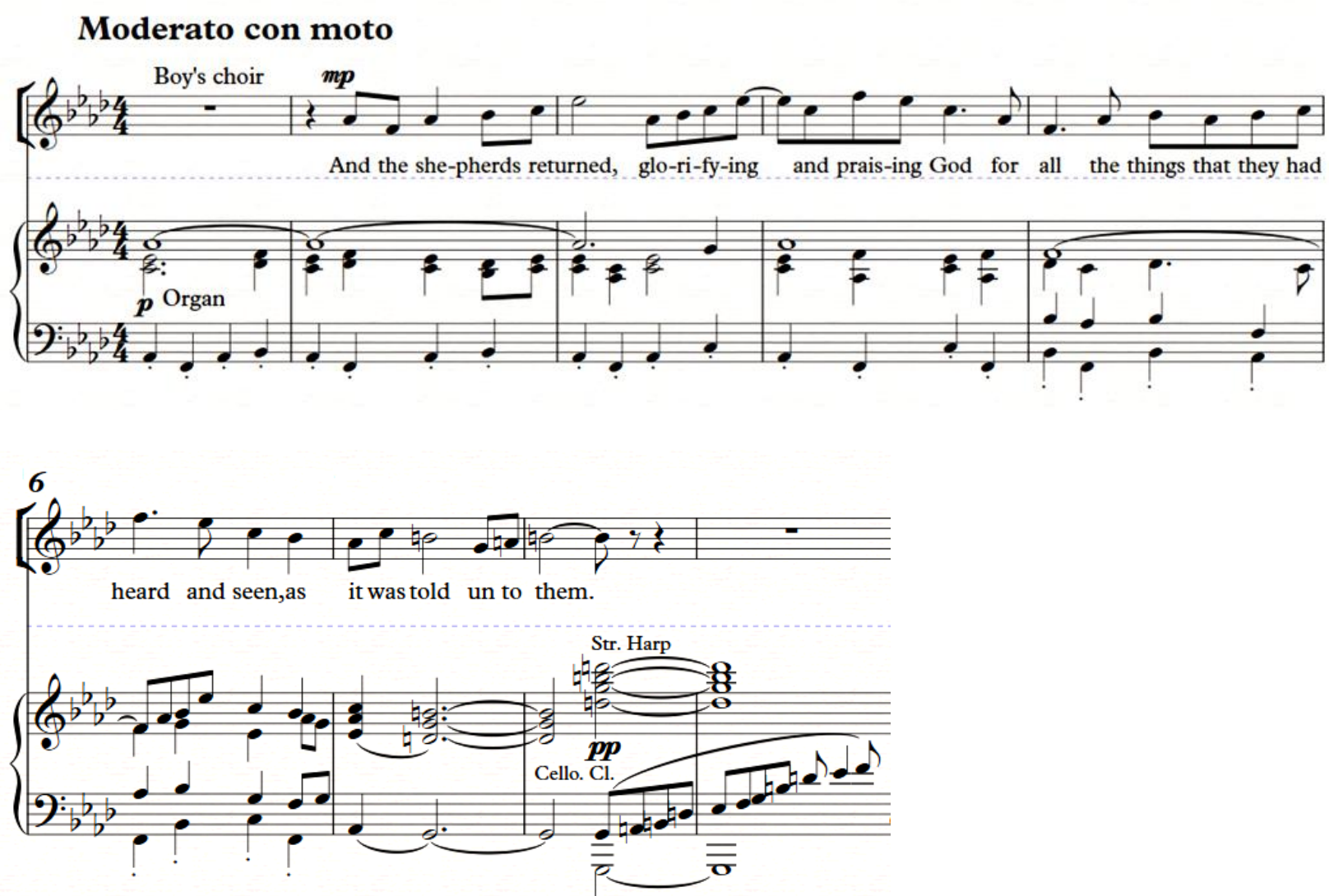

Figure 3-12 The boy evangelists theme 3 in Narration VIII (m.1-9)

(C) Oxford University Press 1954. Extracts from vocal score reproduced by permission

\section{The Blessing-Curse Theme}

The blessing-curse theme consists of one eighth rest followed by six pitches (G, F\#, E, D, $\mathrm{Eb}$, and $\mathrm{C})$. This short pattern does not change. Unlike the boy evangelists themes, the blessingcurse theme is not connected with a particular text. It is just repeated in the original or in an extended form regardless of text, and is mostly in C lydian mode, although the theme appears in $\mathrm{G}$ aeolian in the fourteenth movement. 


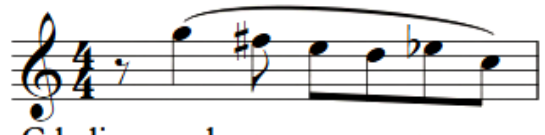

C lydian mode

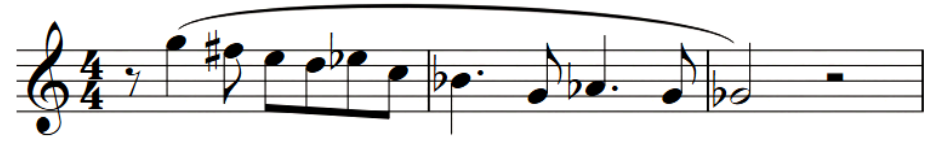

Figure 3-13 The blessing-curse theme and the extended blessing-curse theme (C) Oxford University Press 1954. Extracts from vocal score reproduced by permission

The blessing-curse theme appears in Narrations II and VI, as well as in two of the poetic insertions, 'The March of the Three Kings' and the 'Epilogue.' It is repeated several times with the almost the same form in Narrations II, VI, and the 'Epilogue, but because of the change in mode, a new figuration based on the original form is constructed for 'The March of the Three Kings,' as is indicated in table 3.6 which follows.

Table 3.6 The Blessing-Curse Theme

\begin{tabular}{l|l|l|l|l} 
& \multicolumn{1}{|c|}{ Narration II } & Narration VI & $\begin{array}{l}\text { The March of the } \\
\text { Three Kings }\end{array}$ & \multicolumn{1}{|c|}{ Epilogue } \\
\hline Content & $\begin{array}{l}\text { The original and } \\
\text { extended forms } \\
\text { based on cross- } \\
\text { relations between } \\
\text { triads of C major } \\
\text { and Eb minor. }\end{array}$ & $\begin{array}{l}\text { The original and } \\
\text { extended forms } \\
\text { based on cross- } \\
\text { relations between } \\
\text { triads of C major and } \\
\text { Eb minor. }\end{array}$ & $\begin{array}{l}\text { New figuration } \\
\text { based on original } \\
\text { theme. }\end{array}$ & $\begin{array}{l}\text { Adding new notes } \\
\text { and triplets in the } \\
\text { theme. }\end{array}$ \\
\hline Key (Mode) & C lydian & $\begin{array}{l}\text { C lydian } \\
\rightarrow \text { Bb lydian }\end{array}$ & $\begin{array}{l}\text { G aeolian } \\
\rightarrow \text { D aeolian } \\
\rightarrow \text { G aeolian }\end{array}$ & $\begin{array}{l}\text { Ab Lydian } \rightarrow \\
\text { C lydian }\end{array}$ \\
\hline Length & $\begin{array}{l}\text { m.27-29, } \\
\text { m.52-69. }\end{array}$ & $\begin{array}{l}\text { m.15-24, } \\
\text { m.34-43. }\end{array}$ & $\begin{array}{l}\text { m.70-72, } \\
\text { m.149-157. }\end{array}$ & $\begin{array}{l}\text { m.10-27, } \\
\text { m.32-35. }\end{array}$ \\
\hline $\begin{array}{l}\text { Orchestral/ } \\
\text { choral forces }\end{array}$ & $\begin{array}{l}\text { Tenor solo } \\
\text { and orchestra. }\end{array}$ & $\begin{array}{l}\text { Tenor solo } \\
\text { and orchestra. }\end{array}$ & $\begin{array}{l}\text { Orchestra } \\
\text { and mixed choir }\end{array}$ & $\begin{array}{l}\text { Orchestra } \\
\text { and tenor solo }\end{array}$
\end{tabular}

In Narration II, the blessing-curse theme occurs in the organ, tenor solo, and orchestra at the beginning of the second part (m.27-69). The original and extended forms are repeated several times in the movement. Mellers observes that: 
Certainly the angelic music itself is Schützian, for the heavenly visitor is characterized in music for tenor solo far more impassioned than the treble narrative. Indeed, his song turns out to be another permutation of the blessing-curse motif that plays so crucial a part in Job and the later symphonies. His descending cry is harmonized with false-related concords of light $\mathrm{C}$ major and dark E flat - a dichotomy that will haunt the rest of the cantata. ${ }^{24}$

Figure 3-14 presents the repeating blessing-curse theme as it appears in the organ and tenor solo.

The theme repeats two times in the organ, followed by an extension of the theme in the tenor solo and the organ.
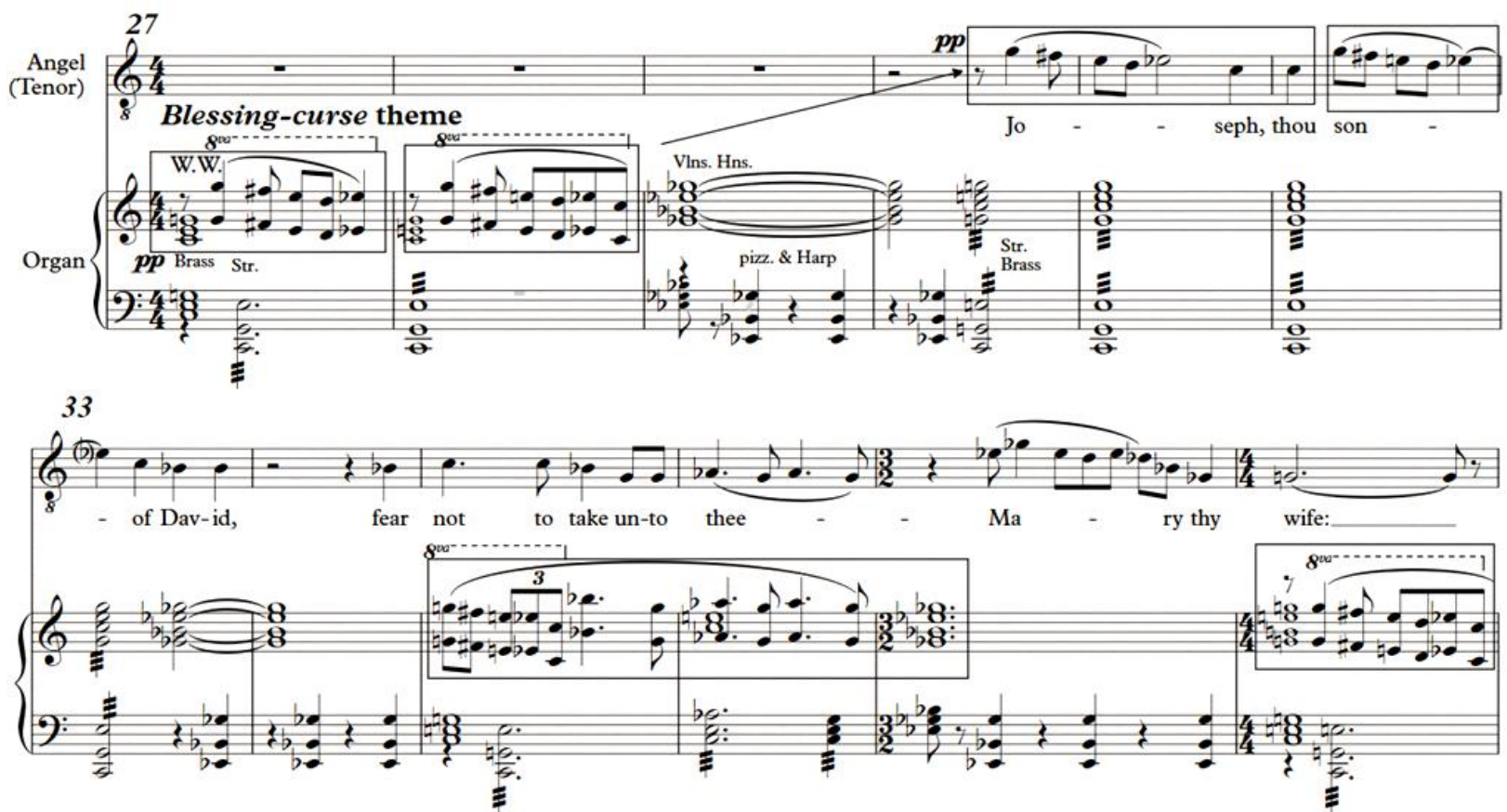

Figure 3-14 The blessing-curse theme in Narration II (m.27-38)

(C) Oxford University Press 1954. Extracts from vocal score reproduced by permission.

In Narration VI, the blessing-curse theme also appears in the tenor solo and orchestra. As in Narration II, the original and extended forms are used, but the extended theme is longer in this movement. Mellers comments that:

\footnotetext{
${ }^{24}$ Mellers, 211.
} 
The Angel, bringing good tidings, chants the blessing-curse theme sung at his first appearance, with the same harmonies alternating between light $\mathrm{C}$ major and dark $\mathrm{E}$ flat minor. But his melismata are more ecstatically extended,..${ }^{25}$

Also, the theme changes key from $\mathrm{C}$ lydian to $\mathrm{Bb}$ lydian as shown in figure 3-15.
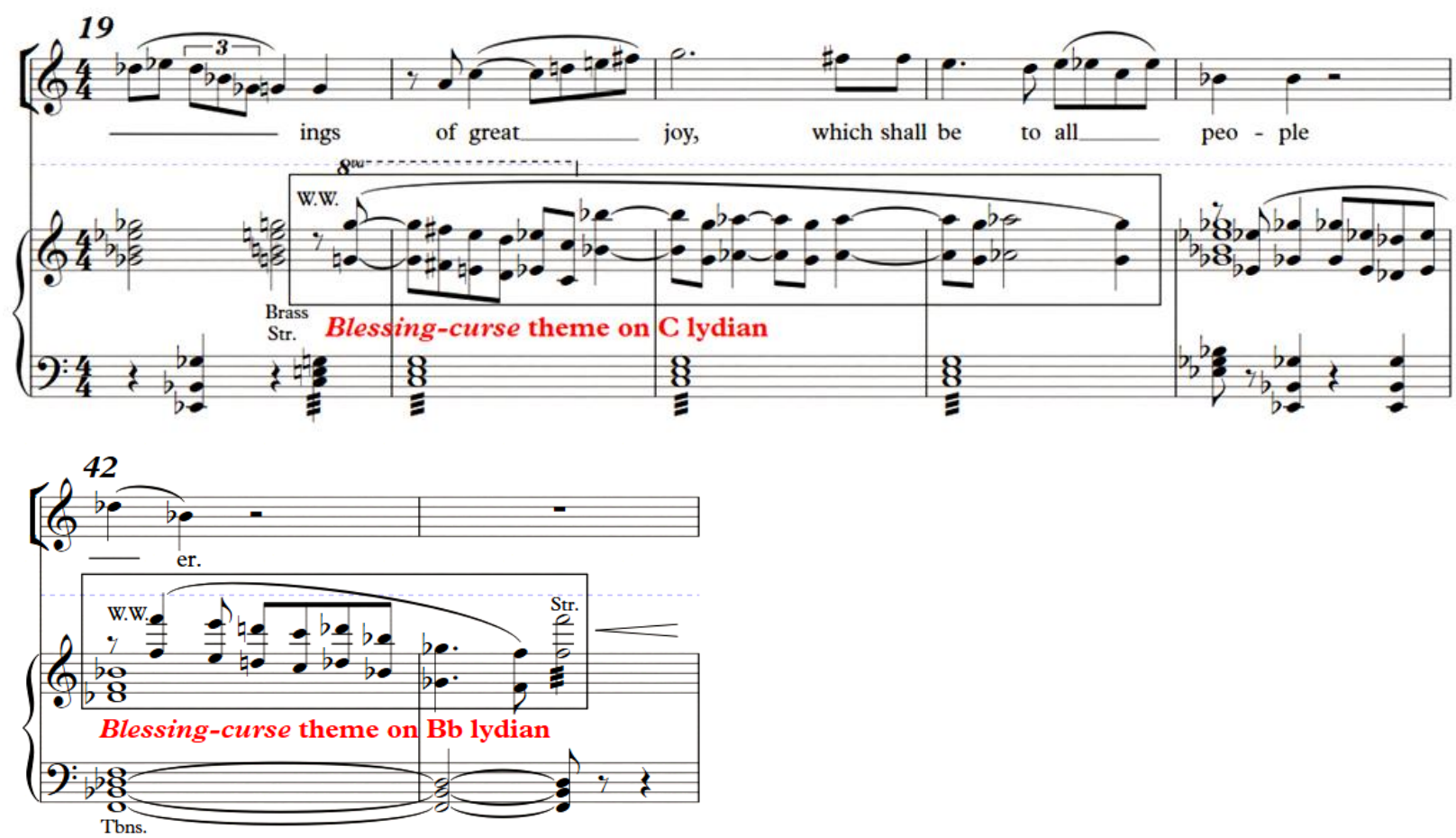

Figure 3-15 The blessing-curse theme in Narration VI (m.19-23) and (m.42-43)

(C) Oxford University Press 1954. Extracts from vocal score reproduced by permission.

In 'The March of The Three Kings,' the melodic figuration of the blessing-curse is changed due to the mode change. While the theme consisting of ten notes (G, F, E, F, G, D, C, D, C, and Bb) is usually found in $\mathrm{G}$ aeolian mode througthout the movement, it is modified to D aeolian in the middle of the movement as shown in figure 3-16.

\footnotetext{
${ }^{25}$ Mellers, 213.
} 
Blessing-curse theme on $\mathbf{G}$ aeolian

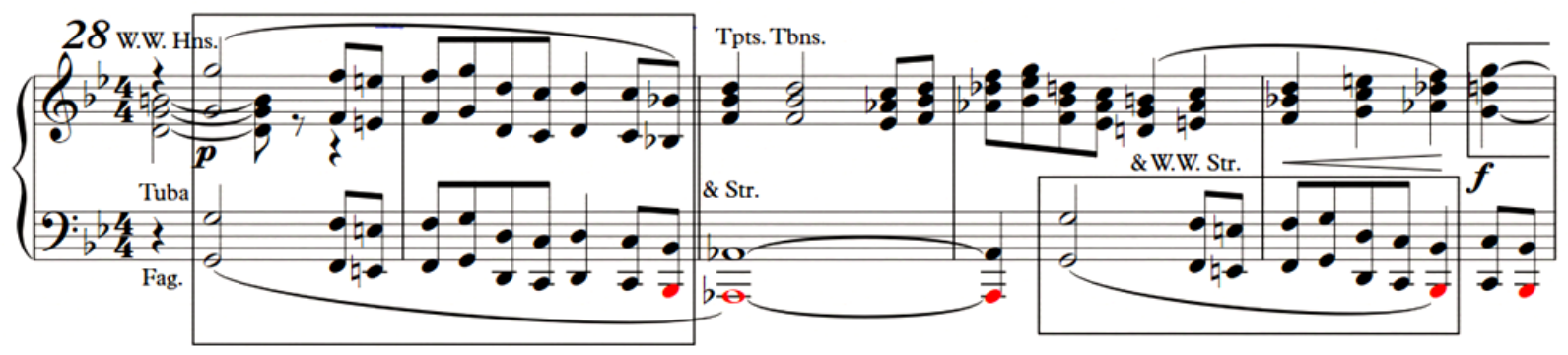

Blessing-curse theme on D aeolian

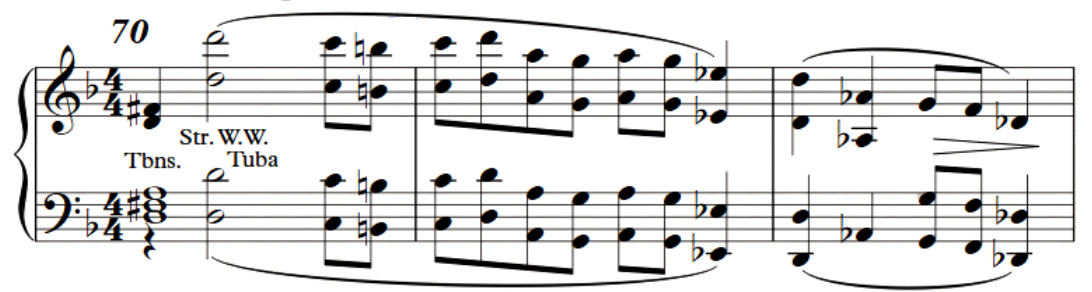

Figure 3-16 The blessing-curse theme in 'The March of The Three Kings' (m.28-32) and (m.7072) (C) Oxford University Press 1954. Extracts from vocal score reproduced by permission.

In the 'Epilogue,' new pitches and triplets are added to the blessing-curse theme, and it is changed to G, F\#, E, C, Eb, D, and C. Thus the theme is lengthened and slightly changed from the original form. It usually appears in C lydian, but as shown in figure 3-17 it begins in $\mathrm{Ab}$ lydian.

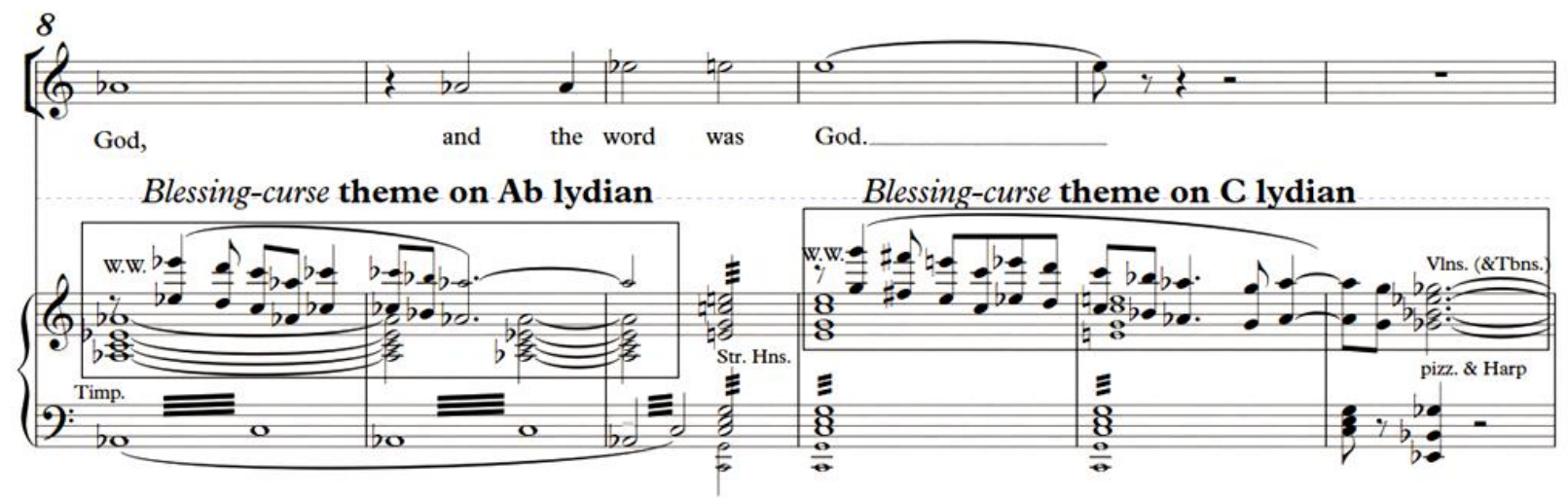



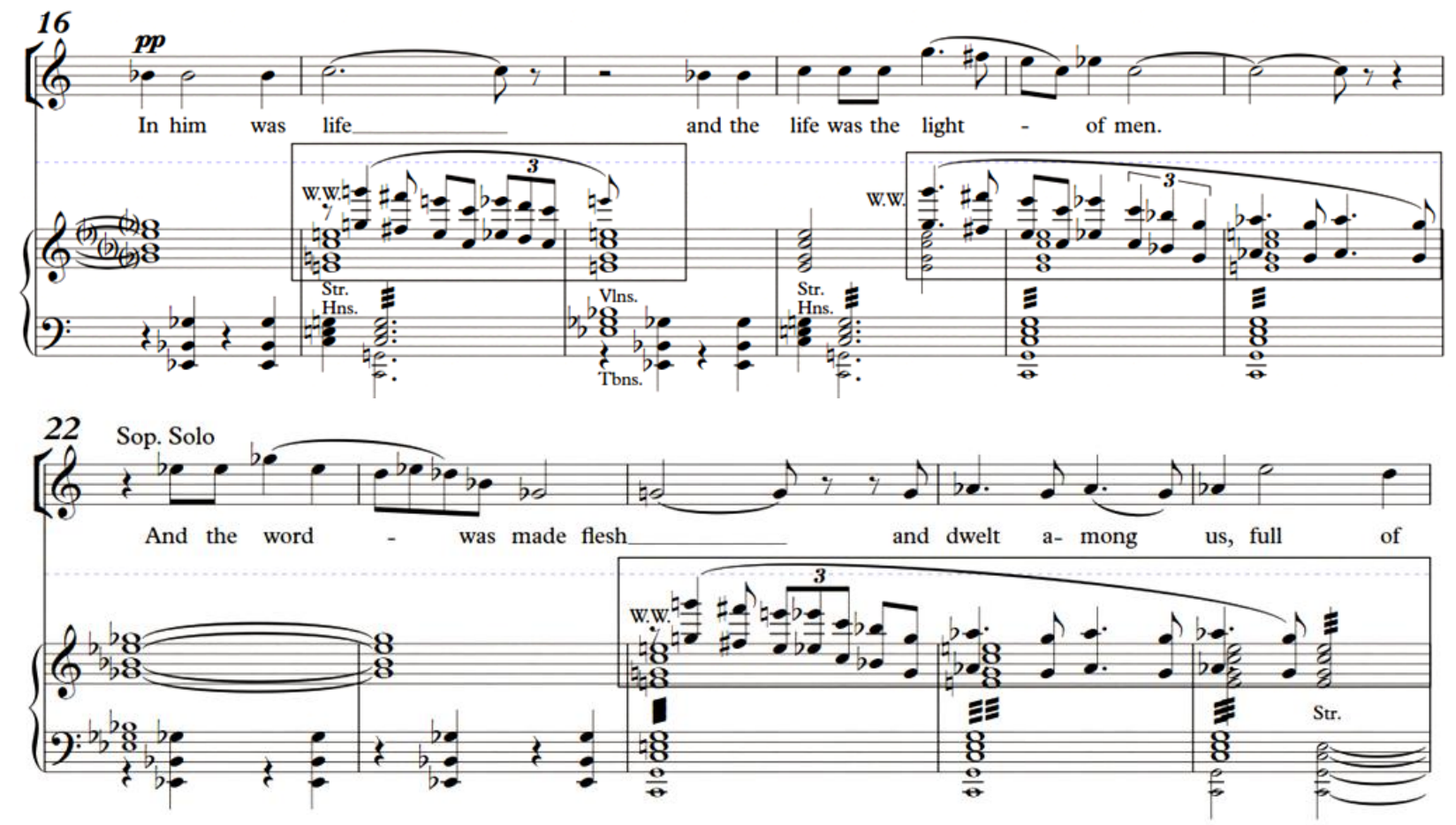

Figure 3-17 The blessing-curse theme in the 'Epilogue' (m.8-26)

(c) Oxford University Press 1954. Extracts from vocal score reproduced by permission.

\section{The Fanfare Theme}

The Fanfare theme basically consists of four patterns of major and minor chords in parallel motion and in triplets. The pattern is as follows: the initial chord is a C major chord, followed by a descending A minor chord before the $\mathrm{C}$ major chord returns. After that, Db major, $\mathrm{C}$ major, and A minor chords appear consecutively in triplets. Finally the $\mathrm{C}$ major chord returns. This pattern is repeated once more. However, the theme changes slightly in the other movements by adding other chords or through modulation. The Fanfare theme occurs in Narrations II and VI, as well as in the poetic insertions, 'The March of the Three Kings' and the 'Epilogue.' Except for 'The March of the Three Kings,' the three movements center in C major. The major and minor triads are the main elements of the theme. However, various augmented, diminished, and altered 
chords are added. The theme usually appears in the brass, but in 'The March of the Three Kings' it occurs in the three solos, the mixed choir, and the orchestra with many modulations.

Table 3.7 The Fanfare theme

\begin{tabular}{|c|c|c|c|c|}
\hline & Narration II & Narration VI & $\begin{array}{c}\text { The March of the } \\
\text { Three Kings }\end{array}$ & Epilogue \\
\hline Length & $\begin{array}{l}\text { m.51-52, m.59-62 } \\
\text { m.66-69 }\end{array}$ & m.32-33 & $\begin{array}{l}\text { m.54-57, m.68-109, } \\
\text { m.137-165 }\end{array}$ & $\mathrm{m} .28-36$ \\
\hline Key & C major & $\mathrm{C}$ major & $\begin{array}{l}\mathrm{D} \text { aeolian, } \mathrm{D} \text { major, } \\
\mathrm{Bb} \text { aeolian (Db major), } \\
\mathrm{Bb} \text { major, } \mathrm{G} \text { major, } \\
\text { and } \mathrm{D} \text { major. }\end{array}$ & $\mathrm{C}$ major \\
\hline Content & $\begin{array}{l}\text { Triplets in parallel } \\
\text { motion of major } \\
\text { and minor chords. }\end{array}$ & $\begin{array}{l}\text { Triplets in parallel } \\
\text { motion of major } \\
\text { and minor chords. }\end{array}$ & $\begin{array}{l}\text { Triplets in unison and } \\
\text { parallel motion of } \\
\text { perfect fifth, triads } \\
\text { (including major, } \\
\text { minor, augmented, } \\
\text { diminished, and added } \\
\text { chords. }\end{array}$ & $\begin{array}{l}\text { Triplets, Parallel } \\
\text { motion of major, } \\
\text { augmented, } \\
\text { added chords, } \\
\text { and altered } \\
\text { chords. }\end{array}$ \\
\hline Instrumentation & Brass & Brass & $\begin{array}{l}\text { Soloists, mixed choir, } \\
\text { and orchestra }\end{array}$ & Brass \\
\hline
\end{tabular}

The fanfare theme initially appears in three places in Narration II (m.51-52, m.59-62, and m.66-69). The theme becomes longer as it goes on, and moves around the $\mathrm{C}$ major chord. It consists of major and minor triads in triplets, and usually occurs in the brass. Figure 3-18 introduces the fanfare theme, and figure 3-19 presents the fanfare theme extended in descending motion.

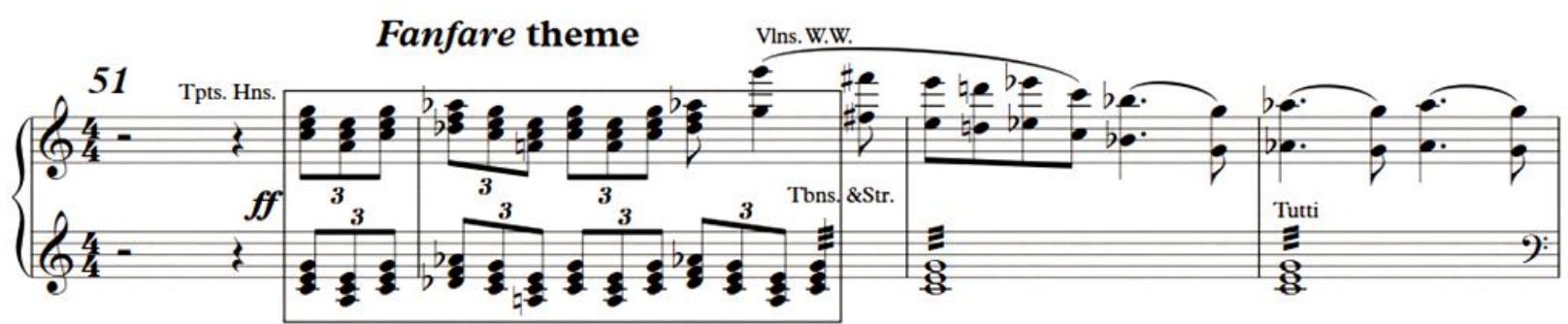

Figure 3-18 The fanfare theme in Narration II (m.51-54) (C) Oxford University Press 1954. Extracts from vocal score reproduced by permission. 


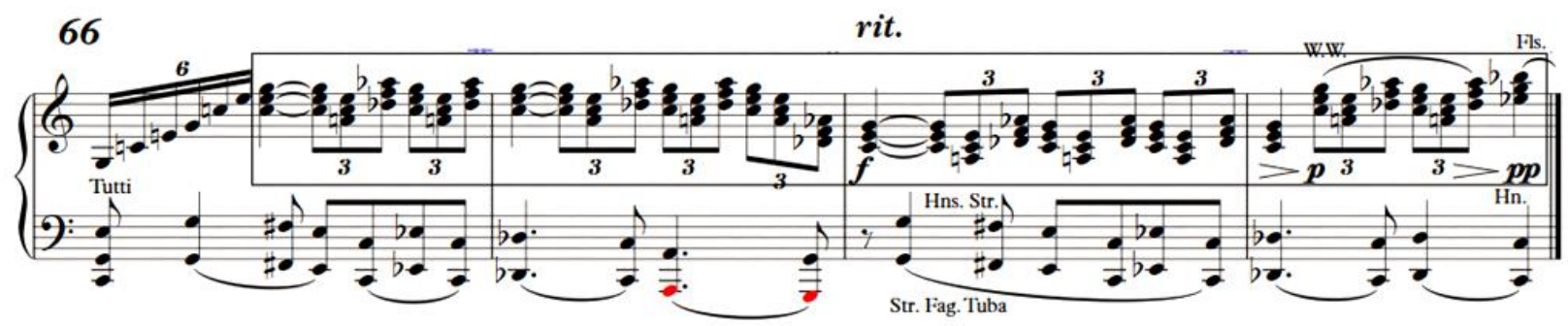

Figure 3-19 The fanfare theme in Narration II (m.66-69)

(C) Oxford University Press 1954. Extracts from vocal score reproduced by permission.

The theme is recalled briefly in Narration VI. As shown in fugure 3-20, it consists of major and minor triads, which move around $\mathrm{C}$ major chords.

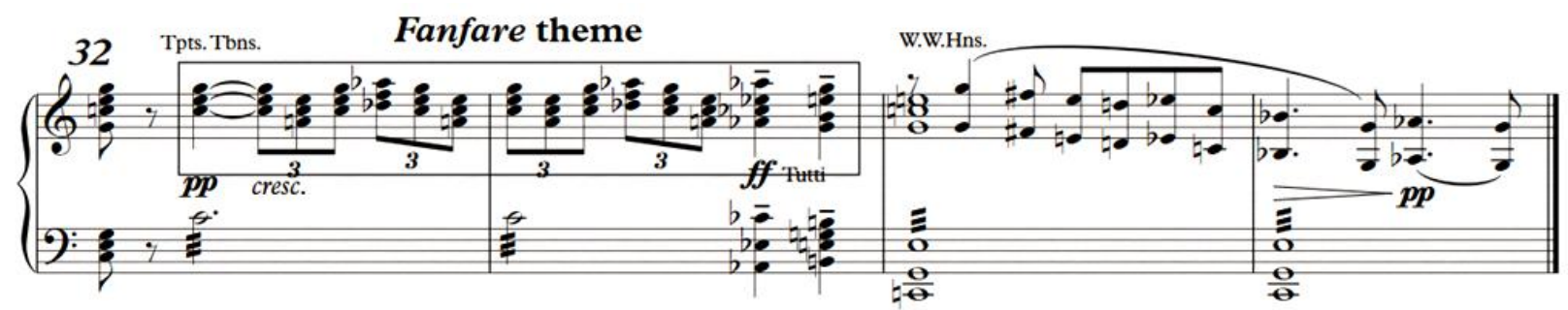

Figure 3-20 The fanfare theme in Narration VI (m.32-35)

(C) Oxford University Press 1954. Extracts from vocal score reproduced by permission.

The fanfare theme is presented in various harmonies with major, minor, augmented, diminished, and added chords as triplets in "The March of the Three Kings." It not only appears in triads and perfect fifths in parallel motion, but also in several keys. The theme is frequently found in the parts for soloists, mixed choir, and orchestra. Figure 3-21 presents the fanfare theme in D major in the brass, and figure 3-22 shows the fanfare theme in Db major in unison with the mixed choir and orchestra. In figure 3-23 the extended fanfare theme appears as major, minor, augmented, diminished, and added chords in triplets. 


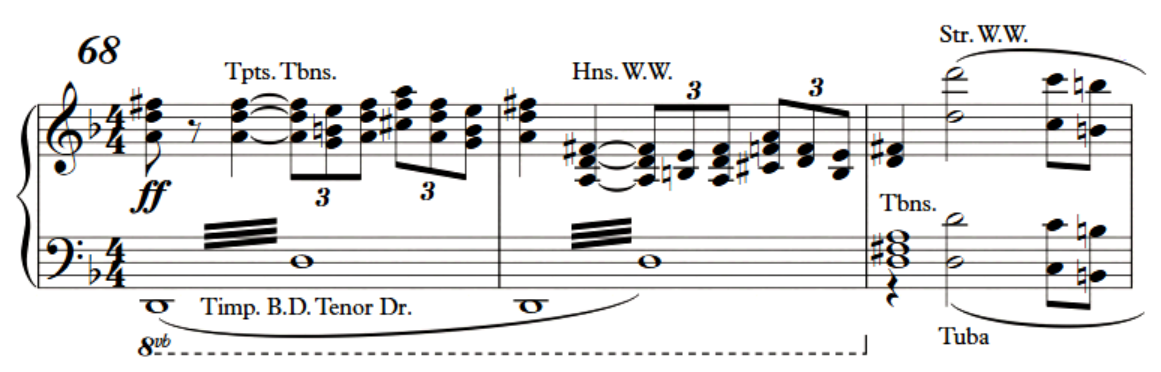

Figure 3-21 The fanfare theme in 'The March of the Three Kings' (m.68-70)

(C) Oxford University Press 1954. Extracts from vocal score reproduced by permission.

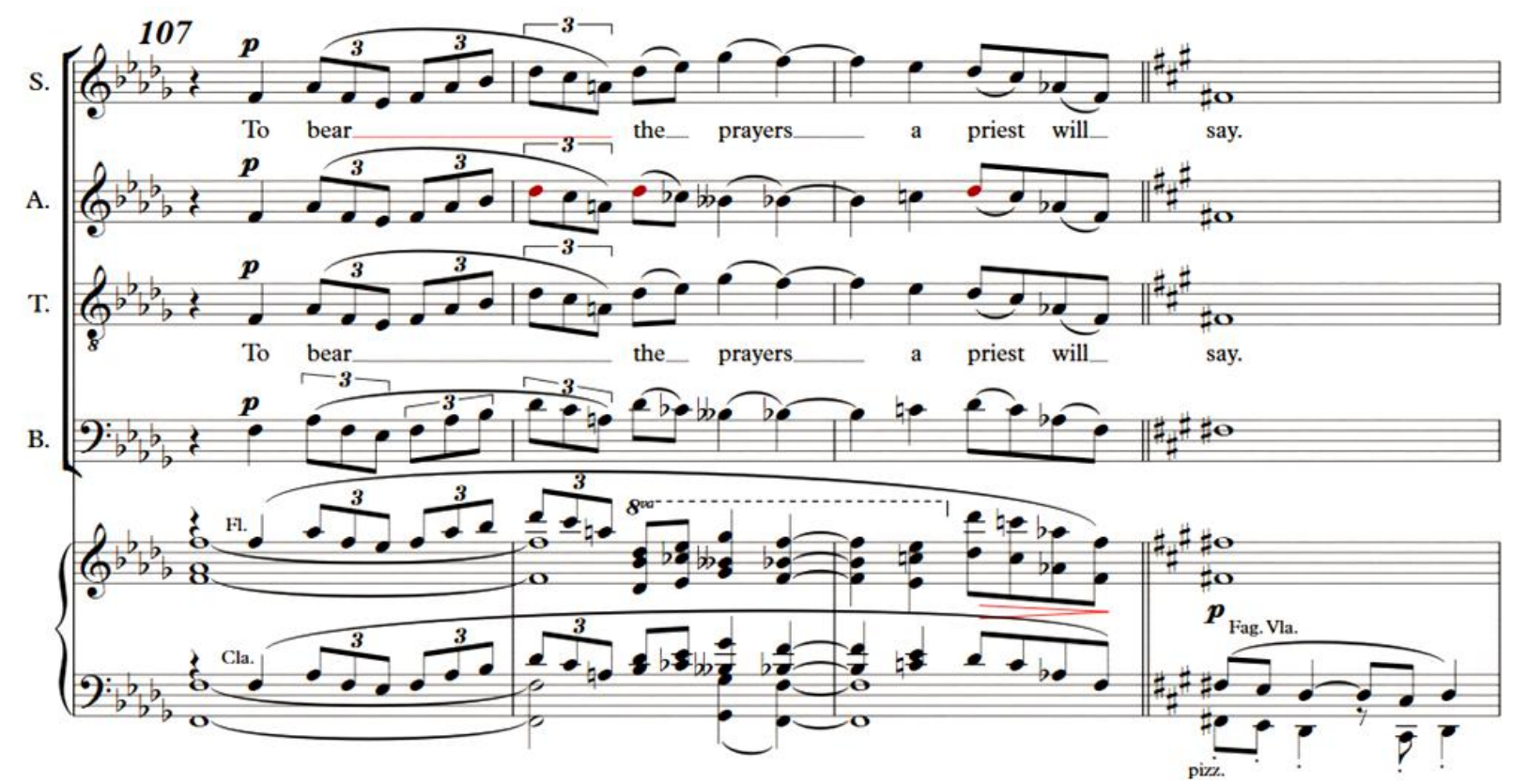

Figure 3-22 The fanfare theme in 'The March of the Three Kings' (m.107-110)

(C) Oxford University Press 1954. Extracts from vocal score reproduced by permission.

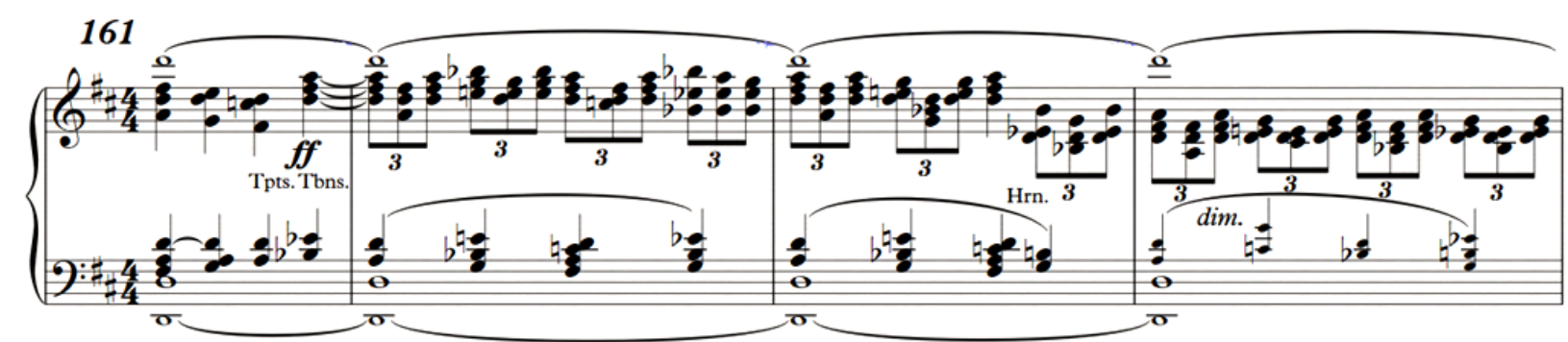

Figure 3-23 The fanfare theme in 'The March of the Three Kings' (m.161-164)

(C) Oxford University Press 1954. Extracts from vocal score reproduced by permission. 
The Fanfare theme is recalled at the end of the first part of the 'Epilogue,' where the harmony has become more complicated as indicated in figure 3-24.

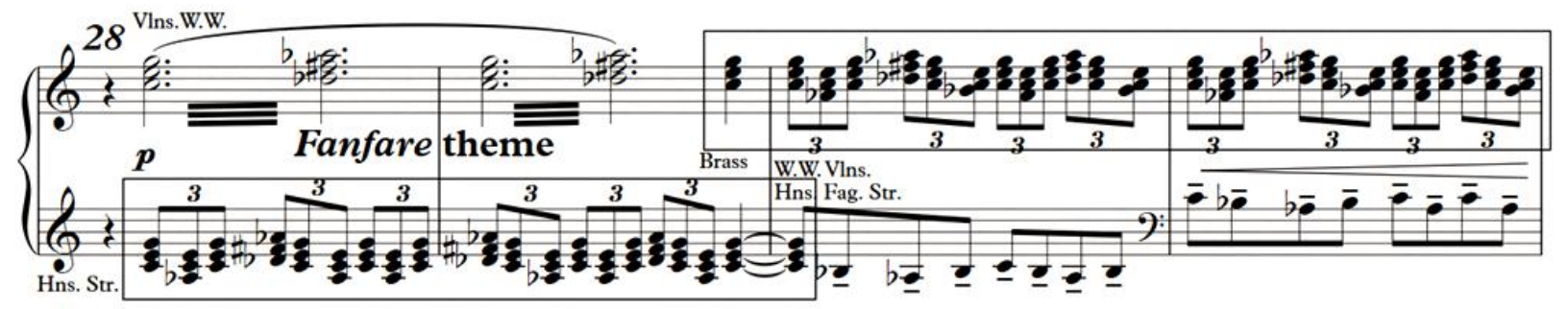

Figure 3-24 The Fanfare theme in the Epilogue (m.28-31)

(C) Oxford University Press 1954. Extracts from vocal score reproduced by permission.

\section{The 'Emmanuel, God with Us' Theme}

The 'Emmanuel, God with us' theme appears in Narration II and the 'Epilogue.' The theme is presented in the mixed choir (or soloists) with the fanfare and the blessing-curse themes in the orchestral accompaniment. As shown in table 3.8, the theme varies in length, harmony, and choral/orchestra forces, while the text and the key remain the same.

Table 3.8 The 'Emmanuel, God with us' theme

\begin{tabular}{l|l|l} 
& \multicolumn{1}{|c|}{ Narration II } & \multicolumn{1}{c}{ 'Epilogue' } \\
\hline Length & 5 measures & 7 measures \\
\hline Choral/orchestra forces & Mixed choir & $\begin{array}{l}\text { Soprano, tenor, baritone } \\
\text { soloists, and mixed choir }\end{array}$ \\
\hline Contents & $\begin{array}{l}\text { Combining blessing-curse } \\
\text { and fanfare themes } \\
\text { consisting of triplets with } \\
\text { major and minor chords }\end{array}$ & $\begin{array}{l}\text { Combining blessing-curse and } \\
\text { fanfare themes consisting of } \\
\text { triplets with major, minor, } \\
\text { diminish, augmented, altered, } \\
\text { and added chords }\end{array}$ \\
\hline Text & $\begin{array}{l}\text { 'Emmanuel, Emmanuel, } \\
\text { God with us' }\end{array}$ & $\begin{array}{l}\text { 'Emmanuel, Emmanuel, } \\
\text { God with us' }\end{array}$ \\
\hline Key & $\begin{array}{l}\text { C lydian (sustaining C } \\
\text { major chord) }\end{array}$ & $\begin{array}{l}\text { C lydian (sustaining C major } \\
\text { chord) }\end{array}$ \\
\hline
\end{tabular}


Figures 3-25 and 3-26 present the 'Emmanuel, God with us' theme as it appears in Narration II and the 'Epilogue.' In Narration II, the theme appears in C major although other chords are inserted between $\mathrm{C}$ major triads. It is also found in the mixed choir at the end of the movement with the fanfare and the blessing-curse themes as an accompaniment. In the 'Epilogue,' the 'Emmanuel, God with us' theme is extended and three soloists are added. As in Narration II, the fanfare and the blessing-curse themes are heard with the 'Emmanuel, God with us' theme, but the harmony of the fanfare theme is diversified by major, minor, diminished, augmented, altered, and added chords.

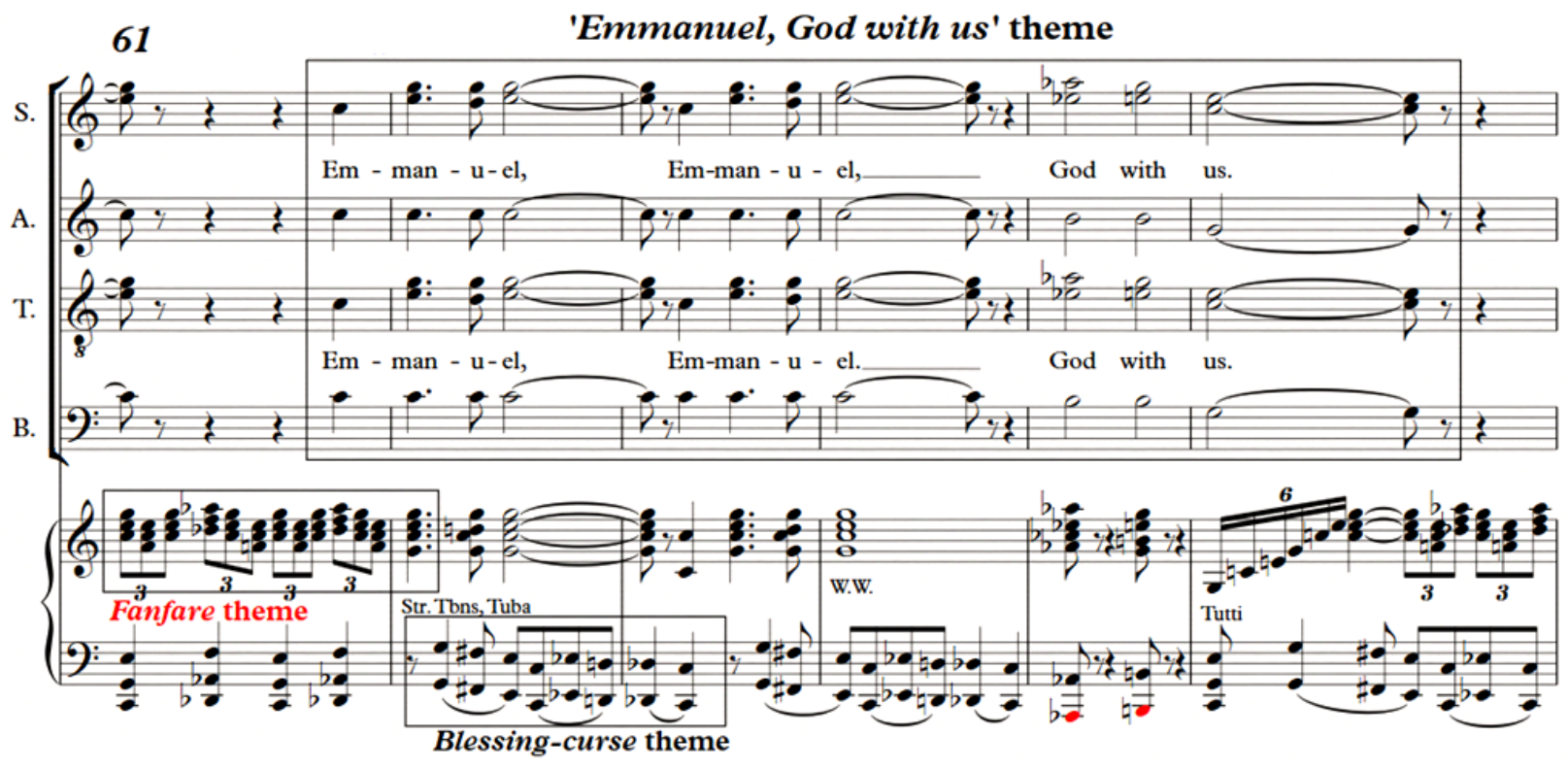

Figure 3-25 The 'Emmanuel, God with us' theme in Narration II (m.61-66) (C) Oxford University Press 1954. Extracts from vocal score reproduced by permission. 
'Emmanuel, God with us' theme
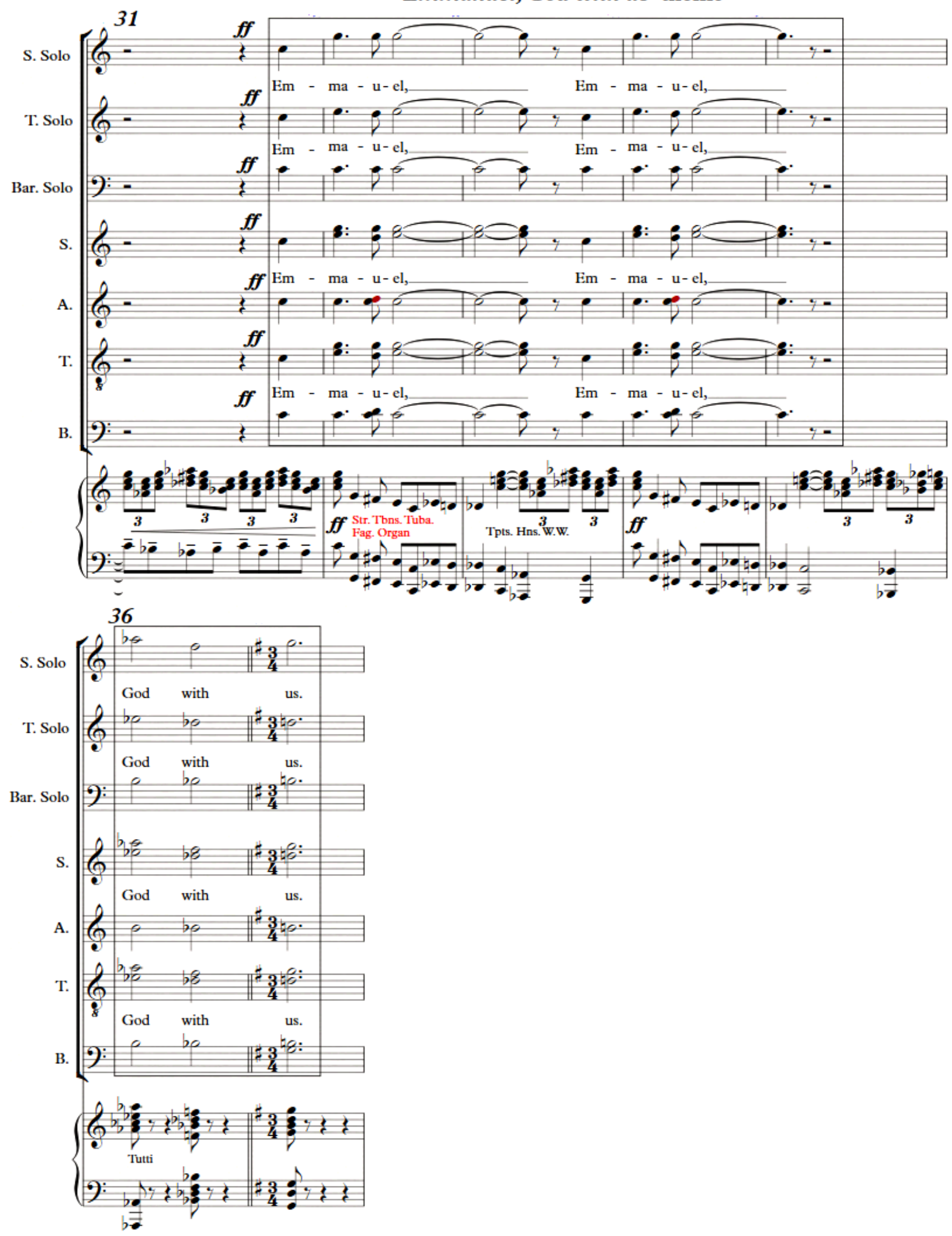

Figure 3-26 The 'Emmanuel, God with us' theme in the 'Epilogue' (m.31-37)

(C) Oxford University Press 1954. Extracts from vocal score reproduced by permission. 


\section{Other Themes}

The alternating $F$ sharp minor and $F$ minor chords and the rising bass line themes are presented ${ }^{26}$ with the blessing-curse, the fanfare, and the 'Emmanuel, God with us' themes in Narration II and the 'Epilogue.' In Narration II, they appear in measures 40 to 42 during the tenor solo, while in the 'Epilogue,' they occur in measures 1 to 2 in orchestra.

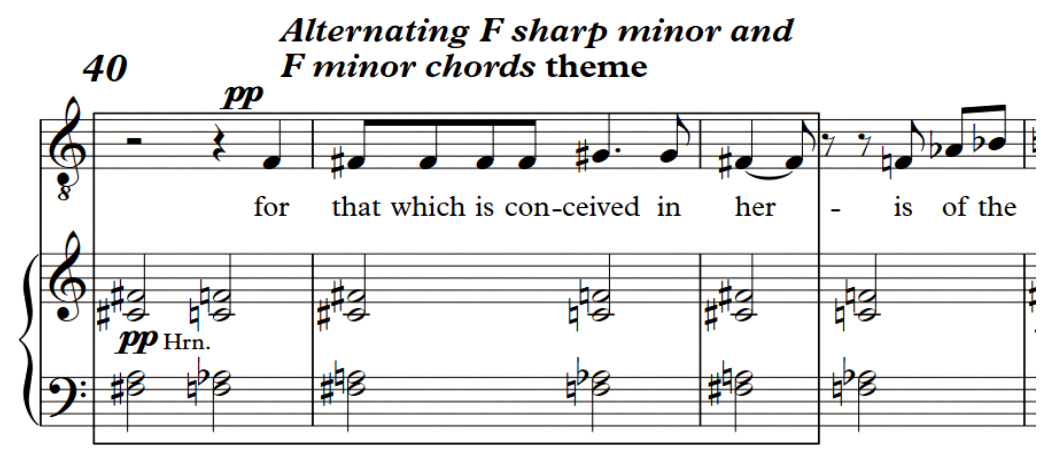

Figure 3-27 The alternating $F$ sharp minor and $F$ minor chords theme in Narration II (m.40-42) (C) Oxford University Press 1954. Extracts from vocal score reproduced by permission.

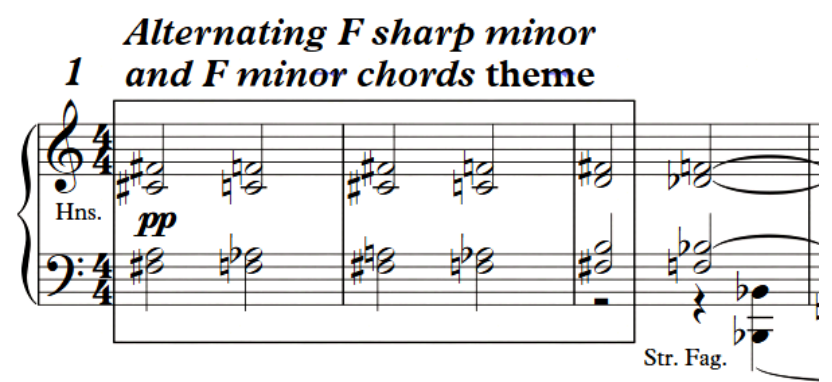

Figure 3-28 The alternating $F$ sharp minor and $F$ minor chords theme in the 'Epilogue' (m.1-2) (C) Oxford University Press 1954. Extracts from vocal score reproduced by permission.

The rising bass line theme appears after the alternating $F$ sharp minor and $F$ minor chords theme. It is first heard in the orchestra (strings and bassoons), imitated by the tenor and baritone solos a minor third higher. Mellers comments that:

\footnotetext{
${ }^{26}$ Etter introduces the themes in his dissertation.
} 
The Angel veers between such dramatically impassioned outbursts and syllabic narration similar to that of the boys, though his fluctuating concords (between F sharp major and F minor) are far more falsely mysterious, recalling the desolation of Riders to the Sea and related passages in the Six and Seventh Symphonies. ${ }^{27}$

Figures 3-29 and 3-30 show the rising bass line theme in Narration II and the 'Epilogue.' The length and pitches of the theme are almost the same in both movements. However, in the 'Epilogue,' the rhythms in the baritone solo change, and 4/4 meter changes to 2/4 at the end of the movement.

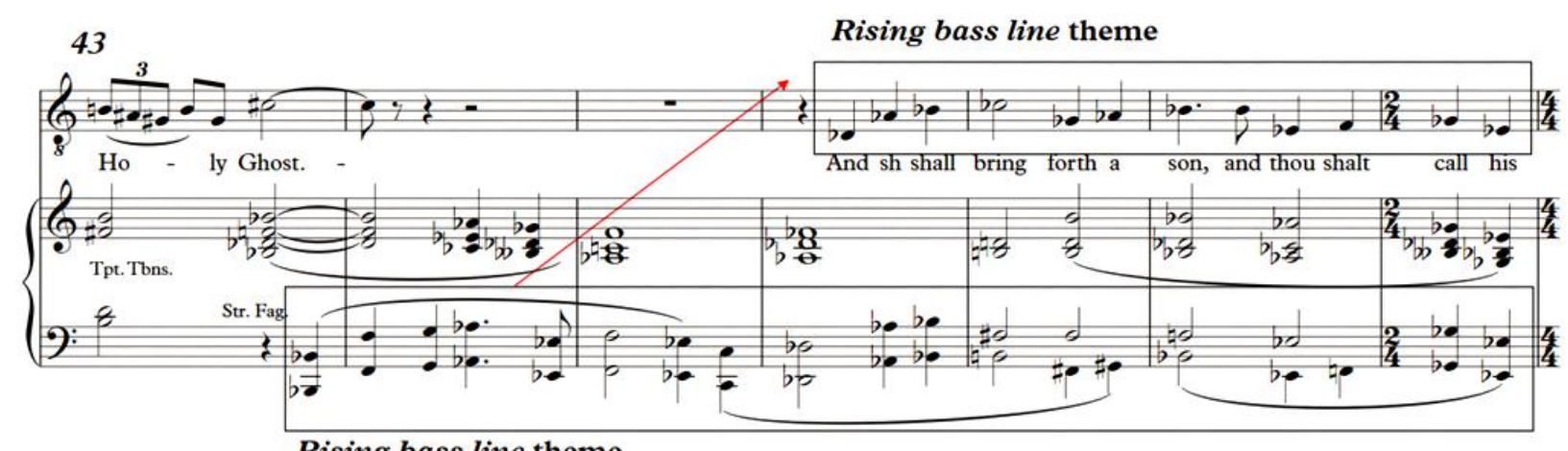

Rising bass line theme

Figure 3-29 The rising bass line theme in Narration II (m.43-49)

(C) Oxford University Press 1954. Extracts from vocal score reproduced by permission.

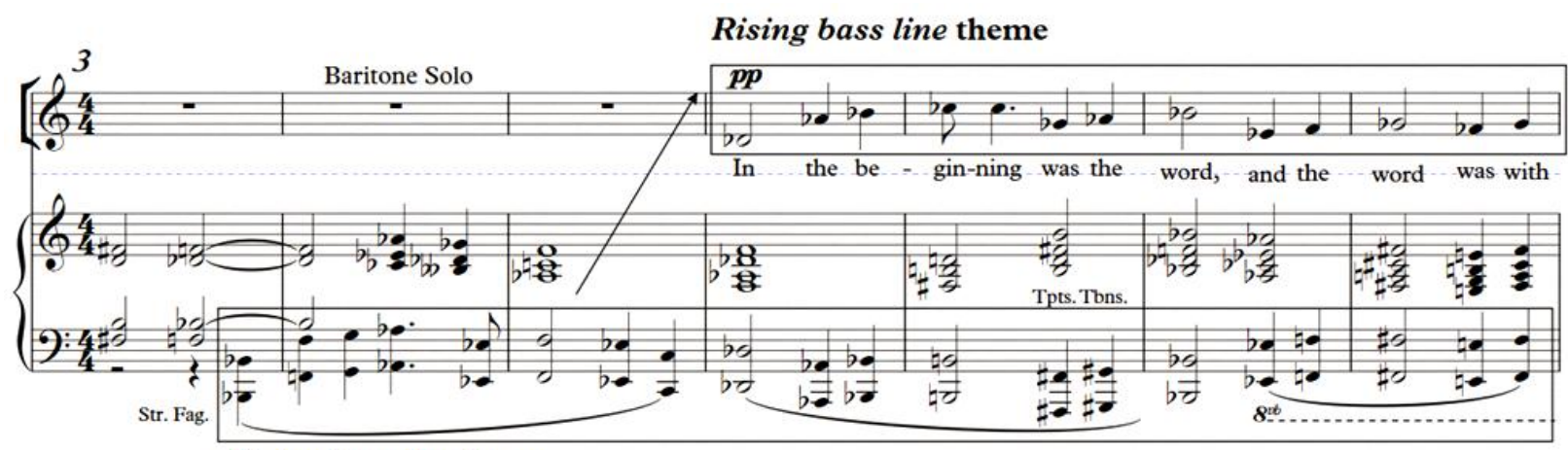

Rising bass line theme

Figure 3-30 The rising bass line theme in the 'Epilogue' (m.3-9)

(C) Oxford University Press 1954. Extracts from vocal score reproduced by permission.

\footnotetext{
${ }^{27}$ Mellers, 212.
} 


\section{Conclusion}

The recurring appearance of nine contrasting themes emerges as a significant compositional strategy which unifies the sixteen different movements of Hodie.

Table 3.9 The Style of Recurring Themes

\begin{tabular}{|c|c|c|c|}
\hline \multirow[b]{3}{*}{ Themes } & \multirow{3}{*}{$\begin{array}{l}\text { Recurring Narrative Themes } \\
\text { Boy evangelists themes } 1,2,3 \text {. }\end{array}$} & \multicolumn{2}{|c|}{ Recurring musical Ideas } \\
\hline & & $\begin{array}{l}\text { Correlation between } \\
\text { text and music }\end{array}$ & $\begin{array}{c}\text { Non-correlation between } \\
\text { text and music }\end{array}$ \\
\hline & & $\begin{array}{l}\text { Gloria theme, } \\
\text { 'Emmanuel, God } \\
\text { with us' theme. }\end{array}$ & $\begin{array}{l}\text { Blessing-curse theme, } \\
\text { Fanfare theme, } \\
\text { Alternating F sharp minor } \\
\text { and F minor chords theme, } \\
\text { Rising bass line theme. }\end{array}$ \\
\hline Characteristic & Focusing on telling the story & \multicolumn{2}{|c|}{ Focusing on presenting musical ideas } \\
\hline $\begin{array}{l}\text { Compositional } \\
\text { techniques }\end{array}$ & $\begin{array}{l}\text { The length of the themes depends } \\
\text { on text. } \\
\text { The themes contain triplets and } \\
\text { pentatonic figurations in common } \\
\text { although the musical ideas of } \\
\text { each theme are different. }\end{array}$ & \multicolumn{2}{|c|}{$\begin{array}{l}\text { Meter, key (mode), length (lengthened or } \\
\text { shortened), orchestral or choral force, and harmony } \\
\text { are changed whenever the themes reappear in other } \\
\text { movements. }\end{array}$} \\
\hline
\end{tabular}

The boy evangelists themes 1, 2, 3 in a narrative style focus on the telling of the biblical account. The themes are lengthened and shortened according to the text. Harmony, key (mode), meter, dynamics, orchestration, and rhythm also vary while the triplets and pentatonic figurations, the basic characteristics of these themes, remain unchanged. Thus, variety as well as unity is simultaneously realized.

The remaining themes present recognizable musical ideas which recur throughout the work. No connection between text and music can be found for the blessing-curse, the fanfare, the alternating $F$ sharp minor and $F$ minor chords, and the rising bass line themes. Since these themes do not depend on or correlate with text, they do not change. They are scored for orchestra, 
choir, or soloist regardless of text and appear in a number of contexts, lending musical coherence and logic to the work.

The Gloria and the Emmanuel God with Us themes consistently correlate with these texts. Scored for the orchestra as well as the choir, these themes are present as reminders of these ideas, tracing the joy of Christ's birth and God's presence throughout the work. Changes in meter, key (mode), length, harmony when these themes appear provides variety.

Recurring themes as a compositional strategy appear in other large choral works by Vaughan Williams. However, it is in Hodie, a late work, that the recurring themes are used systematically. It is in this mature work that the composer turns to a number of diverse compositional techniques which brilliantly convey the mystery and joy of the birth of Christ. 


\section{Chapter 4. Hodie, Dona Nobis Pacem, and Sancta Civitas: A Comparison of Stylistic Change}

Vaughan Williams's artistic creed has always been that the composer must not live a life apart, that he must 'cultivate a sense of musical citizenship,' that he must not 'shut himself up and think about art, he must live with his fellows and make his art an expression of the whole life of the community.'

Vaughan Williams composed twenty-six large choral works. They reflect his beliefs and philosophies as well as reveal distinctive compositional strategies that embrace "an extraordinarily wide stylistic and expressive vocabulary." ${ }^{2}$ By combining tonality and modality, Vaughan Williams created a unique musical style that differed from his contemporaries. This chapter will compare the musical style of Hodie with Dona Nobis Pacem and Sancta Civitas, the composer's other large-scale works on sacred texts.

\section{Combining Tonality and Modality}

Vaughan Williams followed a musical style from the past that was based on tonality, despite new contemporary approaches which rejected tonality. ${ }^{3}$ The combination of modality and tonality emerges as a crucial characteristic of Vaughan Williams's musical style. Through the introduction of church modes he persisted to follow an approach characterized by

\footnotetext{
${ }^{1}$ Frank Stewart Howes. The Music of Ralph Vaughan Williams. London: Oxford University Press, 1954: 165

${ }^{2}$ Alain Frogley. Vaughan Williams: Hodie (A Christmas Cantata). CD Booklet. Musical Heritage: London. 1990: 3 .

${ }^{3}$ Michael Kennedy. The Works of Ralph Vaughan Williams. London: Oxford University Press, 1964: 186.
} 
"uncompromising individuality, tunefulness, with extraordinary range and diversity within a

steadily forged and assertive style. ${ }^{4}$ Wilfrid Mellers comments that:

One of the consequence of the poly-modality of the war-time and post-war works was that during the twenties Vaughan Williams produced his most harmonically adventurous music, since works such as Sancta Civitas, the Magnificat and the Piano Concerto have surrendered a serenely accepted (folk-like) modalism without acquiring the will-full certitude of tempered tonality. ${ }^{5}$

Thus, Hodie presents a musical style based on tonality and poly-modality. It was a style that he had pursed throughout his life in his other works and one which other composers, like Mahler, had used before. Michael Kennedy observes that:

It is rare in the twentieth century for an artist to enjoy the feeling of complete communication with the unsophisticated as well as with the professionals of his art. His style, therefore, became the perfect instrument for that communication. His so-called 'uncompromising' language is in reality an inspired use of simple effects, of blocks of chords, of keys bluntly juxtaposed $-\mathrm{C}$ major and $\mathrm{E}$ flat in Hodie, $\mathrm{D}$ flat against $\mathrm{C}$ in the Fourth Symphony, a device much favoured by another composer, Mahler, who had the secret of conveying his most personal thought in direct musical terms through the expressive use of "false relations. ${ }^{6}$

\section{Recreating New Meaning from Biblical Text and English Poetry}

The characteristics of his large choral works were essentially determined by the texts. As discussed in Chapter II, biblical texts were enhanced and recreated with new meaning from English poetry drawn from the sixteenth to the twentieth centuries. The choice of texts reflects his beliefs and philosophies as well as his reactions to the contemporary social and political

\footnotetext{
${ }^{4}$ Michael Kennedy. "Vaughan Williams at Eighty-Five." The Musical Times 98, no. 1376 (October 1957): 545.

${ }^{5}$ Wilfrid Meller. Vaughan Williams and the Vision of Albion. Illminster: Albion Music, 1997: 242.

${ }^{6}$ Kennedy (1964), 371.
} 
environment. ${ }^{7}$ Musical form, texture, and harmony were determined by the text. A. E. F.

Dickinson has observed:

In Sancta Civitas, for example, there is line but no tune to substantiate the apocalyptic vision of heaven above and Babylon beneath. This is mainly effected by a changing harmony of superimposed fourths (and whatever), chromatic and modal strips of vocal phrase, up to three notes deep, and an oscillation between a declamatory and a more shapely vocal line...In Hodie, resurgent melody welcomes the four verses of Milton's Ode, the last for the strong man's optative 'Truth and justice will then appear,' absorbing the earlier 'Nowell' spasms and lighter strophes, while Sancta Civitas and The Pilgrim's Progress elements thrust home intimations of 'Immanuel.,

Frank Stewart Howes, a music critic and author adds that:

In Dona Nobis Pacem, this distracted political life of the nineteen-thirties and its overshadowing fear of universal war are not here being used as a quarry for matter subsequently to be turned into art by recollection in tranquility; rather it called for a pamphlet from a composer who is aware of the claims of his citizenship... This is not to deny that the central idea is strong enough to unify the component ideas of war, reconciliation, mourning, and the conquest of fear, only to doubt whether the internal balance and proportion are quite what they would have been had the work been designed in its entirety before any of the music was composed. ${ }^{9}$

Mellers explains that the composer's Christian agnosticism emerges in Sancta Civitas, a work composed 1926:

Ethical and political implications were overt in its vision of the City's disaffection; wars and rumours of war, apocalyptic disasters were rife in the world at large; the first performance [of Sancta Citivas,] Michael Kennedy tells us, took place in the turmoil of the General Strike. Even so, the social and political aspects are a physical backcloth; at heart the piece is metaphysical, demonstrating how - as Vaughan Williams had put it in 1920, when asked to define an aesthetic creed - 'the object of all art is to obtain a partial revelation of what is beyond human sense and human faculties.' Not for nothing did he

\footnotetext{
${ }^{7}$ According to Mellers, 131, "The religious, social, and political implications colour most of the works of Vaughan Williams's later maturity, whether they carry a literary text or function by way of symphonic argument."

${ }^{8}$ A. E. F. Dickinson. “Obituaries,” Tempo, no. 49 (Autumn 1958): 34.

${ }^{9}$ Howes, 165-6.
} 
preface his score with words (in Greek) from Plato's Phaedo - words which bear directly on the composer's Christian agnosticism: 'A man of sense will not insist that things are exactly as I have described them. But I think he will believe that something of the kind is true of the soul and her habitations, seeing that she is shown to be immortal, and that it is worthwhile to stake everything on this belief. The venture is a fair one, and he must charm his doubts with spells like these. (Author's italics.) ${ }^{10}$

Andrew Burn also comments that:

In Sancta Civitas (The Holy City), Vaughan Williams arguably revealed his beliefs as man and artist more than in any other of his compositions... By this time Vaughan Williams described himself as 'a cheerful agnostic,' but one who was nevertheless steeped in the tradition of the Anglican Church, so that by choosing texts with which his audiences were familiar they could be used as powerful symbols. Here the biblical words and the battle between good and evil become a symbol of humankind's destructive nature and its severance from the natural order. The burning intensity of the message of Sancta Civitas is still only too relevant today. ${ }^{11}$

His thoughts concerning the current social or political situation in England were presented in Dona Nobis Pacem (1936), a work that reflected "the unstable political situation of the 1930s sliding disastrously towards another war." ${ }^{12}$ Kennedy explains that:

Only one work in the period $1936-9$ can be directly related to the contemporary scene and in that, Dona Nobis Pacem, there is throughout a note of optimism, a faith held by most of Britain at that time that the clouds would pass away. In the finale, before its hushed last prayer, the bells ring and the chorus sing of a vision of peace. ${ }^{13}$

However, Hodie was composed with a different purpose in mind. Unlike Sancta Civitas and Dona Nobis Pacem, Hodie is "unemotional with a minimum of the dramatic, in recitative

\footnotetext{
${ }^{10}$ Mellers, 135.

${ }^{11}$ Andrew Burn. Dona nobis pacem and Sancta Civitas. CD Booklet. Naxos: Canada. 2010: 3.

${ }^{12}$ Burn, 4.

${ }^{13}$ Kennedy (1964), 265.
} 
style." ${ }^{14}$ It is "filled with a grace, mellow naìveté, and youthful exuberance quite unlike any of his previous cantatas. ${ }^{\prime 15}$ Emphasizing mysticism instead of belief, Hodie recreates the biblical story of Jesus into 'Christmas myth,' by integrating biblical and non-biblical texts. Mellers observes that:

Now, in old age, he sees the Christmas story as that of the Boy who was born: thereby echoing the title of the first major work of Britten's adolescent genius and demonstrating, no less than the young man's piece, how deeply the Christmas myth may be relevant to our bruised and battered century. Even so, it is significant that Vaughan Williams should treat the story archetypically (in the Jungian sense), setting it in a traditionally Christian social context. England's past, as well as the individual psyche, is here renascent, the convention being that of a pristine English oratorio, merged into an Anglicized version of the Bachian Passion or sacred history - a convention which, by then, was a part of English life. ${ }^{16}$

Thus, the combination of biblical and non-biblical text can be seen as one of Vaughan

Williams's unique compositional techniques. Through music, Vaughan Williams tried to express his reactions to his surrounding environment because he believed that music was an integral part of the life of his community and nation. In other words, Vaughan Williams used music as a communication with his community, and chose subjects that were understood and engendered empathy from his listeners. Therefore, his creed was reflected by Hodie, Sancta Civitas, and

\section{Dona Nobis Pacem.}

14 "Both James Day and Wilfrid Mellers compare this to the style of Schütz (1585-1672). Day asserts that 'the mellifluous stylized narration - back to the kind of folky Schütz in an unexpectedly jovial mood rather than to Bach, enhances the early Renaissance feeling.' Mellers, comparing this narration technique to those from music's history, states: 'the parallel is perhaps with the sacred histories of Bach's predecessor Heinrich Schütz (which Vaughan Williams knew and loved), rather than with Tudor liturgical music itself,' (Both authors mention Bach due to critic's comparisons of Hodie with Bach's Passions and Christmas Oratorio,..., which, with each providing arias, chorales, choruses, and recitative, do have similarities.” Etter, 94-5.

${ }^{15}$ Kennedy (1964), 364.

${ }^{16}$ Mellers, 209-10. 


\section{Intensive and Majestic Orchestration}

Vaughan Williams's orchestration exerted considerably influence on his musical style. His music was dramatically maximized through brilliant and colorful orchestration not without some criticism as thick, intensive, and 'expertly kept busy.' He preferred large-scale genres. Thus, his many works were scored for various choirs or instruments, including soloists (soprano, alto, tenor, and baritone), choirs (mixed, semi, women's, men's, and boy's choirs) as well as full orchestra (including church organ and distant instruments). The wide range of his instrumentation made possible its emotional appeal. Simon Heffer observes that:

...Vaughan Williams wrote the suite [Sancta Civitas] for a large orchestra, enabling him to create a majesty of sound and a gravity of tone still unusual in his work, though apparent to an extent in Sancta Civitas. ${ }^{17}$ In using such large forces he risked stumbling because of his old Achilles heel, orchestration. Holst was at the Norwich rehearsal, and Arthur Bliss, sitting next to him, recalled his listening with 'frightening intensity.'... At once a greater command of orchestration is apparent in music of $J o b$, as well as a profound emotional intensity not always obvious in Vaughan Williams's work before, and not really heard since his oratorio. ${ }^{18}$

Vaughan Williams's orchestration did not conspicuously change during his long musical career.

During this period, other contemporary composers began to prefer small orchestras as they fell under the influence of new musical trends such as neoclassicism and expressionism. However,

\footnotetext{
17 "Composed 1923-5. An Oratorio for tenor and baritones soloists, mixed chorus, semi chorus, distant chorus, and orchestra...Instrumentation: 3 flutes, 2 oboes, 1 cor anglais, 2 clarinets, 2 bassoons, 1 double bassoons, 4 horns, 3 trumpets, 3 trombones, tuba, percussion (side drum, bass drum, cymbals, pianoforte), harp, organ, strings. The semichorus should sit behind the full chorus and consist of about 20 singers $(6,6,4,4)$. The distant choir should if possible be out of sight and must have a special conductor. It should consist of boy's voices if possible. The distant trumpet must be placed with the distant choir. The tempo marks are approximate. The pace must be free and elastic throughout. First performance in London: Central Hall, Westminster, 9 June 1926. Roy Henderson (baritone), Steuart Wilson (tenor), The Bach Choir, The Temple Choristers, G. Thalben-Ball (organ). London Symphony Orchestra, conducted by Dr. R. Vaughan Williams. Duration: 31 minutes Publication: London, J. Curwen \& Sons Ltd. (@1925 R.V.W.)" Michael Kennedy. A Catalogue of the Works of Ralph Vaughan Williams. ${ }^{\text {nd }}$ ed. London: Oxford University Press, 1982: 115-6.

${ }^{18}$ Heffer, 73 .
} 
Vaughan Williams held fast to his own style without change. Although reading his scores is not easy for performers and conductors, his orchestration is undeniably effective, ${ }^{19}$ clear and imaginative as in Hodie with its intensive and majestic style. Allen L. Borton comments that:

Roy Douglas, one of the composer's most trusted copyists, has described the difficulties and complexities of working on Vaughan Williams's score. 'There were also occasions when I just could not read the notes. My favorite instance of this was in Hodie. I tried one unlikely-looking clarinet passage in $\mathrm{Bb}$ and in $\mathrm{A}$, wondered if it had strayed from the cor anglais line or the bassoon (in tenor or bass clef), but eventually had to give it up and ask him what the notes were meant to be. The reply came back: 'Can't make this out at all, let's leave it out,' and we did. ${ }^{20}$

Thus, Vaughan Williams's orchestration includes dynamic, elaborate, and diverse musical

expressions with intensive and massive sounds, as illustrated in Hodie.

The sixteen numbers make varied use of the orchestral and vocal resources, and of the composer's wide stylistic range, including the innovations in his music that date from around the time of the score for the 1948 film Scott of the Antarctic (the tenor solo 'Bright portals of the sky,' with its 'diamantine,' celestial glitter, is the most obvious example of the 'Antarctic' influence). ${ }^{21}$

\section{Borrowing}

Borrowing musical elements from his own works as well as from those of other composers are an important characteristic of Vaughan Williams's style. When musical elements reappear, they are sometimes changed in style. The borrowings present in Hodie, Sancta Civitas, and Dona Nobis Pacem are listed below.

\footnotetext{
${ }^{19}$ Kennedy (1964), 271.

${ }^{20}$ Allen L. Borton. "Ralph Vaughan Williams’s Hodie at Forty.” Choral Journal 35, no. 5 (December 1994): 17.

${ }^{21}$ Alain Frogley. Vaughan Williams: Hodie (A Christmas Cantata). CD Booklet. Musical Heritage: London.
} 
Table 4.1 Borrowing in Hodie

\begin{tabular}{|c|c|}
\hline $\begin{array}{l}\text { Hodie's musical elements and } \\
\text { compositional techniques }\end{array}$ & $\begin{array}{c}\text { Vaughan Williams's other works } \\
\text { related to Hodie }\end{array}$ \\
\hline Boy evangelists & $\begin{array}{l}\text { The woodcutter's Boy in the Delectable } \\
\text { Mountains scene of The Pilgrim's Progress }\end{array}$ \\
\hline allegro alla tedesca in the first movement & The landler in the Piano concerto ${ }^{23}$ \\
\hline Blessing-curse theme & $J o b^{24}$ \\
\hline $\begin{array}{l}\text { Alternating between } \mathrm{F} \text { sharp major and } \mathrm{F} \\
\text { minor chords theme }\end{array}$ & $\begin{array}{c}\text { Rider to the Sea, } \\
\text { The Sixth and Seventh Symphonies, }{ }^{25} \\
\text { Pilgrim's Progress }{ }^{26}\end{array}$ \\
\hline $\begin{array}{c}\text { Use of celesta, head voice, and triplets in the } \\
\text { third movement }\end{array}$ & Flos Campi $^{27}$ \\
\hline $\begin{array}{l}\text { The quasi-oriental manner }{ }^{28} \text { in the fourteenth } \\
\text { movement }\end{array}$ & March in Flos Campi ${ }^{29}$ \\
\hline Array of texts & Dona Nobis Pacem ${ }^{30}$ \\
\hline Lullaby accompaniment & A Cradle Song ${ }^{31}$ \\
\hline Allegro maestoso in the sixteenth movement & Job (Sons of the Morning) ${ }^{32}$ \\
\hline
\end{tabular}

${ }^{22}$ Mellers, 210.

${ }^{23}$ Mellers, 211.

${ }^{24}$ Mellers, 211.

${ }^{25}$ Mellers, 212.

${ }^{26}$ Etter, 144.

${ }^{27}$ Etter, 144.

${ }^{28}$ Consisting of "pentatonic organum in D minor, the metre trudging, and with the familiar motif of rising fourth lifting to fifth on trombone and viola." Mellers, 216.

${ }^{29}$ Mellers. 216.

${ }^{30}$ Etter, 144.

${ }^{31}$ Etter, 144.

${ }^{32}$ Etter, 144. 
Table 4.2 Borrowing in Sancta Civitas

\begin{tabular}{c|c} 
Sancta Civitas's Musical elements & $\begin{array}{c}\text { Other works or musical elements related to } \\
\text { Sancta Civitas }\end{array}$ \\
\hline 'The Rider,' named Faithful and True & $\begin{array}{c}\text { Bunyan's Pilgrim } \\
\text { 'Glory and honour' }\end{array}$ \\
\hline $\begin{array}{c}\text { The juxtaposition of the G minor 'fall' } \\
\text { with E major 'paradise' }\end{array}$ & $\begin{array}{c}\text { "Inversion the famous fall motif in the arioso of } \\
\text { Orfeo's Messenger, at precisely the same } \\
\text { pitches"35 }\end{array}$
\end{tabular}

Table 4.3 Borrowing in Dona Nobis Pacem

\begin{tabular}{c|c} 
Dona Nobis Pacem's musical element & $\begin{array}{c}\text { Job's element related to Dona } \\
\text { Nobis Pacem }\end{array}$ \\
\hline 'Mother's entreaties' motif & Blessing-curse motif ${ }^{36}$
\end{tabular}

As shown in the tables, borrowings in Hodie are more systematic and diverse than in other works. Various musical elements and styles are borrowed from his other works regardless of genre.

With the combination of biblical and non-biblical texts in Hodie, the borrowing becomes more complicated by different figurations.

\footnotetext{
${ }^{33}$ Mellers, 138.

${ }^{34}$ Mellers, 140.

${ }^{35}$ Mellers, 139.

${ }^{36}$ Mellers, 173.
} 


\section{Conclusion}

The music of Vaughan Williams reflects his thoughts and beliefs as well as his reactions to his social environment. Through the choice of texts for the large choral works specific messages were conveyed, and through the combination of biblical and non-biblical sources new meanings recreated for his listeners. Although Vaughan Williams drew on the musical styles of previous generations, he developed his own unique style based on a blend of tonality and modality. By borrowing diverse musical elements from his own works as well as those of other composers, he expressed his ideas systematically and often symbolically. With innovative compositional techniques, dramatic orchestration, and a highly developed use of recurring musical ideas, Hodie emerges as a significant choral work of the mid-twentieth century. 


\section{Bibliography}

Academy of American Poets. “John Milton.” Poets. Org. http://www.poets.org/poet.php/prmPID/707 [accessed July 26, 2013].

Academy of American Poets. "Thomas Hardy." Poets. Org. http://www.poets.org/poet.php/prmPID/707 [accessed August 5, 2013].

Adams, Byron, "Scripture, Church, and Culture: Biblical Texts in the Works of Ralph Vaughan Williams." Vaughan Williams Studies. New York: Cambridge University Press, 1996: 99117.

Archivescanada.ca. "Colles, Henry Cope, 1879-1943.” Canadian Council of Archives. http://archivescanada.accesstomemory.org/colles-henry-cope-1879-1943 [accessed September 23, 2013].

Barnicle, Stephan P. "Polychoral Concerts: Sound in the Round." Music Educators Journal 66, no. 3 (November 1979): 44-47, 86-87.

Borton, Allen L. "Ralph Vaughan Williams's Hodie at Forty.” Choral Journal 35, no. 5 (December 1994): 17-20.

Burn, Andrew. Dona Nobis Pacem and Sancta Civitas. CD Booklet. Naxos: Canada. 2010.

Connock, Stephen. "The Life of Ralph Vaughan Williams." The Ralph Vaughan Williams Society. http://www.rvwsociety.com/bio_expanded.html [accessed June 5, 2013].

Corns, Thomas. "'On the Morning of Christ's Nativity', 'Upon the Circumcision' and 'The Passion'" in A Companion to Milton. Ed. Thomas Corns. Oxford: Blackwell Publishing, 2003.

Dickinson, A. E. F. “Obituaries,” Tempo, no. 49 (Autumn 1958): 33-5.

—. "Ralph Vaughan Williams." The Musical Quarterly 45, no. 1 (January 1959): 1-7.

—. Vaughan Williams. London: Faber\&Faber, 1963: 373.

Etter, Paul James. 'Ralph Vaughan Williams's 'Hodie': An Analysis and Performance Guide for the Choral Conductor.” Ph.D., Texas Tech University, 2002. In ProQuest Dissertations and Theses, http://search.proquest.com/pqdtft/docview/305482745/13E44A9D9F9519F22FB/2?accoun $\underline{\mathrm{tid}=2837}$ [accessed May 26, 2013]. 
Fancher, J. R. "Hodie (This Day) by Ralph Vaughan Williams." The Naperville Chorus. http://www.napervillechorus.org/program_notes/pn_200404_HodieRVW.html [accessed June 5, 2013].

Frogley, Alain. "Constructing Englishness in Music: National Character and the Reception of Ralph Vaughan Williams." Vaughan Williams Studies. 1-22. New York: Cambridge University Press, 1996.

- Vaughan Williams: Hodie (A Christmas Cantata). CD Booklet. Musical Heritage: London. 1990.

Heffer, Simon. Vaughan Williams. Boston: Northeastern University Press, 2001.

Howes, Frank Stewart. The Music of Ralph Vaughan Williams. London: Oxford University Press, 1954.

Kennedy, Michael. A Catalogue of the Works of Ralph Vaughan Williams. $2^{\text {nd }}$ ed. London: Oxford University Press, 1982.

—. The Works of Ralph Vaughan Williams. London: Oxford University Press, 1964.

- Review of Ralph Vaughan Williams: A Discovery of His Music by Simona Pakenham. The Musical Times 98, no. 1375 (September 1957): 486-7.

—. "Vaughan Williams, Ralph." The Oxford Companion to Music. Oxford Music Online. Oxford University Press. http://www.oxfordmusiconline.com/subscriber/article/opr/t114/e7076 [accessed May 26, 2013].

—. "Vaughan Williams at Eighty-Five." The Musical Times 98, no. 1376 (October 1957): 545-6.

Kimmel, William. "Vaughan Williams's Choice of Words." Music \& Letters 19, no. 2 (April 1938): 132-142.

Lunn, John E, and Ursula Vaughan Williams. Ralph Vaughan Williams: A Pictorial Biography. London: Oxford University Press, 1971.

Matthews, David. Review of Vaughan Williams and the Vision of Albion by Wilfrid Mellers. Tempo, no. 171(December 1989): 39-40.

Mellers, Wilfrid. "Vaughan Williams, Hodie." The Musical Times 107, no. 1477 (March 1966): 226.

.Vaughan Williams and the Vision of Albion. Illminster: Albion Music, 1997. 
Oswell, Michelle. "The $17^{\text {th }}$ Lute Song Composers." The Printed English Lute Song in $17^{\text {th }}$ century England. http://www.pages.drexel.edu/ mlo26/composers.html [accessed August 6, 2013].

Ottaway, Hugh and Alain Frogley. "Vaughan Williams, Ralph." Grove Music Online. Oxford Music Online. Oxford University Press. http://www.oxfordmusiconline.com/subscriber/article/grove/music/42507 [accessed May 26, 2013].

Ottaway, Hugh. Review of $R$. V. W.: A Biography of Ralph Vaughan Williams by Ursula Vaughan Williams and The Works of Ralph Vaughan Williams by Michael Kennedy. The Musical Times 106, no. 1464 (February 1965):110-111.

. Review of Sancta Civitas; Benedicite by Vaughan Williams. The Musical Times 110, no. 1511 (January 1969): 44-45.

Pike, Lionel. "Tallis: Vaughan Williams: Howells: Reflections on Mode Three.” Tempo, no. 149 (June 1984): 2.

Queen, James L. "Ralph Vaughan Williams: Hodie and Fantasia on Christmas Carols." Choral Journal (September 2008): 102-3.

Steinberg, Michael. Choral Masterworks: A Listener's Guide. New York: Oxford University Press, 2005.

The Milton Reading Room. "On the Morning of Christs Nativity Compos'd 1629." Dartmouth College. http://www.dartmouth.edu/ milton/reading_room/nativity/ [accessed July 26, 2013].

Ulrich, Homer. A Survey of Choral Music. New York: Harcourt Brace Jovanovich, Inc., 1973: 206.

"Vaughan Williams, Ralph.” The Oxford Dictionary of Music, Rev. 2nd ed. Oxford Music Online. Oxford University Press. http://www.oxfordmusiconline.com/subscriber/article/opr/t237/e10634 [accessed May 26, 2013].

Vaughan Williams, Ralph. Dona Nobis Pacem. Vocal Score. London: Oxford University Press. 1936.

- Hodie (This day). Pianoforte arranged by Roy Douglas, Oxford: Oxford University Press. 1954.

—. Hodie (This day). Full Score. London: Oxford University Press. 1967.

—. Sancta Civitas. Vocal Score.G. Schirmer: New York. 1925. 
- Vaughan Williams on Music. Edited by David Manning. Oxford: Oxford University Press, 2008.

Vaughan Williams, Ursula. R.V.W.: A Biography of Ralph Vaughan Williams. London: Oxford University Press, 1964.

—. "Ralph Vaughan Williams and His Choice of Words for Music." Proceedings of the Royal Musical Association 99 (1972): 81-9.

Willetts, Pamela Joan. Ralph Vaughan Williams, 1872-1958: A Guide to the Centenary Exhibition at the British Museum, 29 Sept. to 15 Dec. 1972. London: British Museum, 1972.

—. "The Ralph Vaughan Williams Collection." The British Museum Quarterly 24, no. 1 (August 1961): 3-11.

Woodhouse, A. S. P. and Douglas Bush, eds. A Variorum Commentary on The Poems of John Milton, Vol II. New York: Columbia University Press, 1972. 